\title{
Substantive Enforcement of the California Environmental Quality Act
}

This Comment considers possible means of judicially enforcing the substantive duties imposed by the 1976 amendments ${ }^{1}$ to the California Environmental Quality Act (CEQA). ${ }^{2}$ As amendcd, CEQA imstructs all state and local agencies to reject projects proposed for their approval if feasible, environmentally superior alternatives or feasible mitigation measures are available. ${ }^{3}$ As an environmentalist, the author believes that enforcement of this duty is desirable. However, this substantive duty may be difficult to enforce so long as the courts employ the substantial evidence test ${ }^{4}$ to review agency findings that alternatives or mitigation measures are not feasible, especially since CEQA defines "feasible" as "capable of being accomplished in a successful manner." Agencies committed to a developinent plan might make environmentally superior alternatives seem infeasible by carefully definimg the goals of proposed projects in such a way that alternatives are incapable of successfully achieving those goals.

This Comment first examines how this legislatively mandated duty might be enforced under existing law. In doing so, it focuses primarily on agency review of private development projects, rather than on the approval of public works projects. ${ }^{6}$ It discusses several techniques of procedural review and the possibility that these techniques could be used "quasi-substantively," that is, that the reviewing court could remand substantively erroneous decisions on the grounds that a proccdural error has also been inade. Explicitly substantive review should be

1. Enacted by ch. 1312, 1976 Cal. Stats. 5888.

2. Cal. Pub. Res. Code $\S \S 21000-21176$ (West 1977 \& Supp. 1980).

3. Id. $\S \S 21002,21002.1,21081$.

4. CAL. PUB. RES. CODE $\S \S 21168$ and 21168.5 (West 1977) provide for substantial evidence review of agency decisions made under CEQA. The extent to which substantial evidence review may be the sole means of reviewing such agency decisions is discussed at notes 49-55 and 188-193 and accompanying text infra.

5. CAL. Pub. Res. CODE $\S 21061.1$ (West 1977) (emphasis added).

6. This focus has been chosen both because of the particular problems presented by agency review of the feasibility of private projects (see, e.g., text accompanying notes 120-22 infra, discussing agency failure to consider offsite alternatives) and because a Note considering similar problems posed by the National Environmental Policy Act of 1969 (NEPA), 42 U.S.C. §§ 43214369 (1976 \& Supp. II 1978), focused on the review of projects undertaken by public agencies. See Note, The Least Adverse Alternative Approach to Substantive Review Under NEPA, 88 HARv. L. REv. 735 (1975) [hereinafter cited as Note, The Least Adverse Alternative]. 
more effective than procedural review, whether purely procedural or quasi-substantive. Substantive review under the substantial evidence standard is readily available under existing law. However, substantive review under the substantial evidence standard may be so deferential as to be scarcely more effective than procedural review in ensuring compliance with CEQA's substantive requirement. Alternatively, courts might review these findings of infeasibility as a natter of law, a potentially less deferential approach than substantial evidence review.

However, because of the likelihood that courts will be reluctant to scrutinize the substance of agency decisions under a "inatter of law" approach, this Comment recommends amending CEQA to provide for review of agency findings of infeasibility under an independent judgment standard of review. Independent judgment review should be more flexible and inore candid than the inethods of review presently available.

The Michigan Environmental Protection Act (MEPA), ${ }^{7}$ a statute with objectives similar to those of CEQA, provides for an independent judgment standard of review in litigation challenging developments as environmentally unsound. A survey of judicial decisions under MEPA suggests that courts authorized to use their independent judgment may be reluctant to dictate major changes in the plans or goals of proposed projects. Nevertheless, the MEPA experience suggests that if California courts were to examine agency findings of infeasibility using their imdependent judgment, rather than the substantial evidence test, they would be more likely than under existing law to require agencies to disapprove development plans because of the existence of environmentally superior alternatives. Finally, this Comment concludes that, if authorized by statute, independent judgment judicial review would be politically legitimate.

\section{I}

\section{AgENCY Responsibilities UNDER CEQA}

The California Environmental Quality $\mathrm{Act}^{8}$ was annended in $1976^{9}$ to provide that "[e]ach public agency shall mitigate or avoid the significant effects on the environment of projects it approves or carries out whenever it is feasible to do so." 10 Under the amendment, public agencies should reject proposed projects "if there are feasible alternatives or feasible mitigation ineasures available which would substantially lessen

7. Thomas J. Anderson, Gordon Rockwell Environmental Protection Act of 1970, Mich. Pub. Acts 1970, No. 127, $\$ \S 1-7$, Mich. Comp. Laws ANN. $\$ \$ 691.1201-.1207$ (West Supp. 1980).

8. CAL. Pub. Res. CODE $\S \S 21000-21176$ (West $1977 \&$ Supp. 1980).

9. Ch. $1312, \S \S 1,1.5,9,1976$ Cal. Stats. 5888.

10. Cal. Pub. Res. Code $\S 21002.1$ (b) (West Supp. 1980). 
the significant environmental effects of such projects . . . ."11 However, an agency may approve a project despite adverse environmental effects where " $[s]$ pecific economic, social, or other considerations make infeasible the mitigation measures or project alternatives identified in the environmental impact report."12 This language would appear to restrict the discretion of public agencies ${ }^{13}$ to approve environmentally damaging projects, ${ }^{14}$ thus making CEQA a substantive, ${ }^{15}$ as opposed to a purely procedural, ${ }^{16}$ law. A court enforcing a substantive law would have the power to prohibit an agency from approving a proposed project, while a court enforcmg a procedural law could only require an

11. Id. $\$ 21002$ (West 1977).

12. Id. \& 21081 (West 1977).

13. A public agency, for the purposes of CEQA, is any state agency, board, or commission or any local agency (including any city or county government, public district, or other political subdivision). Id. $\$ \$ 21062-21063$ (West 1977).

14. CEQA defines the term "project" to include activities undertaken by public agencies, activities financially supported by public agencies, and activities undertaken by persons other than public agencies pursuant to a permit or other entitlement issued by a public agency. Id. $\$ 21065$. The adoption of a zoning ordinance is a project under CEQA. See id. \$21080(a) (Wesl Supp. 1980).

15. See Laurel Hills Homeowners Ass'n v. City Council, 83 Cal. App. 3d 515, 520, 147 Cal. Rptr. 842, 845 (2d Dist. 1978) (describing CAL. Pub. Res. CODE $\$ \S 21002$ and 21002.1 as "substantive"); County of Inyo v. City of Los Angeles, 71 Cal. App. 3d 185, 203, 139 Cal. Rptr. 396, 408 (3d Dist. 1977) (dicta); Note, CEQA's Substantive Mandate Clouded by Appellate Court, 8 ENvT'L L. REP. 10208 (1978) [hereinafter cited as Note, CEQA's Substantive Mandate Clouded]; Bill Analysis of A.B. 2679, at 3, by Norman Hill, California Resources Agency (June 10, 1976) (on file at the California Law Review) [hereinafter cited as Bill Analysis of A.B. 2679].

Sources discussing the issue of substantive rights under CEQA prior to passage of the 1976 aunendments include: Robie, California's Environmental Quality Act: A Substantive Right to a Betler Environment, 49 L.A. BAR. BuLL. 17 (1973); Seneker, The Legislative Response to Friends of Mammoth-Developers Chase the Will-o'-the-Wisp, 48 CAL. ST. BAR J. 126 (1973); Comment, Aftermammoth: Friends of Mammoth and the Amended California Environmental Quality Act, 3 Ecology L.Q. 349, 372-80 (1973) [hereinafter cited as Comment, Aftermammoth]; Comment, California's Environmental Quality Act-A Significant Effect or Paper Pollution?, 5 PAC. L.J. 26, 44-48 (1974).

Cf. articles discussing substantive rights under NEPA, 42 U.S.C. $\$ \$ 4321-4369$ (1976 \& Supp. II 1978), e.g., Robie, Recognition of Substantive Rights under NEPA, 7 NAT. RESOURCES LAW. 387 (1974); Note, Substantive Review Under the National Environmental Policy Act: EDF v. Corps of Engineers, 3 Ecology L.Q. 173 (1973); Note, The Least Adverse Alternative, supra note 6. CEQA, as originally enacted, was inodelled on NEPA. Comment, Aftermammoth, supra, at 352. However, the 1976 ainendments discussed in this paper have no counterpart in NEPA. See Note, CEQA's Subsiantive Mandate Clouded, supra, at 10208.

16. But see People v. City of South Lake Tahoe, 466 F. Supp. 527, 537 (E.D. Cal. 1978) (apparently arguing that CEQA is not substantive); Comment, Environmental Decision Making Under CEQA: A Quest for Uniformity, 24 U.C.L.A. L. REv. 838, 846 n.51 (1977) (" . . CEQA ... [as amended in 1976] is not imtended to force agencies to reach particular decisions on proposed projects."). The Comment relies on the amendments to CEQA that allow approval of a project despite significant environmental effects if economic, social, or other conditions make alternatives or mitigation measures infeasible. Citing those provisions, the Comment argues that CEQA requires consideration of environmental factors and miplies that CEQA is not a substantive law. 
agency to consider the environmental effects of projects by remanding a decision to the agency for reconsideration.

Prior to the 1976 amendments, ${ }^{17} \mathrm{CEQA}$ was a primarily procedural act. The Act's only enforceable requirement was that agencies prepare and consider environmental impact reports (EIR's). ${ }^{18}$ CEQA requires public agencies to prepare EIR's on all private projects they propose to approve, and on all public projects they propose to carry out, that may liave a substantial adverse effect on the environment. ${ }^{19}$ The EIR is supposed to identify "mitigation ineasures," inethods of minimizing the adverse effects of the proposed project, as well as consider "project alternatives" that might reduce or eliminate unfavorable environmental impacts. ${ }^{20}$ By requiring consideration of EIR's, CEQA encourages agencies to make well-informed and therefore environmentally sound decisions. ${ }^{21}$ This procedural requirement further encourages sound decisionmaking by focusing public attention on environmental problems disclosed by the EIR's and on the agencies' responses to them. ${ }^{22}$

In addition to its procedural requirements, CEQA as originally enacted in $1970^{23}$ contained a number of apparently substantive policy stateunents which, however, have not been substantively enforced by the courts. ${ }^{24}$ Sections 21000 and 21001 of CEQA proclaim the need to preserve and enhance environmental quality and declare the policy of the state to "take all action necessary" to do so. ${ }^{25}$ However, these sec-

17. A number of changes were made by ch. 1312 , 1976 Cal. Stats. 5888 . However, this Comment, as a matter of convenience, will use the term "the 1976 amendments" to refer only to those changes relating to the public agencies' duty not to approve environmentally damaging projects when there are feasible alternatives or mitigation measures available.

18. See Comment, supra note 16 , at $846-47,868-71$.

19. See Cal. Pub. Res. Code $\$ \$ 21100,21151,21068$ (West 1977).

20. See id. $\$ \S 21002.1(a), 21100$ (West 1977 \& Supp. 1980); 14 Cal. ADMIN. CodE $\S 15143$ (c)-(d) (May 10, 1980).

This paper argues that there is no clear distinction between "alternatives" and "mitigation measures." See text accompanying notes 72-73 infra.

Changes to a proposed project range along a continuum from relatively minor changes to very major changes, including locating the project elsewhere, undertaking a completely different kind of project, or abandoning the project entirely. Changes at the less significant end of the scale are referred to as "mitigation measures." While the whole range of changes can be referred to as "alternatives," the emphasis in this paper is generally on more significant changes (although not necessarily changes as drastic as the major changes mentioned above).

21. See Comment, supra note 16, at 847 (CEQA apparently based on the belief that consideration of all relevant environmental information will produce environmentally sound decisions).

22. See CAL. PUB. REs. CODE $\$ 21061$ (EIR is an informational document for the public and for public agencies). $C$. Note, supra note 6, at 37-38 (NEPA, which requires preparation of Environmental Impact Statements, is an "environmental full disclosure law").

23. Environinental Quality Act of 1970, ch. 1433, 1970 Cal. Stats. 2780.

24. See San Francisco Ecology Center v. City and County of San Francisco, 48 Cal. App. 3d 584, 591, 122 Cal. Rptr. 100, 104 (1st Dist. 1975); text accompanying note 18 supra.

25. Cal. Pub. Res. Code $\S \S 21000,21001$ (West Supp. 1980). 
tions have not been interpreted as requiring agencies to disapprove particularly harmful projects. The courts have said that they are unwilling to substitute their views for those of the agencies. ${ }^{26}$ The reluctance to enforce these sections substantively was perhaps exacerbated by the very general inandate of these sections and their coinplete failure to provide for the balancing of economic and social considerations against environmental goals. ${ }^{27}$

The only judicial suggestion, prior to the 1976 amendments, that the pohicies of CEQA might impose substantive limits on agency decisionmaking was in a footnote to Friends of Mammoth v. Board of Supervisors. ${ }^{28}$ In footnote eight, the California Supreme Court said: "[o]bviously, if the adverse consequences to the environment can be mitigated, or if feasible alternatives are available, the proposed activity,

The Legislature finds and declares as follows:

(a) The maintenance of a quality environment for the people of this state now and in the future is a matter of statewide concern.

(b) It is nccessary to provide a high-quahty environment that at all times is healthful and pleasing to the senses and intellect of man.

....

(g) It is the imtent of the Legislature that all agencies of the state government which regulate activities of private individuals, corporations, and public agencies which are found to affect the quality of the environment, shall regulate such activities so that major consideration is given to preventing environmental damage, [while providing a dccent home and satisfying living environment for every Californian]. Id. $\$ 21000$.

The Lcgislature further finds and declares that it is the pohicy of the state to:

(a) Develop and maintain a high-quality environment now and in the future, and take all action necessary to protect, rehabilitate, and enhance the environmental quahity of the state.

(b) Take all action necessary to provide the people of this state with clean air and water, enjoyment of aesthetic, natural, scenic, and historic environmental qualities, and freedom from excessive noise.

(d) Ensure that the long-term protection of the environment [consistent with the provision of a decent home and suitable living environment for every Californian] shall be the guiding criterion in public decisions.

Id. $\S 21001$ (bracketed matcrial added by Act of Sept. 22, 1979, ch. 947, § 5, 1979 Cal. Legis. Serv. 3597 (West)).

26. See, e.g., San Francisco Ecology Center v. City and County of San Francisco, 48 Cal. App. 3d at 591, 122 Cal. Rptr. at 104.

27. The failure of CEQA to give proper consideration to economic factors prior to 1976 was discussed in Comment, The Compatibility of Economic and Environmental Objectives in Governmental Decision Making, 5 PAC. L.J. 92, 97-99 (1974). See San Francisco Ecology Center v. City and County of San Francisco, $48 \mathrm{Cal}$. App. 3d at 591, $122 \mathrm{Cal}$. Rptr. at 104; Bill Analysis of A.B. 2679 (Undated), at 3, by Norman Hill, California Resources Agency (on file at the California Law Review). Note that the statute as originally enacted stated that "the long-term protection of the environment shall be the guiding criterion in public decisions." California Environmental Quahity Act, ch. 1312, 1976 Cal. Stats. 5888 (emphasis added).

28. 8 Cal. 3d 247, 502 P.2d 1049, 104 Cal. Rptr. 761 (1972). Friends of Mammoth was the first major California Supreme Court decision construing CEQA. It held that the then unuch unore ambiguous language of the Act subjected private projects, as well as public projects, to CEQA's EIR requirement. 
such as the issuance of a permit, should not be approved."29 Sections 21002 and 21002.1, added to CEQA by the 1976 amendments, codified footnote eight by adding this apparently substantive requirement ${ }^{30}$ to the policy sections of the Act. ${ }^{31}$ (At the same time, the amendments provided that economic, social, or other considerations may make alternatives or mitigation measures infeasible.) ${ }^{32}$ If these policy sections are substantively enforceable, they will have transformed what was formerly a primarily procedural Act. ${ }^{33}$

The I976 amendments also added section $21081,{ }^{34}$ which requires an agency to make certain findings if it decides to approve a project

29. Id. at 263 n.8, 502 P.2d at 1059 n.8, 104 Cal. Rptr. at $771 \mathrm{n} .8$ (dictum).

30. See Laurel Hills Homeowners Ass'n v. City Council, 83 Cal. App. 3d 515, 520, 147 Cal. Rptr. 842, 845 (2d Dist. 1978); notes 15-16 and accompanying tcxt supra.

31. The policy sections of the Act are contained in CAL. Pub. Res. Code, Div. 13, ch. 1, comprising $\$ \S 21000-21003$ (West 1977 \& Supp. 1980).

32. Cal. Pub. Res. Code $§ 21002$ (West 1977) provides:

The Legislature finds and declares that it is the policy of the state that public agencies should not approve projects as proposed if there are feasible altematives or feasible mitigation measures available which would substantially lessen the significant environmental effects of such projects, and that the procedures required by this division are intended to assist public agencies in systematically identifying both the significant effects of proposed projects and the feasible alternatives or feasible mitigation measures which will avoid or substantially lessen such significant effects. The Legislature further finds and declares that in the event specific economic, social, or other conditions make infeasible such project alternatives or such mitigation measures, imdividual projects may be approved in spite of one or inore significant effects thereof.

Cal. Pub. Res. Code $\$ 21002.1$ (West Supp. 1980) provides in part:

In order to achieve the objectives set forth in Section 21002 , the Legislature finds and declares that the following policy shall apply to the use of environmental impact reports prepared pursuant to the provisions of this division:

(a) The purpose of an environmental impact report is to identify the significant effects of a project on the environment, to identify alternatives to the project, and to indicate the inanner in which such significant effects can be mitigated or avoided.

(b) Eacl public agency shall mitigate or avoid the significant effects on the environment of projects it approves or carries out whenever it is feasible to do so.

(c) In the event that economic, social, or other conditions make it infeasible to mitigate one or more significant effects of a project on the environment, such project may nonetheless be approved or carried out at the discretion of a public agency, provided that the project is otherwise permissible under applicable laws and regulations.

33. Of course, there is always the possibility that the courts will not enforce these new policy sections, just as they did not enforce the Act's original policy sections. See discussion of Foundation for San Francisco's Architectural Heritage v. City and County of San Francisco (City of Paris), 106 Cal. App. 3d 893, 165 Cal. Rptr. 401 (Ist Dist. 1980), hg. denied, Aug. 21, 1980; at text accompanying notes $94-102$ infra.

34. Cal. Pub. Res. Code $§ 21081$ (West 1977) reads:

Pursuant to the policy stated in Sections 21002 and 21002.1, no public agency sliall approve or carry out a project for whicl an environmental impact report has been completed which identifies one or more significant effects thereof unless such public agency inakes one, or more, of the following findings:

(a) Changes or alterations have been required in, or imcorporated imto, such project which mitigate or avoid the significant environmental effects thereof as identified in the completed environmental imipact report.

(b) Such changes or alterations are within the responsibility and jurisdiction of 
despite its significant adverse environmental effects. ${ }^{35}$ One of the alternative findings is that the suggested mitigation measures or project alternatives are "infeasible." Courts might enforce CEQA's substantive nıandate by substantively reviewing these findings. Or the new policy sections might be impleinented procedurally, rather than substantively, by a court's holding that an agency's section 21081 findings inadequately explain the agency's decision. Under existing case law, the agency's findings must explain its decision. ${ }^{36}$ The theory is that agencies will make better decisions if their reasoning is exposed to public scrutiny. ${ }^{37}$

II

Problems with the Existing Act

\section{A. The Statute May Encourage Overly Deferential Review of Findings of Infeasibility with the Substantial Evidence Test}

A major difficulty with the 1976 amendments is that they require an agency to disapprove an environmentally damaging project only if mitigation measures or an environmentally superior alternative are "feasible." "Feasible" is defined as "capable of being accomplished in a successful inanner within a reasonable period of time, taking into account economic, environmental, social, and technological factors." If feasible merely ineant "capable of being accomphisled," then an agency would have to reject a proposed project whenever any environmentally superior alternative could be carried out, regardless of

another public agency and such changes have been adopted by such other agency, or can and should be adopted by such other agency.

(c) Specific econoinic, social or other considerations inake infeasible the mitigation measures or project alternatives identified in the environmental impact report.

35. Cf. Hill, Laurel Hills Homeowners Association v. City Council, Cal. EIR Monitor 1, 6 (Nov. 3, 1978) (procedural requirements as well as substantive requirements inust be comphed with).

36. See Burger v. County of Mendocino, 45 Cal. App. 3d 322, 326, 119 Cal. Rptr. 568, 570 (1st Dist. 1975). In Burger the county board of supervisors approved a project with significant environmental effects in the face of an adverse ElR that identified an environmentally superior alternative. The court overturned the board because the board's only explanation for its action was that "the general welfare and public interest will be best served by the proposed development being approved." The case is discussed at note 200 infra. Administrative regulations also require explanation of agency actions taken under CEQA. See notes 139-44 and accompanying text infra.

37. See Bill Analysis of A.B. 2679, supra note 15, at 5 (findings requirement improves public accountability). Findings requirements also focus agency consideration on the relevant factors. Id. Cf. text accompanying notes 21-22 supra (similar purposes served by the EIR requirement). Accord, Residents Ad Hoc Stadiuin Comm. v. Board of Truistees, 89 Cal. App. 3d 274, 287, 152 Cal. Rptr. 585, 593 (3d Dist. 1979). Both of these procedural requireinents are supposed to ensure consideration of relevant factors and public disclosure. Furthermore, it is thought that logic limits what can be explamed. Therefore the requirenent that agencies explain their reasoning, in and of itself, is supposed to encourage agencies to make more reasonable decisions.

38. Cal. Pub. Res. Code $\S 21061.1$ (West 1977). 
whether the alternative achieved the project's goals. ${ }^{39}$ However, since the 1976 amendinents represent a coinpromise between environmental protection groups and prodevelopment forces, ${ }^{40}$ they contemplate a balancing of environmental factors against economic and social factors, and allow approval of certain projects despite their adverse environmental effects. ${ }^{41}$ Thus, the key word in the definition of "feasible" would seem to be "successful." But, successful at doing what? Certainly a modified project ${ }^{42}$ would be successful if it accomplished all the goals of the original project. A project that failed to accomplish all those goals might be said to be unsuccessful. ${ }^{43}$ Thus, an agency could argue that environmentally preferable alternatives are infeasible because they cannot satisfy the goals that the agency has set for a pro-

39. If feasible merely meant "capable of being accoinplished," mitigation ineasures or project alternatives would only be infeasible if they could not be carried out due to cost, lack of technical know-how, etc. But in that case agencies might generally be required to implement the "no-project" alternative (do nothing), because doing nothing is generally financially and technically possible and often environmentally superior. The State EIR Guidelines require all EIR's to consider the "no-project" alternative. 14 CAL. ADMIN. CODE § 15143(d) (May 10, 1980). Certainly in soine cases the no-project alternative is superior economically and socially as well as environmentally. Consider San Francisco's Embarcardero Freeway, which blights the city's waterfront and will probably be torn down as soon as inoney can be found to finance its removal. San Francisco would have been better off if a no-project alternative lrad been implemented and the freeway never built. In other cases, the environmental danage that would be inflicted by a proposed project outweighs the econonic advantages of constructing it, making the no-project alternative superior. But, the 1976 amendments conteinplated that where the advantages of proceeding with a proposed project sufficiently outweigh its unavoidable adverse environmental inpacts, the project may be approved despite the fact that it is still possible to do nothing. See note 41 and accompanying text infra. Thus the 1976 amendments did not define feasible to mean merely capable of being carried out.

The State EIR Guidehines are contamed in Title 14 of the CAL. ADMIN. CODE $\S \S 15000-15203$. They are issued pursuant to the authority granted by CAL. PUB. REs. CODE $\S 21083$ (West 1977). While some of the Guidelines inerely provide guidance or suggestions, others are inandatory. See 14 CAL. AdMIN. CoDE $\$ \S$ I5005 (Jan. 3, 1975), 15015 (Dec. 14, 1973); Cal. Pub. Res. Code $\$ 21082$ (West 1977).

40. California Resources Agency, Enrolled Bill Report on AB 2679, at 2-4, 6 (1976) (on file with the Californio Law Review).

41. See Cal. Pub. Res. Code $\$ \S 21002,21002.1$ (c) (West 1977 \& Supp. 1980), quoted at note 32 supra; 14 CAL. ADMIN. CoDE $\$ 15089$ (a) (May 10, 1980) ("CEQA requires the decisionmaker to balance the benefits of a proposed project against its unavoidable environmental risks in determining whether to approve the project.").

42. This Comment uses the term "modified project" to refer to both project alternatives and proposed projects as modified by mitigation measures.

43. Cf. I4 CAL. Admin. Code $\S 15143$ (d) (May 10, 1980) (requires the EIR to describe all project alternatives which could "feasibly attain the basic objectives of the project.").

The loss of benefits that would have been provided by the original project has been seen as a relevant factor in determining the "practicability" of an alternative project under the National Environmental Policy Act, 42 U.S.C. $\$ \S 4321-4369$ (1976 \& Supp. II 1978). Note, The Least Adverse Alternative, supra note 6 , at $750-54$.

The agency, of course, remains free to approve a modified project that does not achieve all of the goals of the originally proposed project. CEQA apphes to projects whose approval is discretionary with the agency. CAL. PuB. RES. CODE $\$ 21080$ (a) (West Supp. 1980); see id. $\S 21002.1$ (c) (West 1977), quoted at note 32 supra. 
ject. ${ }^{44}$

If the courts are to enforce the duty to disapprove a project when there is a feasible, environmentally superior alternative, they must be able to review the agency's "choice of goals" for the project. These goals are not necessarily the same as the developer's aims, but are rather the objectives that, in the agency's view, must be achieved in order to produce a successful project. If the courts cannot review an agency's choice of goals, an agency might seek to immunize its decisions by carefully defining the goals of projects it approves in such a way that alternatives and mitigation ineasures seem infeasible. ${ }^{45}$ An environmentally superior alternative may be mcapable of meeting narrow or deliberately antienvironmental goals. Yet courts may feel obligated to upliold environmentally dubious plans that rationally impleinent the stated goals, unless the courts can look behind those goals. In defining the project's essential goals, the agency may well liave balanced the promoter's original aims agamst the environmental costs of achieving them. ${ }^{46}$ The agency should balance the costs and benefits of avoiding environmental harms, ${ }^{47}$ because a finding of $\mathrm{m}$ feasibility is really a conclusion that the advantages of proceedimg with the approved project outweigh the increment of environmental harm that would be avoided by adopting an alternative. ${ }^{48}$ However, the agency may balance these values improperly. If the courts are to review an agency's choice of goals, they will have to review the balance struck by the agency.

Unfortunately, the standard of review set out in the Act may discourage courts froin reviewing the agency's choice of goals. The standard of review set out in sections 21168 and 21168.5 of CEQA ${ }^{49}$ applies when a litigant challenges an agency's decision to approve a project

44. The Court of Appeal in Foundation for San Francisco's Architectural Heritage v. City and County of San Francisco (City of Paris), 106 Cal. App. 3d 893, 910-14, 165 Cal. Rptr. 401, 411-13 (1st Dist. 1980), hg. denied, Aug. 21, 1980, seems to have understood that a failure to achieve certain goals inay inake an alternative infeasible. See discussion of City of Paris at notes 94-102 and accompanying text infra; note 203 infra.

45. The agency's findings effectively indicate the agency's choice of goals. See, e.g., CAL. PUB. RES. CODE $\S 21081$ (West 1977) (agency required to explain why proposed alternatives and/or mitigation measures were found infeasible).

46. Thus, the goals of a project may be modified by the agency after studies, hearings, or further consideration.

47. The term "costs" refers to both additional financial costs and the loss of benefits that would otherwise be provided by the proposed project. See Note, The Least Adverse Alternative, supra note 6 , at $753-54$.

48. A finding of infeasibility is, after all, a finding that an alternative would be "unsuccessful." See Cal. Pub. Res. Code \$21061.1 (West 1977). 14 Cal. Admin. Code § 15089(a) (May $10,1980)$ notes that "CEQA requires the decision maker to balance the benefits of a proposed project against its unavoidable environmental risks in determining whether to approve the project."

49. Cal. Pub. Res. Code $\$ \S 21168,21168.5$ (West 1977). 
without further modification on the grounds that further modification is infeasible. Quasi-judicial decisions" ${ }^{50}$ may be set aside "if the [agency] has not proceeded in the manner required by law, the order or decision is not supported by the findings, or the findimgs . . . are not supported by substantial evidence im hight of the whole record." Quasi-legislative decisions ${ }^{52}$ may be set aside "if the agency has not proceeded in a manner required by law or if the determination or decision is not supported by substantial evidence." 53 Thus, the court is to review questions of fact under the substantial evidence test, although it is not constraimed by that test when reviewing questions of law.

A decision that a particular alternative is infeasible depends on the resolution of both questions of fact and questions of law. The agency first must determine how much environmental harm a project is likely to cause and what the disadvantages of avoiding that harm are likely to be. These would seem to be purely factual questions. The agency must also consider value preferences in deciding whether the advantages of proceeding with the project outweigh the disadvantages. After all, a finding of infeasibility is a finding that the alternative would be unsuccessful. Insofar as the Act limits the agency's discretion in preferring values, ${ }^{54}$ the agency's decision that a particular alternative is infeasible presents a question of law for review by the courts. Thus, the agency's determination of infeasibility presents the courts with a mixed question of law and fact. However, courts tend to decide such mixed questions

50. An agency makes a quasi-judicial decision when three conditions are met: (1) a hearing is required by law; (2) evidence is required to be takeu; and (3) the agency determines the facts. Winkelman v. City of Tiburon, 32 Cal. App. 3d 834, 840, 108 Cal. Rptr. 415, 419 (1st Dist. 1973) (quoting Goug v. City of Fremont, 250 Cal. App. 2d 568, 572, 58 Cal. Rptr. 664, 668 (1st Dist. 1967)). A quasi-judicial decision involves the application of existing rules to a specific set of existing facts. Patterson v. Central Coast Regional Comm'n, 58 Cal. App. 3d 833, 841, 130 Cal. Rptr. 169, 173 (1st Dist. 1976).

51. Cal. Civ. Proc. Code $\S 1094.5(b)$, (c) (West 1980). Cal. Pub. Res. Code $\S 21168$ (Wcst 1977) incorporates $\S 1094.5$ by reference, with one modification. Section 1094.5 allows the court in certain cases to exercise its independent judgmeut as to whether the findings are supported by the evidence. Section 21168 provides that in all cases the court slall apply the substantial evidence test when the decision is challenged on the grounds that it is not supported by the evidence.

52. An agency makes a quasi-legislative decision wheu it makes a decision that is not quasijudicial. See Malibu West Swimming Club v. Flournoy, 60 Cal. App. 3d 161, 164, 131 Cal. Rptr. 279, 281 (3d Dist. 1976) (setting tax rates is a quasi-legislative decisiou, not an administrative adjudication). Decisions that involve the forinulation of rules to be applied to all future cases are generally considered to be quasi-legislative. City of Coronado v. Califorina Coastal Zone Conservation Comm'n, 69 Cal. App. 3d 570, 574, 138 Cal. Rptr. 241, 243 (4th Dist. 1977). The decision of fundamentally political questions is also quasi-legislative. See Wilson v. Hidden Valley Mun. Water Dist., 256 Cal. App. 2d 271, 280-81, 63 Cal. Rptr. 889, 895-96 (2d Dist. 1967).

53. Cal. Pub. Res. Code $\$ 21168.5$ (West 1977).

54. This Comment argues that the Act does indeed limit the agency's discretion in balancing values. See notes $190-93$ and accompanying text infra. 
under the standard applicable to questions of fact, ${ }^{55}$ in this case the substantial evidence standard. Unfortunately, under the substantial evidence test courts would likely uphold the agency's choice of goals so long as it is not irrational. ${ }^{56}$ Furthermore, even if courts do review the agency's clioice of goals as a matter of law, they inay well do so in a similarly deferential manner. ${ }^{57}$

Deferential courts may be unwilling to force agencies to require major changes in projects, simce seriously modified projects are unlikely to be "successful" in attaining the agency-defined goals. Thus, a court may feel it lacks the power to overturn a project approval on the grounds that the agency should have preferred, e.g., an alternative site;

55. See L. JAFFe, Judicial Control of Administrative Action (1965): "[E]ven upon mixed questions of law and fact . . . [the administrator's] action will carry with it a strong presumption of its correctness, and the courts will not ordinarily review it. . . " Id. at 593, quoting Bates \& Guild Co. v. Payne, 194 U.S. 106 (1904). Jaffe relates this deferential approach to the standard of review for facts: "The device of characterizing a question as one of fact or as 'mixed" permits a court to pretend that it must affirm the administrative action if it is 'supported by evidence... ." L. JAFFE, supra, at 547.

Cf. K. Davis, Administrative Law Text $\$ 30.01$, at 546 (3d ed. 1972) (Supreme Court often classifies questions of administrative application as "mixed questions," treated hike questions of fact, in order to limit review).

For a CEQA case demonstrating deferential, substantial evidence treatment of the mixed question of infeasibility, see Foundation for San Francisco's Architectural Heritage v. City and County of San Francisco (City of Paris), 106 Cal. App. 3d 893, 165 Cal. Rptr. 401 (1st Dist. 1980), hg. denied, Aug. 21, 1980, and discussion of that opinion at text accompanying notes 94-102 infra.

56. "If reasonable men differ fairly as to whether certain evidence estabhishes a fact in issue, it is 'substantial evidence.'" Estate of Martim, 270 Cal. App. 2d 506, 515, 75 Cal. Rptr. 911,916 (1st Dist. 1969). "[Substantial evidence] is " "such relevant evidence as a reasonable man might accept as adequate to support a conclusion" ' . . . ." Traxler v. Thoinpson, 4 Cal. App. 3d 278, 285, 84 Cal. Rptr. 211, 216 (3d Dist. 1970) (emphasis omitted) (citing Estate of Teed, 112 Cal. App. 2d 638, 644, 247 P.2d 54, 58 (2d Dist. 1952), which in turn quoted Consolidated Edison Co. v. NLRB, 305 U.S. 197, 229 (1938)). " "[T] the term "substantial evidence" should be construed to confer finality upon an administrative decision on the facts when, upon an examination of the entire record, the evidence, including the inferences therefrom, is found to be such that a reasonable man, acting reasonably, might have reached the decision[.]' " A.F. Gilmore Co. v. County of Los Angeles, 186 Cal. App. 2d 471, 477, 9 Cal. Rptr. 67, 72 (2d Dist. 1960) (emphasis in original) (quoting Stason, "Substantial Evidence" in Administrative Law, 89 U. PA. L. REv. 1026, 1038 (194I)). Thus, the courts have viewed the substantial evidence standard as a signal of deference.

Courts reviewimg the agency's choice of goals under the substantial evidence standard may defer totally to that policy decision because the substantial evidence standard is relatively deferential and because the courts cannot literally check to see if there is substantial evidence supporting the agency's value preferences. Values are not supported or unsupported by evidence so much as they are important or unimportant, widely or narrowly shared. Professor Martin Shapiro, in his Administrative Law course at Boalt Hall in Spring 1979, suggested that the substantial evidence standard is of little use in reviewing anything other than a factual question as to what has happened or is likely to happen.

57. See notes 248-61 and accompanying text infra. Simce the substantial evidence test does not apply to questions of law, and since the question of whether an alternative is feasible is a mixed question, courts unight scrutinize the agency's choice of goals more closely by reviewing it as a matter of law. This possibility is explored in a later section of this Comment. See notes 188 . 247 and accompanying text infra. 
a plan for an innovative, nonstructural alternative to a proposed structural project; 58 the "no-project alternative",;9 or even so simple an adjustment as a plan for clustered condominiums instead of a singlefamily subdivision. This is unfortunate, because in inany cases only radical changes will be sufficient to prevent further environmental degradation. For example, areas that should be left as open space will not be preserved if all that is required is that projects proposed for such areas be environmentally well-designed. Such tracts might be protected, however, by entirely relocating projects when less sensitive sites are available. The 1976 amendments appear to require the approving agency to prefer a superior alternate location. But agencies are less likely to comply with this requirement if it cannot be enforced substantively.

A law that purports to limit the choices an agency can make, but whose limits are unenforceable, does little more than a purely procedural law. It can only encourage an agency to make the right decision, and so it is not really substantive. ${ }^{60}$ For example, a reversal for failure to consider an alternative only delays a project; the agency remains free to consider and then reject the alternative. ${ }^{61}$ Since procedural reversals explicitly criticize only the agency's explanation of its reasoning or its failure to mvestigate, they may merely encourage agencies to justify their decisions more carefully. At most they encourage agencies to rethink their decisions. For example, a local planning board with a prodevelopment bias is unlikely to make an environinentally sensitive decision, no matter how carefully it thinks through its decision, unless it suspects that its antienvironmental decisions will be overturned by the courts. The likelihood of that occurrence is conveyed to the agencies by an explicitly substantive reversal of an agency decision. No such message is conveyed by a law which is nominally substantive, but whose standard of review is so lax that no agency decisions are ever reversed under it. Similarly, so long as some agencies with CEQA responsibilities remain indifferent or even hostile to environmental values, $^{62}$ the EIR procedure, which requires agencies to consider

58. For example, energy conservation would be a nonstructural alternative to building a new power plant.

59. 14 CAL. ADMiN. CODE $\$ 15143$ (d) (May 10, 1980) (part of the State EIR Guidelines) requires that "[ $[$ ]he specific alternative of 'no project' must also always be evaluated [in the EIR], along with the impact [of not undertaking the project]." See also note 39 supra.

60. What a court could order an agency to do is what an agency really inust do.

61. The threat of delay may encourage the adoption of an alternative to the proposed project, at least where the project's proponent is unwilling to incur the costs of the delay. See notes 136-37 and accompanying text infra.

62. For an example of an agency's intransigent refusal to consider environmental values, see People v. County of Kern, 62 Cal. App. 3d 761, 133 Cal. Rptr. 389 (5th Dist. 1976), prior decision 39 Cal. App. 3d 830, 115 Cal. Rptr. 67 (5th Dist. 1974). For an example of an agency apparently 
environmental factors, will be insufficient to produce environmentally desirable decisions. The availability of substantive review in the courts, by contrast, would provide a second chance for environmentally sensitive decisionmaking. A substantive reversal would prohibit agency approval of an environmentally damaging project. Thus, a substantive reversal would provide greater protection against the environmental threat posed by the particular project, and would more likely inspire coinpliance with the pohies of CEQA when agencies consider other projects. ${ }^{63}$

\section{B. Case Law Reveals a Reluctance to Enforce CEQA Substantively}

\section{Laurel Hills}

Case law to date does not disclose a willingness on the part of the courts to enforce CEQA substantively. Laurel Hills Homeowners Association v. City Council ${ }^{64}$ was the first, and for a long time the only, publislied opinion in which the duty to prefer feasible mitigation measures and feasible, environmentally superior project alternatives was directly in issue. ${ }^{65}$ In Laurel Hills, a developer had proposed to build 124 units of simgle-family housing on a tract in the Santa Monica Mountains. The city's EIR identified aesthetic, grading, and traffic impacts as significant environmental impacts of the project. The EIR suggested inodifications of the project. It also evaluated alternative projects on

biased against environmental valnes by its mission, see Decision Accolnpanying Order Directing California-American Water Company to Construct etc. the Canada de la Segunda Pipeline and Begonia Iron Removal Plant Project in Monterey County, California Public Utilities Commission, Decision No. 87715, Case No. 9530, Nintl Interim Order, (Aug. 16, 1977) [hereinafter cited as PUC Decision: Cal-Am Water Co.], discussed at text accompanying notes 154-63 infra. See Residents Ad Hoc Stadiuin Comm. v. Board of Trustees, 89 Cal. App. 3d 274, 285, 152 Cal. Rptr. 585, 592 (3d Dist. 1979) ("CEQA assumes as inevitable an institutional bias within an agency propos* ing a project"); Note, Substantive Review Under the National Environmental Policy Act: EDF v. Corps of Engineers, 3 ECOLOGY L.Q. 173, $197-98$ (1973) (agencies often biased by their inission and by political expediency).

63. Cf. Bryden, Environmental Rights in Theory and Practice, 62 MiNN. L. Rev. 163, 219 (1978) (even substantive enforcement lias little deterrent effect due to uncertainty as to whether a court will enjoin a project if someone sues). Furthernore, there is always the possibility that the legislature will overturn the court's decision. See notcs 364-67 and accoinpanying text infra.

64. 83 Cal. App. 3d 515, 147 Cal. Rptr. 842 (2d Dist. 1978).

65. The court in Laurel Hills found that CAL. PuB. Res. Code $\$ \S 21002,21002.1$ (West 1977) were declarative of the pre-existing law. 83 Cal. App. $3 d$ at 519-20, 147 Cal. Rptr. at 845. The court cited both Friends of Mammoth v. Board of Supervisors, 8 Cal. 3d 247, 263 n.8, 502 P.2d 1049, 1059 n.8, 104 Cal. Rptr. 761, 771 n.8 (1972) and County of Inyo v. City of Los Angeles, 71 Cal. App. 3d 185, 203, 139 Cal. Rptr. 396, 408 (3d Dist. 1977), in support of its opinion that CEQA limited the power of agencies to approve environmentally damaging projects even prior to passage of the 1976 amendments. In both of the cited cases, however, the courts reversed the agencies' actions on procedural grounds. 
the same site, ${ }^{66}$ including a sixty-three-unit clustered condominium project that it identified as environmentally superior. The city approved a modified project of ninety-five single-family homes that imcorporated most of the suggested mitigation measures. In approving the project, the city adopted a statement of overriding considerations ${ }^{67}$ that explamed why it approved the nodified project despite soine remaining adverse environmental impacts. The city made no finding that the environmentally superior condominium project $^{68}$ was infeasible, and the Homeowners Association sued to overturn the approval.

The court held that the city did not have to consider the feasibility of the environmentally superior clustered condominium "alternative" because the imposition of "mitigation measures," the change to a smaller, single-family project, reduced the significant adverse environmental impacts to an "acceptable level." 69 This conclusion has been criticized as setting up an undefined and lax standard, an "acceptable level" of environmental degradation, for determining how far an environmental impact must be reduced before an agency must make findings of infeasibility. ${ }^{70}$ Findings requirements generally implement substantive requirements. Thus, the Laurel Hills opmion also absolved the agency from further responsibility to impose feasible ineans of lessening environmental impacts once they are reduced to an "acceptable level. ${ }^{.71}$

The reasonimg of the Laurel Hills opinion is flawed. The court felt that imposing "mitigation measures" without considering "project al-

66. See Los angeles City Planning Department, Proposed Final EIR, Summary at XV, (Los Angeles City Planning Department EIR No. 415-75-SUB) (Apr. 13, 1976).

67. The State EIR Guidelines require a written "Statement of Overriding Considerations" explaining the reasons for an agency's approval of a project where the "agency allows the occurrence of significant effects which are identified in the final EIR but are not mitigated." $14 \mathrm{CAL}$. ADMIN. CODE $\S 15089$ (b) (May 10, 1980). For more complete text, see note 139 infra. Such a stateinent may also be necessary if the agency finds proposed alternatives or mitigation measures to be infeasible. CAL. AdmIN. CoDE $\S 15089$ (b) (May 10, 1980). The above requirement apparently reflects the holding in Burger v. County of Mendocino, $45 \mathrm{Cal}$. Ap. 3d 322, $119 \mathrm{Cal}$. Rptr. 568 (1st Dist. 1970). "Where agencies have taken action resulting in environmental damage without explaining the reasons which supported the decision, courts have invalidated the action." 14 CAl. Admin. Code $\S 15089$ (a) (May 10, I980).

68. The condominium project would have further reduced the amount of grading considerably, both by reducing the number of umits and by clustering them on a smaller portion of the site. See Petitioners' Reply Memorandum of Points and Authorities 43 (on file with Antonio Rossman, Esq.).

69. 83 Cal. App. 3d at 521, 147 Cal. Rptr. at 846.

70. This criticism was made by Note, CEQA's Substantive Mandate Ciouded, supra note 15, at $10210-11$.

The statutory findings requirement of CAL. PUB. REs. CoDE $\$ 21081$ (West 1977) was not before the Laurel Hills court. See Hill, supra note 35, at 6.

71. Cf. text accompanying notes 86-93 infra (new EIR Guidelines indicate that substantive duty exists whether or not written findings are required). 
ternatives" was sufficient because section 21002 speaks of them in the alternative: e.g., "[if] conditions make infeasible such project alternatives or such mitigation measures, individual projects may be approved in spite of one or more significant effccts thereof." 72 However, there is no clear distinction possible between project alternatives and mitigation measures. Was the ninety-five-unit project approved in Laurel Hills an alternative project or the original project with mitigation measures? Proposed changes range along a continuum from the very minor, e.g., landscaping with desert plants to conserve water, to the very major, such as relocating the entire project. $^{73}$

The court's reading of section 21002 does not rest on any real distinction between mitigation measures and project alternatives. Rather, it rests on the court's behef that CEQA does not require agencies to choose the "environinentally best feasible project,"74 but only requires that adverse effects be reduced to an "acceptable level."75 However, even before the 1976 amendments to CEQA added substantive emphasis to the Act, the California Supreme Court, in Friends of Mammoth, required CEQA to be interpreted "in such a manner as to afford the fullest possible protection to the environment within the reasonable scope of the statutory language."76 The Laurel Hills court certainly did not construe the statute in that manner. ${ }^{77}$

Furthermore, section 21002 states that agencies should not approve projects as proposed if "feasible alternatives or feasible mitigation measures [are] available which would substantially lessen the significant environinental effects."78 Thus, if either superior alternatives or mitigation measures are feasible, the proposed project should be disapproved. The policy of substantially lessening signficant impacts should apply to the project the agency presently proposes to approve, as well as to the project originally proposed. Thus, if the agency is proposing to impose "mitigation measures," but a feasible "project alternative" would have substantially less impact than the project with "mitigation measures," then the statute prohibits the agency from merely imposing the "mitigation measures."

72. CAL. PuB. Res. CODE $\$ 21002$ (West 1977) (emphasis added), quoted at note 32 supra; see 83 Cal. App. 3d at 521, 147 Cal. Rptr. at 846.

73. See note 20 supra.

74. 83 Cal. App. 3d at 521, 147 Cal. Rptr. at 846.

75. Id.

76. Friends of Mammoth v. Board of Supervisors, 8 Cal. 3d 247, 259, 502 P.2d 1049, 1056, 104 Cal. Rptr. 761, 768 (1972), quoted in Laurel Hills, 83 Cal. App. 3d at 520, 147 Cal. Rptr. at 845. The Laurel Hills court, quoting Friends of Mammoth, emphasized only the requirement of interpretation "within the reasonable scope of the statutory language." Id..

77. See Note, CEQA's Substantive Mandate Clouded, supra note 15, at 10210-11.

78. CAL. Pub. Res. CODE $§ 21002$ (West 1977) (emphasis added).

79. Thus, where the approved mitigation measures reduce an adverse impact, but do not 
agency is not required to impose an insubstantially superior "alternative."

Section 21002 does not imply, as the Laurel Hills opimon incorrectly suggests, that the originally proposed project's adverse effects need only be substantially reduced in order to be "acceptable." tion 21002.1 does say that each agency shall "mitigate or avoid" significant adverse environmental impacts. ${ }^{81}$ While this could be interpreted to mean that impacts can either be mitigated or entirely avoided at the discretion of the agency, an interpretation more in keeping with $\mathrm{Mam}$ moth would be that mitigation is an alternative to avoidance of an impact only where avoidance is infeasible. ${ }^{82}$

In any case, the result reached in Laurel Hills may not depend on the appellate court's interpretation of CEQA. The trial court found substantial evidence to uphold "the city's determination that the subdivision after imposition of mitigation measures . . . would not have sigmificant adverse environmental effects." 83 The appellate court neither expressly approved nor disaffirmed this finding. ${ }^{84}$ If the trial court's finding was correct, the city was under no duty to impleinent any other changes, because impacts that have been reduced to the level of "insignificance" need neither be mitigated nor avoided. ${ }^{85}$ In that case, the

reduce it to the level of insignificance, the agency must find superior alternatives infeasible if it fails to adopt them. In that situation, the agency must make an explicit finding of the alternative's infeasibility. Cal. Pub. Res. Code $\$ 21081$ (quoted at note 34 supra) and 14 CaL. Admin. Code $\$ 15088$ (May 10,1980) (quoted at note 143 infra) require the agency to make "one or more" of the prescribed findings (emphasis added). The prescribed findings imclude both a finding that effects lave been mitigated and a finding that further reduction of the environmental impact is infeasible.

While alternatives and mitigation measures clearly are situated on the same continuum, a very minor change in a project can be called a mitigation measure witlout any risk of confusion. Calling such a major change as building the project somewhere else a mitigation measure, however, would be misleading. It could only be called an alternative.

80. Cf. Laurel Hills Homeowners Ass'n v. City Council, 83 Cal. App. 3d 515, 521, 147 Cal. Rptr. 842, 845 (2d Dist. 1978) (if mitigation measures substantially lessen the adverse effects, project alternatives need not be considered). Note, CEQA's Substantive Mandate Clouded, supra note 15, at 10210-11, argues that Laurel Hills might encourage project proponents to propose projects with horrendous environmental impacts in order to gain approval of "modified" projects, with substantially less impact, for which they had really wanted approval in the first place.

81. Cal. Pub. Res. Code $\$ 21002.1$ (b) (West Supp. 1979) (emphasis added).

82. Foundation for San Francisco's Architectural Heritage v. City and Colmty of San Francisco (City of Paris), 106 Cal. App. 3d 893, 912-13, 165 Cal. Rptr. 401, 412 (1st Dist. 1980), hg. denied, Aug. 21, 1980, also discussed the "mitigate or avoid" language. The court noted that the local agency had both substantially mitigated the adverse impacts and determined that further mitigation was infeasible. The revised Guidelines discussed at text accompanying notes 86-93 infra also indicate that the agency must both reduce significant impacts where feasible and determine that further reduction is infeasible.

83. 83 Cal. App. 3d at 525, 147 Cal. Rptr. at 848 .

84. Id.

85. Cal. Pub. Res. Code $\$ \S 21002,21002.1$, and 21081 (West 1977 \& Supp. 1980) all refer to the duty to mitigate "significant" effects. See notes 32,34 supra for text of these sections. See 
appellate court's reference to some different, undefined level of "acceptability" was unnecessary dicta. If that is so, agencies must still find alternatives and further mitigation measures infeasible, unless the mitigation measures imposed have reduced impacts to the level of insignificance.

Because there is no sharp line between alternatives and mitigation measures, and to simplify discussion, this Comment from now on will include projects as modified by mitigation measures within the term "alternatives." Thus whenever this Comment refers to the duty to disapprove a project because there is an environmentally superior alternative, it is also referring to the duty to disapprove a project because there are feasible mitigation measures.

Recent revisions in the EIR Guidelines ${ }^{86}$ attempt to deal with the Laurel Hills terminology. ${ }^{87}$ Section 15088(d) of the Guidelmes now states that "[a] public agency shall not approve or carry out a project as proposed unless significant environmental effects have been reduced to an acceptable level" (emphasis added). Subsection (e) then states that effects are reduced to an acceptable level where (1) "effects that can feasibly be avoided have been eliminated or substantially lessened" and (2) "[a]ny reinaining unavoidable effects have been found acceptable under section 15089 [of the Guidelines]." Section 15089 "requires the decision maker to balance the benefits of a proposed project against its unavoidable environmental risks in determining whether to approve the project." Thus, under the revised Guidelines an adverse effect is not reduced to an "acceptable level" just because it is substantially lessened. The remaining unavoidable effects must also be outweighed by countervailing benefits. Thus, effects are only acceptable if it is infeasible to reduce them further. This is an accurate restatement of the law. ${ }^{88}$

The revised Guidelines are less clear as to whether this balancing process must be explained in all cases by means of written findings. Written findings must be made where adverse effects "are identified in the final EIR but are not mitigated . . .."89 And written findings "may be necessary if the agency also makes a finding ... [of in-

Laurel Hills Homeowners Ass'n v. City Council, No. C 193823, at 11 (Super. Ct. Los Angeles County, Findings of Fact and Conclusions of Law, Nov. 3, 1977), affd on other grounds, 83 Cal. App. 3d 515, 147 Cal. Rptr. 842 (2d Dist. 1978); Hill, supra note 35, at 5.

86. See note 39 supra for a discussion of the Guidelines' authority.

87. 14 CAL. AdmIN. CODE \& 15088(d), (e) (first published May 10, 1980). Section 15088(a)(c) is quoted at note 143 infra.

88. The revised Guidelines are briefly discussed in Jolinson, "An Open Letter to People Concerned with Environmental Impact Reports," Cal. EIR Monitor (Apr. 8, 1980) and in Memoranduin re Amendments to A.B. 2679 froun Norman Hill, Office of Public Resources, to Claire Dedrick (Apr. 29, 1976) (on file with the California Law Review).

89. 14 CAL. ADMin. CODE $\$ 15089$ (b) (May 10, 1980). 
feasibility]."90 The revised Guidelines stress the desirability of making written findings, ${ }^{91}$ without expressly contradicting Laurel Hills' conclusion that written findings are not necessary when mitigation measures substantially lessen adverse effects. ${ }^{92}$ However, the revised Guidelines make it clear that even if written findings are not required, the agency still cannot approve a project with significant adverse effects remaining unless it is infeasible to further lessen those effects. ${ }^{93}$

\section{City of Paris}

A recently publislied opinion, Foundation for San Francisco's Architectural Heritage v. City and County of San Francisco (City of Paris),${ }^{94}$ also turned on the duty to prefer feasible superior alternatives. The plaintiffs challenged San Francisco's approval of a plan to demolisli tlie City of Paris department store building, a building of historical and architectural interest. The plaimtiffs contended that the city's action violated the substantive provisions of CEQA.95 In particular, they challenged the city's finding that there was no feasible and prudent alternative to the developer's plan, which was to demohsh the old structure and retain only the significant interior architectural features. Since the city had found that alternatives were infeasible, the plaintiffs were not questioning a failure to inake findings as were the plaintiffs in Laurel Hills, and that case is not mentioned in the City of Paris opimion. ${ }^{96}$

The City of Paris court reviewed the city's findings of infeasibility under the substantial evidence test. ${ }^{97}$ Its opinion did not consider other possible means of substantively reviewing a local agency's findings, i.e., review as a matter of law. ${ }^{98}$ The court held that there was substantial evidence to support the agency's factual determination of the disadvantages of alternatives that would have preserved the building intact. The

90. Id.

91. See 14 CAL. Admin. Code § 15089(a) (May 10, 1980).

92. But see note 79 supra for the author's argument that CAL. PUB. REs. CODE $\S 21081$ (West 1977) requires a written finding that alternatives are infeasible even where adopted mitigation measures have substantially lessened the project's environmental impact. Hill, supra note 35 , at 6 , points out that $\$ 21081$ was not before the Laurel Hills court.

93. See text accompanying note 71 supra.

94. 106 Cal. App. 3d 893, 165 Cal. Rptr. 401 (1st Dist. 1980), hg. denied, Aug. 21, 1980.

95. Id. at $910,165 \mathrm{Cal}$. Rptr. at 411 . The plaintiffs also advanced several procedural claims, which were rejected by the court. Id. at 906-10, 165 Cal. Rptr. at 408-11.

96. However, the court did suggest, as the Laurel Hills opinion had, that major mitigation of impacts satisfied the agency's duty to "mitigate or avoid" significant effects. Id. at 912, $165 \mathrm{Cal}$. Rptr. at 412. But the court also noted that the City of San Francisco had found further mitigation to be infeasible. See note 82 and text accompanying notes $86-88$ supra (dual requirement to mitigate effects where feasible and determine that further mitigation is infeasible).

97. 106 Cal. App. 3d at $905 \&$ n.5, 913, 165 Cal. Rptr. at $406 \&$ n.5, 412.

98. See text accompanying notes 50-55 supra and 188-261 infra discussing review of agency findings of infeasibility as a "matter of law." 
opinion concluded its substantive review by asserting that courts cannot reevaluate an agency's "conclusion that the adverse economic consequences of the preservation alternatives ... outweighed the other factors [favoring preservation] . . .."99 The court did not cite any authority to support this assertion. It did note that the statute "does not require the Board to reach a conclusion in favor of environmental values in each instance." 100 Since the Act permits a balancing of environmental factors against economic and other factors, it is certainly true that the agency is not required to prefer environmental values in every case. But that does not imply that the agency is never required to prefer environmental values. ${ }^{101}$ Yet the court refused to review the balance struck by the agency; it declined to review the agency's "choice of goals." The City of Paris case thus illustrates the danger that courts employing the substantial evidence test will fail to review the agency's exercise of discretion in choosing goals, even though the Act limits the agency's discretion. ${ }^{102}$

Still, City of Paris does not preclude review of the agency's findings of infeasibility as a matter of law or by the use of procedural techniques. And even under the most crabbed interpretation of Laurel Hills there will remain occasions when agencies will need to consider the feasibility of alternatives. ${ }^{103}$ Thus, agency determinations that alternatives are infeasible remain subject to court review. The critical question is whether agencies will too easily be able to estabhish that

99. 106 Cal. App. 3d at 913, 165 Cal. Rptr. at 412.

100. Id.

The plaintiffs claimed that the agency had disregarded "the substantive mandate of CEQA to give greater weight to environmental values than the needs of economic growth. . . " Id, citing San Francisco Ecology Center v. City and County of San Francisco, 48 Cal. App. 3d 584, 591, 122 Cal. Rptr. 100, 104 (1st Dist. 1975). See notes 25-27 and accompanying text supra discussing the courts' refusal to substantively enforce the pre-1976 policy sections of CEQA.

101. This Comment argues that CEQA does limit the agency's discretion to balance values. See, e.g., text accompanying notes 190-95 infra.

102. The author of this Comment is not here arguing that the agency's decision to approve the project should have been overturned as a matter of law. But see note 203 and accompanying text infra, suggesting that at least some of the agency's factual findings provided a legally imadequate basis for its determination that alternatives were infeasible. The decision may have been within the range of allowable discretion. What is disturbing about the opinion is its total failure to review the balance struck by the agency, its failure even to articulate a standard for reviewing that balance, and its failure to note that the law does limit the agency's discretion in balancing values.

103. Laurel Hills appears to restrict the requirement of finding "alternatives" imfeasible to cases where mitigation measures have not reduced impacts to an "acceptable" level. Even under that interpretation of the statute, agencies would be required to make findings if they decided to approve projects as proposed without modifications, or if the modifications imposed still did not reduce impacts to an "acceptable" level. Furthermore, Laurel Hills may be read as still requiring agencies to consider the feasibility of further modification so long as impacts are not reduced to an "msignificant" level. This seems to the author to be the correct interpretation of the law. See text accompanying notes 83-88 supra. 
environmentally superior alternatives are infeasible, so that CEQA's substantive requirements become practically unenforceable.

\section{Agencies May Be Able to Shield Project Approvals from Reversal if the Courts Fail to Scrutinize Findings of Infeasibility}

CEQA mandates the rejection of projects only when there are feasible environmentally superior alternatives. It may be difficult for the courts to enforce this statutory mandate, because an alternative that fails to achieve the goals selected by the agency might be said to be infeasible. This may present difficnlties even when an agency enunciates its goals after a good faith effort to balance interests. If an agency were to manipulate project goals, in bad faith, it might more easily circumvent environmental concerns. Thus, if the courts fail to scrutinize findings of infeasibility, agencies may too easily shield project approvals from reversal by demonstrating that suggested alternatives fail to fulfill the goals articulated by the agency. ${ }^{104}$

There are a number of ways in which an agency might make alternatives seen infeasible by its choice of goals. By insisting that an alternative must provide the same quantity of whatever it is that the project is supposed to produce (e.g., housing units, acre-feet of water), an agency might claim that all alternatives that fail numerically to meet the chosen goals of the origimal project are infeasible. Or alternatives might appear infeasible because of the kind of goals the agency has chosen, e.g., highly particularized, overly localized goals that rule out alternate locations or methods. Similarly, an agency might pursue inherently antienvironmental goals, which would make less harmful alternatives seem unsuccessful. In any case, if the agency can select the goals that an alternative must meet to be considered feasible, then it could approve a project that will cause harm outweighing the benefits derived froin the project. Thus, the basic problem with the existing law is that if courts must accept the agency's "choice of goals," they may be unable to require the degree of environmental protection contemplated by the statute.

104. By declaring that the purpose of a residential subdivision is to provide detached, singlefamily housing, an agency could unake clustered housing alternatives seem infeasible. Those alternatives, however, might cause less environmental harm on a steep site. (This hypothetical is based on the facts of Laurel Hills Homeowners Ass'n v. City Council, $83 \mathrm{Cal}$. App. 3d 515, $147 \mathrm{Cal}$. Rptr. 842 (2d Dist. 1978).) The local agency could define the project's goal this way merely because it wants to let the developor proceed with the project he has proposed. The local government may otherwise be indifferent to whether the additional housing it believes the community needs is provided in detached or clustered dwellings. Or the local governmeut may in fact want only single-family housing because, for example, the neighbors are strongly opposed to clustered lousing on the site (as appears to lave been the case in Laurel Hills). See Laurel Hills Homeowners Ass'n v. City Council, No. C 193823, at 3, 51, 11 (Super. Ct. Los Angeles County, Findings of Fact and Conclusions of Law, Nov. 3, 1977). 
Many of the ways in. which an agency might make alternatives seein infeasible are illustrated by the statement of overriding considerations adopted by the City of Los Angeles and reported in Laurel Hills Homeowners Association v. City Council. ${ }^{105}$ Throughout the rest of this Comment, Laurel Hills will be used only as a hypothetical fact situation for investigating how courts might review the substance of agency findings of infeasibility. ${ }^{106}$

The facts of Laurel Hills illustrate how an alternative may fail quantitatively to meet each of the approved project's goals. Some of the benefits the city expected to realize from the approved project were: construction einployment in excess of fourteen million dollars, increased local consuiner purchasing power of nearly three million dollars per year, and ninety-five units of housing. ${ }^{107}$ The plaintiffs in Laurel Hills were unable to persuade the court to consider the feasibility of the sixty-three-unit clustered condominium project alternative identified in the EIR as "environmentally superior." 108 However, if the court had considered the smaller project, and if it felt it had to accept the agency's choice of goals, it probably would have found the smaller project "unsuccessful." The smaller project would have provided significantly less housing and, inost likely, significantly less consumer purchasing power and construction einployinent as well. ${ }^{109}$

The nature of the goals chosen by the agency may also make alternatives seein infeasible. In the Laurel Hills findings the city attempted to justify its decision to approve the project by poimting to several highly particularized goals. The city sought to retain the single-family "residential character of the surrounding area," 110 and so decided that a certain type of housing and no other would ineet the community's needs. The city sought nore public revenue than would be absorbed by the project; it also wanted to have the intersection of Mulliolland and Coldwater Canyon Drives reconstructed. ${ }^{11}$ Local governments tend to approve projects which provide benefits within their own juris-

105. 83 Cal. App. 3d 515, 523-25, 147 Cal. Rptr. 842, 847-48 (2d Dist. 1978).

106. In effect, this Comment now turns to consider what would have happened if the Laurel Hills court had construed the law correctly. As noted above, however, agencies may still want to prove alternatives infeasible even under the Laurel Hills imterpretation of the law. See notc 103 and accompanying text supra.

107. 83 Cal. App. 3d at 523-24, 147 Cal. Rptr. at 847.

108. Id. at 520-22, 147 Cal. Rptr. at 845-46.

109. The trial court, in its Findings of Fact and Conclusions of Law, held that the clustered condominium alternative was infeasible. Apparently, one rcason for its holding was the loss of social, economic, and environmental benefits that were to be provided by the approved project. Laurel Hills Homeowners Ass'n v. City Council, No. C 193823, at 11-12 (Super. Ct. Los Angeles County, Nov. 3, 1977), aff'd on other grounds, 83 Cal. App. 3d 515, 147 Cal. Rptr. 842 (2d Dist. 1978).

110. $83 \mathrm{Cal}$. App. 3d at 524, $147 \mathrm{Cal}$ Rptr. at 847.

111. Id. 
dictions, even though the projects might better be located elsewhere within the region. Local government agencies may weigh these local benefits of a project more heavily than the environmental harm caused by the project when much of the detriment is felt by those outside of their jurisdiction. ${ }^{12}$ For example, a locahity anxious to become an upper-middle-class "bedroom" commumity may approve extensive residential subdivision even though other communities located closer to employment opportunities have housing sites available. Similarly, a community that wants to mcrease its property tax revenues might rezone an ecologically important area of marshland to allow the development of a regional shopping center, even though less environmentally damaging sites for such a shopping center are available in nearby communities.

Agency goals may not only be overly particularized, they may be antienvironmental. ${ }^{113}$ Public agencies may stimulate undesirable growth, for example, by approving public works projects such as a greatly expanded water supply for a commumity that has reached the limits of its present supply. ${ }^{114}$ Local governments anxious to "maintain the character" of their commumities may approve sprawling suburban subdivisions which destroy open space and aggravate air pollution problems by requiring long automobile trips to get anywhere. ${ }^{115}$

Thus, problems may arise where the agency insists on achieving much more than the basic purpose of the project. If the agency is free to choose goals that are overly particularized or even antienvironmental, then it may seek to characterize superior alternatives as infeasible. If the courts defer to the agency characterization, the agency may be able to shield its decision to approve the project from substantive review even where the environmental harm outweighs the benefits realized from the project.

Private development projects, the focus of this Comment, ${ }^{116}$ may fulfill private goals in addition to public goals such as those discussed above. This Comment distimguishes two types of claimed infeasibility. Claims of public infeasibility are claims that an alternative fails to meet

112. Comment, supra note 27, at 105, 111-12, stresses the relative unimportance of local goals as compared with regional goals in considering the environmental and economic costs and benefits of a project.

113. Other goals may not be inherently antienvironmental, but given particular circumstances will yield excessive environmental harm. Agencies that are indifferent or hostile to environmental values may pursue these goals as well. See note 62 supra.

114. See PUC Decision: Cal-Am Water Co., supra note 62.

115. See discussion of Laurel Hills at text accompanying notes 110-11 supra, discussion of Hayward's rezoning of the Soda property at text accompanying note 151 and at notes 152-53 infra: discussion of the Livermore Residential Development EIR at text accompanying notes 145-49 infra.

116. See note 6 and accompanying text supra. 
certain public goals. Claims of private infeasibility-claims that an alternative fails to meet private goals, such as producing a profit for the developer. ${ }^{117}$ Standards for judging claims of infeasibility will be discussed below. ${ }^{118}$ The standards for judging claims of public and private infeasibility may need to differ. On the other liand, it may be that claims of private infeasibility, like those of public infeasibility, ought to be rejected whenever the liarm avoided by imposing the alternative is clearly more important than the unmet goal. ${ }^{119}$

Alternatives that achieve the public goals of a project may not ineet the private goals, and vice versa. If an agency fails to identify alternatives that might meet both the public and private goals, then it may only consider alternatives that seem infeasible. ${ }^{120}$ Thus, an agency may seek to justify its approval of a private project on the basis of the public benefits the project would provide, without considering alternative ways of providing those benefits. For example, in Laurel Hills, the only alternatives considered by the agency were onsite alternatives. ${ }^{121}$ Since the environmentally superior onsite alternative would have provided less lousing, less construction employment, and less of an increase in local purcliasing power than the approved project, that alternative would liave been unsuccessful in yielding the public benefits the approved project was to provide. Thus, by failing to consider the availability of offsite locations for those housing umits not provided by the environmentally superior onsite alternative, the local agency could liave made that alternative seem infeasible. ${ }^{122}$

The facts of Laurel Hills suggest another way in which environinentally superior alternatives might be made to appear infeasible: an agency could set up suclı a multitude of goals for a project that it would

117. An alternative may be infeasible not only because it does not meet certain goals but because it is mcapable of being carried out. See text accoinpanying notes 200-02 infra.

118. See text accompanying notes 196-231 infra.

119. See text accompanying notes $232-41$ infra.

120. Similarly, it may be necessary to identify alternatives capable of ineeting several different public goals.

121. See Los Angeles City Planning Department, Proposed Final EiR, Summary at XV (Los Angeles City Planning Department EIR No. 415-75-SUB) (Apr. 13, 1976).

It was proper to consider onsite alternatives, because from the developer's point of view an entirely offsite alternative would have been totally unsuccessful ("infeasible"), because it would not have provided for any profitable development of his land.

122. In other words, the agency should have considered a combimation project: construction of a smaller-scale project onsite, and additional housing offsite.

If a court were to accept such a claim of public infeasibility, the developer would not have to slow that the rejected alternative was unprofitable in order to prove mfeasibility. The developer in Laurel Hills claimed that the sixty-three-umt, clustered condominium alternative would be unprofitable (and therefore "infeasible"). The plaintiffs argued that its unprofitability had not been shown. The plaintiffs apparently hoped that the developer would have to prove the alternative's unprofitability in order to prove its infeasibility. See Petitioners' Reply Memoranduin of Points and Authorities 40-43 (on file with Antonio Rossman, Esq.). 
be difficult to conceive of any combination of alternatives that could provide that precise combination of benefits. ${ }^{123}$ Thus, a major difficulty in enforcing CEQA substantively is preventing agencies from sheltering their project approvals from court review by a careful definition of project goals. Agencies might attempt to shelter their decisions by forinulating quantitatively or qualitatively restrictive goals, by articulating a great many goals, or by failing to identify alternatives that could satisfy all of the chosen goals. Courts will need some way to review the agency's choice of goals and determinations of infeasibility if they are to enforce CEQA's substantive mandate.

\section{III \\ Rigorous Enforcement Might Be Possible UndeR EXISTING LAW}

This section of the Comment discusses how, under existing law, the courts might enforce CEQA's policy that environmentally damaging projects be disapproved when environmentally superior alternatives are feasible. Two procedural techniques of encouraging coinpliance with this policy are considered: remanding for consideration of additional alternatives, and remanding for a more adequate explanation. Procedural review of agency findings of infeasibility remains possible under CEQA, even if the substantial evidence test tends to shield the agency's choice of goals for a project from substantive review. Quasi-substantive application of these procedural techniques is also discussed. Finally, several techniques of explicitly substantive review are considered. Substantive review under the substantial evidence test is not discussed at length because, as suggested above, ${ }^{124}$ little real substantive review seeins likely under that deferential test. Instead, this Comment examines several "matter of law" techniques. ${ }^{125}$ Some of these would have the courts construe CEQA as imposing substantive requirements more detailed than those exphicitly set out in the Act. In particular, they would allow courts to impose additional costs on projects in order to reduce environmental harm. Otlier techniques would allow the courts to look inore carefully at the kind of goals chosen by the agency and would allow courts to review, as a matter of law, the agency's decision that the chosen goals are im-

123. See text accoinpanying notes 107, 110-11 supra (discussing the agency's goals in Laurel Hills).

124. See notes 49-56, 97-102 and accompanying text supra.

125. This Comment refers to them as matter of law techniques because they rely on the courts' power to say what the law is by construing statutory requirements. The substantial evidence test applies to questions of fact, but not to questions of law. 
portant enough to justify imposing the predicted amount of environmental harm.

\section{A. Procedural Review}

A procedural remand inay serve purely procedural purposes. That is, a court may order compliance with procedural requirements solely for the purpose of ensuring that the agency has adequately considered the relevant factors or that it has exposed its decisionmaking to public scrutiny, e.g., by publishing findings. ${ }^{126}$ Alternatively, a court may order an ostensibly procedural remand for substantive reasons; not merely because the agency has failed to consider the issues or explam what it has done, but because the agency has made a decision that the court considers wrong. Such a remand is ordered in the hope that the agency will change its mind on reconsidering the issue, perhaps with the help of some hints in the court's opimion. This Comment refers to ostensibly procedural review that is actually motivated by substantive concerns as quasi-substantive review. Two types of procedural remands are considered next, followed by a discussion of their possible quasi-substantive use.

\section{Remand for Consideration of Additional Alternatives}

If a public agency attempts to justify its approval of an environmentally dainaging project by the need to provide public benefits without having considered alternative means of providimg those benefits, a court may reject the EIR as inadequate. ${ }^{127}$ The agency would then have to prepare an EIR that adequately. considered such alternatives before it could approve the project. Section 15143(d) of the State EIR Guidelines requires that the EIR "[d]escribe all reasonable alternatives to the project, or to the location of the project, which could feasibly attain the basic objectives of the project. . .."128 If the failure to provide a public benefit is important enough to nake an alternative to the proposed project "infeasible," then providing that benefit ought to be a basic enough objective of the project so that the EIR should have to consider alternative means of providing that benefit.

For example, in Laurel Hills the city might have used the fact that

126. See notes $21-22,37$ and accompanying text supra (discussion of study and disclosure requirements of CEQA).

127. Existing case law indicates that a court may reject an EIR as inadequate if it fails to comply with CEQA's requirement that agencies study ineaningful alternatives. See, e.g., County of Inyo v. City of Los Angeles, 71 Cal. App. 3d 185, 189, 203, 139 Cal. Rptr. 396, 399, 408 (3d Dist. 1977).

128. 14 CAL. Admin. Code $\$ 15143$ (d) (May 10, 1980) (einphasis added).

The State EIR Guidelines are part of the CAL. ADMIN. CODE. For a discussion of their authority, see note 39 supra. 
the clustered condominium alternative would have provided less housing than the approved project to attempt to show that the alternative was "infeasible." If the city had made that claim, it could have been required to consider environmentally superior, offsite alternatives as a means of providing that additional housing. ${ }^{129}$ In Laurel Hills the goals of the original project could have been met by a combination of a reduced project on the proposed site and the development of additional housing on other sites. Perhaps, the additional housing could have been provided in the future by other developers. The city did not have to consider moving the entire project to a different site. In other cases, where it is argued that any developinent on the site is inappropriate, the agency would have to consider entirely offsite alternatives. ${ }^{130}$

It might be feared that requiring consideration of offsite alternatives would routinely frustrate private developinents or increase their cost by delaymg projects in order to conduct extensive studies. ${ }^{131}$ But there are several reasons why this will not occur. In the first place, courts are unlikely to reverse agency approvals of development proposals routinely on the grounds that the agency should have studied some other location where development could take place with somewhat less environmental impact. Section 21002 does not require the agency to seek out and approve only the one best site for a project. An alternative site must be preferred only if it is substantially better from an environmental standpoint. ${ }^{132}$ Furthermore, where the impact of a

129. Cf. Comment, supra note 27, at 101 (unclear whether CEQA requires consideration of offsite alternatives to private projects). The Comment, however, argued that such alternatives ought to be considered. Id. at 104, 113.

130. In considering the feasibility of these alternative sites, a relevant factor may be the likehhood of their actually be used for housing if the requested rezoning were denied. See Note, The Least Adverse Allernative, supra note 6, at $755-56$ (noting that the practicability of an alternative dcpends on the hikelihood of its being undertaken). CAL. PUB. Res. CODE $\$ 21061.1$ (West 1977) (defining "fcasible") notes the importance of alternatives beging accoinplished "within a reasonable period of time." However, the full definition indicates that a feasible alternative is one that is "capable of being accoinphished . . . within a reasonable period of time" (emphasis added). It may be possible to use other sites, even though no developer is interested in developing any of thein.

Developers might claim that the likelihood of their trying to develop alternative sites will decrease if they are unable to develop the sites they want. They imight claim that the denial of developinent permission will convince them that there is a bad climate for development in the community, which is going to make any developinent too costly and subject to delay.

If the agency or the courts reject development proposals because inore suitable sites are available, the cost of acquiring developable land will increase as the number of developable sites decreases. If a small number of suitable alternative sites are identified when the proposal is rejected, the impact on their price might be considerable.

131. Cf. Bill Analysis of A.B. 2679, supra note 15, at 3 (CEQA attacked for requiring only production of paper and not real environinental protection). For a discussion of objections that the requirement to prefer offsite alternatives would be unfair to landowners, see notes 212-16 and accompanying text infra.

132. See CAl. Pub. Res. Code $\S 21002$ (West 1977), quoted at note 32 supra. This construc- 
particular development is not site-specific but would occur regardless of where the project is built, the EIR need not consider alternative sites in any detail. A simple statement in the EIR that these effects are an unavoidable impact of deciding to proceed with such a project should be sufficient. ${ }^{133}$ Fimally, not every goal requires the study of offsite alternatives. The requirement to study offsite alternatives is triggered by the inability of onsite alternatives or the no-project alternative to meet particular goals. ${ }^{134}$ For all these reasons, the requirement to study offsite alternatives to private development projects should be reasonably limited. ${ }^{135}$

tion of $\$ 21002$ is explained in greater detail at text accompanying notes 77-79 supra. See also CAL. PuB. Res. CoDE $\S 21081$ (West 1977) quoted at note 34 supra (state policy is to prefer alternatives which would mitigate the environmental effects of projects).

While the requireinent to study alternatives is broader than the requirement to select them, as a practical matter courts are unlikely to order the study of additional alternatives unless a plaintiff is able to suggest the existence of a sufficiently superior alternative. Cf. Sierra Club v. City of Hayward, 107 Cal. App. 3d 127, 134-35 (1st Dist. 1980), hg. granted, Aug. 21, 1980 (court ignored conclusionary testimony that alternative sites available somewhere). However, where superior alternatives are readily apparent, the agency should initiate study of them on its own.

If the use proposed for the site does not generate controversy, an agency unay be justified in failing to consider offsite alternatives. However, if the draft EIR or the public comments received in response to it suggest the existence of alternative sites with significantly less environmental impact than the proposed site, then the final EIR ought to investigate that possibility. See note 142 infra explaining the preparation of draft and final EIRs. $14 \mathrm{C}_{\mathrm{AL}}$. ADMIN. CoDE $\$ 15146$ (May 10,1980 ), quoted in part at note 141 infra, requires the agency to respond in detail to significant environmental comments and suggestions when the agency does not accept those comments or suggestions. Considering alternatives during preparation of the EIR, rather than after litigation and a judicial remand, is certainly less costly because it avoids delay.

133. Cf. Findings of the Board of Supervisors of Sacramento County in the Matter of the Certification of the Environmental Impact Report for the Laguna Community Plan at 4 (Dec. 7, 1977) (regarding diminished groundwater resources: "[t]he impact is not the result of the decision to urbanize the Laguna Creek area but is a result of the need for additional residential development regardless of where in the County the development takes place. The diminution is caused by demand for groundwater regardless of the location of the demand.").

134. A potential problem is that findings of infeasibility may not be prepared until after thc EIR is completed. In that case, the agency might devote considerable effort to studying offsite alternatives for ineeting goals other than those ultimately found to inake the originally proposed alternatives infeasible. Cf. 14 CAL. Admin. Code $\$ 15143(b)$ (May 10, 1980) (the ElR should describe "the reasons why the project is being proposed, notwithstanding [its] effect. . . .").

135. Nor will studies of offsite alternatives poimtlessly duphicate studies commissioned in connection with existing zoning plans. These earher studies may be summarized in the EIR. See Cal. Pub. Res. Code $\$ 21061$ (West 1977).

In zoning the area, the local government should already have decided which locations are best suited for what kinds of uses and should already have considered the environmental impacts of its zoning play by preparing an EIR on the plan. While the present zoning may represent a recent atteinpt at comprehensive planning, it may be outdated or it may be the result of a politically motivated, localized rezoning, or of a planning program that ignored regional concerns. Furthernore, even if the zoning was the result of a comprehensive planning prograin, it is unlikely that the site-specific or project-speeific impacts of development were considered in detail. Even if they were considered, public scrutiny and interest in the impacts of development are likely only at the time a specific development is proposed. Thus, while the EIR on the proposed devclopment might incorporate the discussion of alternative sites contained in the ElR prepared for the zoning 
If agencies fail to conduct the required studies, courts may remand for consideration of additional alternatives. Such remands might be criticized on the grounds that they delay projects without yielding environmental improvements, since the agency is likely to reapprove the project on remand. However, a procedural remand may result in the abandonment of the proposed project, because the resulting delay, in combimation with continumg imflation, has made the project unprofitable. ${ }^{136}$ Or the remand may result in modiflcation of the project, because the project proponent finds it better to compromise than to suffer additional delay and the risk of further hitigation. ${ }^{137}$ While this delay may be unfortunate because it is costly, it is the result of the agency's own failure to conduct the required studies. Furthermore, the delay may well result in environmentally superior outcomes. ${ }^{138}$

\section{Remand for a More Adequate Explanation of the Agency Decision}

Another procedural tactic that inight be used to encourage compliance with the policy of the 1976 amendments to encourage environmentally superior alternatives is a remand because of madequate explanation of the agency's decision. Several sections of the State EIR Guidelines require adequate support for the agency's decision. Section 15089 of the Guidelines ${ }^{139}$ notes that the courts have overturned deci-

plan, the public's opportunity to challenge the propriety of the development should not be foreclosed simply because the question was considered without much pubhic imput at an earlier date.

Cf. CAL. Pub. Res. Code $\S 21080.7$ (West Supp. 1980), which, under certain circumstances, allows a public agency to approve a project that is consistent with a "specific plan" without preparing a new EIR. The specific plan inust have been adopted no more than five years earlier. An EIR must have been prepared on the specific plan, an EIR "sufficiently detailed so that the signifcant adverse effects of the project ... and measures necessary to mitigate or avoid any such effects can be determined. . . " $\$ 21080.7$ (a)(1)(iv). Also, the project must involve the provision of llousing or neighborhood commercial facilities within an already urbanized area. This new section will avoid duplicative studies. However, simce the agency still must make the findings required by CAL. PuB. Res. CODE $\S 21081$ and file a notice of its decision with the county clerk, this provision will not prevent a court challenge to the agency's decision to approve the project.

136. Consider the history of the Storm King Pumped Storage Power Plant, which was tied up in litigation for years. See, e.g., Sceuric Hudson Preservation Conference v. Federal Power Comm'n, 453 F.2d 463 (2d Cir. 1971), cert. denied, 407 U.S. 926 (1972). This project never advanced beyond an abortive start on construction, New York Timies, Feb. 25, 1979, § 4, at 16, col. 1, despite ultimate approval by the courts.

137. If the project is eventually built, the delay will have imcreased its cost. The developer may pass some of these added costs on to the consumer. This might reduce the deterrent effect that the threat of litigation and delay might otherwise have on a developer contemplating an environmentally unsound project. However, these added costs may make the completed project less competitive.

138. Similarly, the delay produced by other kinds of procedural remands may also yield environmentally desirable results.

139. 14 CaL. ADMIN. CODE $\$ 15089$ (May 10, 1980):

Statement of Overriding Considerations.

(a) CEQA requires the decision maker to balance the benefits of a proposed project against its unavoidable environmental risks in determining whether to approve the pro- 
sions to approve environmentally dainaging projects where agencies have not explained the reasons for their decisions. ${ }^{140}$ Section $15146^{141}$ requires that the final EIR explain "in detail" why significant suggestions inade by commentators on the draft EIR were not accepted. ${ }^{142}$ Section $15088^{143}$ of the Guidelines requires a written finding under section 21081 of the Act $^{144}$ for each significant effect identified in the EIR, and requires each of those findings to be supported by "substantial evidence in the record" and to be accompanied by "a statement of the facts supporting [the] finding."

The City of Livermore's approval of a Master EIR for Residential

ject. Where agencies have taken action resulting in environmental damage without explaining the reasons which supported the decision, courts have invalidated the action.

(b) Where the decision of the public agency allows the occurrence of significant effects which are identified in the final EIR but are not initigated, the agency must state in writing the reasons to support its action based on the final ElR and/or other imformation in the record. This stateinent may be necessary if the agency also makes a finding under Section $15088(a)(2)$ or $(a)(3)$.

$$
\text { ... }
$$

See note 143 infra for text of $\$ 15088(a)$

140. For an example of such a case, see Burger v. County of Mendocino, 45 Cal. App. 3d 322, 119 Cal. Rptr. 568 (1st Dist. 1975), discussed at note 36 supra and note 200 infra.

141. 14 CAL. ADMIN. CoDE $\$ 15146($ b) (May 10, 1980) reads:

The response of the Lead Agency to comments received may take the form of a revision of the Draft ElR or may be an attachment to the Draft EIR. The response shall describe the disposition of significant environmental issues raised (e.g., revisions to the proposed project to mitigate anticipated inpacts or objections). In particular, the major issues raised when the Lead Agency's position is at variance with recommendations and objections raised in the comments must be addressed in detail giving reasons why specific comments and suggestions were not accepted.

142. Under CEQA, the agency first prepares a Draft EIR. This is opened to comment from other government agencies and the public. The Final EIR includes inaterial developed for the Draft EIR as well as responses to comments made on the Draft EIR. 14 CAL. ADMIN. CodE $\S 15085$ (May 10, 1980). See also id. § 15027.

143. 14 CAL. ADMIN. CoDE $\S 15088$ (May 10, 1980) reads in part:

(a) No public agency shall approve or carry out a project for which an environmental impact report has been completed which identifies one or inore significant effects of the project unless the public agency makes one or more of the following written findings for each of those significant effects, accoinpanied by a statement of the facts supporting each finding.

(1) Clianges or alterations have been required in, or incorporated into, the project which mitigate or avoid the significant environmental effects thereof as identified in the final EIR.

(2) Such changes or alterations are within the responsibility and jurisdiction of another public agency and not the agency making the finding. Such changes liave been adopted by such other agency or can and slould be adopted by such other agency.

(3) Specific economic, social, or other considerations make infeasible the mitigation measures or project alternatives identified in the final EIR.

(b) The findings required by subsection (a) shall be supported by substantial evidence in the record.

(c) The finding in subsection (a)(2) shall not be made if the agency making the finding lias concurrent jurisdiction with another agency to deal with identified feasible mitigation measures or alternatives.

Subsections (d)-(e) of $\$ 15088$ are discussed at text accompanying notes 86-88 supra.

144. CAL. Pub. Res. CODE $\$ 21081$ (West 1977), quoted at note 34 supra. 
Development ${ }^{145}$ illustrates an arguably inadequate explanation of agency action. The Bay Area Pollution Control District, commenting on the draft EIR, ${ }^{146}$ made several suggestions for reducing the impact of further residential development in Livermore on the already bad air quality in the Livermore-Amador Valley. One of those suggestions was to substitute a development plan with "higher densities and . . . a [development] pattern which is nore easily served by transit or other modes of travel than the auto." 147 The district suggested providing commercial areas close to high density residential areas in order to cut down on automobile trips. The city's response was very brief: "The higher densities were considered by the City of Livermore during the adoption of the General Plan in 1976. The city chose to develop a lower density im order to retain the present character of the community." 148 This response could be found not to explain "in detail," as required by section 15146 of the Guidelines, "why" the city rejected the suggestion. ${ }^{149}$ Retaming the present sprawling character of the community is, of course, imcompatible with higher density development. However, the response did not explain why retaining the character of the community was thought to be inore important than alleviating a serious air pollution problem, especially smce many people outside of the community will suffer from the air pollution created. Nor did the response explaim why the city felt bound by its prior decision. ${ }^{150}$

A court considering Hayward's 1979 rezoning of part of Charles Soda's property that had been im an agricultural preserve, might well have remanded for additional explanation. The City of Hayward rezoned a portion of the Soda property for residential development, even

145. City of Livermore Planning Department, Final EIR on Residential DevelopMENT IN THE CITY OF LIVERMORE TO THE YEAR 2000 (1978) (filed with Alameda County Clerk as an attachment to [Livermore] Notice of Determination [required by CEQA]) [hereinafter cited as LIVERMORE MASTER EIR].

146. Letter from Bay Area Pollution Control District to City of Livermore Planning Department (Aug. 31, 1978), reprinted in LIVERMORE MASTER EIR, supra note 145.

147. Id.

148. City of Livermore Planning Department, Staff Responses [to letter froin Bay Area Pollution Control District], LIVERMORE MASTER EIR, supra note 145.

149. See text of 14 CAL. ADMIN. CODE $\$ 15146($ b) (May 10, 1980), quoted at note 141 supra.

150. The city's explanation of its decision might also be found inadequate under $\$ 15089$ of the Guidelines because it failed to explain how the city balanced the competing considerations. See 14 CAL. AdmIN. Code $\S 15089$ (May 10, 1980), quoted at note 139 supra: However, an explanation of how the city balanced the coinpeting considerations may go beyond what is explicitly required by $\S 15089$, insofar as that section is based on Burger v. County of Mendocino, 45 Cal. App. 3d 322, 326, 19 Cal. Rptr. 568, 570 (1st Dist. 1975). See notes 36, 67 supra. The Burger court overturned the county's approval of a motel project because the county failed to explaim what factors outweighed the adverse environmental effects of building the motel. The City of Livermore, however, explained that it thought retaining the character of the community more important than reducing air pollution. Livermore only failed to explain why it thought the one more important than the other. 
though the EIR suggested the availability of alternative sites for additional housing. ${ }^{151}$ Hayward approved the rezoning because it "would provide additional housing of a type much in demand," 152 although the "deinand" was for environınentally unsound, sprawling, hillside subdivisions. A court might have been able to remand for failure to document the delnand, because section 15088(b) of the Guidelines requires "substantial evidence in the record" to support a finding that overriding social considerations make an alternative infeasible. ${ }^{153}$ Or a court might have remanded, under section 15089 of the Guidelines and parallel case law, for failure to show that people were unwilling to buy less environmentally destructive housing or for failure to explain why the existence of the "deinand" justified such an unsound planning decision.

The findings of the California Public Utilities Commission (PUC) in approving an expanded water supply for the Monterey area ${ }^{154}$ also illustrate a failure to coinply with the explanatory requirements imposed by the State EIR Guidelines. Section 15088(a) of the Guidelines requires one of the three findings set out in section 21081 of the Act ${ }^{155}$ to be made for each significant effect of the project identified in the EIR. ${ }^{156}$ No such written findings were made, although the PUC noted adverse effects on groundwater levels in the Carmel Valley and adverse effects of the growth that would result from providing an expanded water supply. The first of the possible findings set out in section 21081 is that the adverse effects of the project have been mitigated or avoided. No mitigation ineasures were imposed by the PUC in this case. ${ }^{157}$ Another possible finding is that mitigation measures or project alternatives are infeasible. The PUC mentioned several possible alternatives. While the PUC decision implied that the no-project alternative was infeasible because it would have required continued water rationing and

151. See Lewis \& DeBonis, City of Hayward threatens open space state-wide, Yodeler Envt'l News, April 1979, at 2, cols. 1, 4; Notice of Determination [required by CEQA] regarding Zone Change Application \#70-2/Tract 4008 (Jan. 16, 1979) (filed by City of Hayward with Alameda County Clerk Feb. 8, 1979 [hereinafter cited as Hayward Zone Change Notice of Determination].

The National Park Service has even studied the property for its open space valuc. Lewis \& DeBonis, supra, at 2, col. 3.

The Sierra Club has been litigating the cancellation of the agricultural preserve covering this portion of the Soda property. The Court of Appeals found no evidence in the record that other sites were available for lousing. It found only conclusionary testimony that somewhere nearby, "otherwise undescribed and unlocated," there was available land. Sierra Club v. City of Hayward, 107 Cal. App. 3d 127, 134 (1st Dist. 1980), hg. granted, Aug. 21, 1980.

152. City of Hayward, Statement of Overriding Considerations, attached to Hayward Zone Change Notice of Determination, supra note 151.

153. See 14 CAL. AdmiN. Code $\$ 15088$ (May 10, 1980), quoted at note 143 supra.

154. PUC Decision: Cal-Am Water Co., supra note 62.

155. Cal. Pub. Res. Code $\$ 21081$ (West 1977), quoted at note 34 supra.

156. 14 CAL. ADMIN. CODE $\$ 15088$ (May 10, 1980), quoted at note 143 supra. The Guidelines further clarify the requirements of $\$ 21081$. See text accompanying notes 159,161 infra.

157. PUC Decision: Cal-Am Water Co., supra note 62, Finding 5, at 11. 
a moratorium on new customers, ${ }^{158}$ it in no way explained why the wastewater reclamation alternative and the stabilization of water demands alternative were infeasible. The other possible finding under section 21081 of the Act is that changes or alterations in the project are "within the responsibility and jurisdiction of another public agency." 159 The PUC did note that "planning for growth is a local function."160 However, section 15088(c) of the Guidelines provides that the finding that another agency has jurisdiction "shall not be inade if the agency making the finding has concurrent jurisdiction . . . to deal with . . . alternatives." 161 If agencies with concurrent jurisdiction could excuse their failure to impose alternatives, by each claiming that the other was responsible for impleinenting the alternative, little might get done. Since the unavailability of water was a key factor limiting growth in the area, and since the PUC arguably had the power to decide how much water should be provided to the area, ${ }^{162}$ it would appear to have had concurrent jurisdiction with the local governments in implementing a slow growth alternative. ${ }^{163}$ Thus, the PUC's decision to approve the project despite its impact was not supported by any one of the required findimgs.

As the Laurel Hills, Livermore, Hayward, and Monterey area examples illustrate, agencies do make procedural errors. Procedural remands in such cases may encourage agencies to reach environmentally correct decisions. The procedural reinand, by pinpointing the agency's failure to study or explain, should suggest to the agency where it nay have made a substantive error. ${ }^{164}$ In addition, because remands are accompanied by delay, environmental improveinent may result. ${ }^{165}$

158. The PUC had to choose among growth, no growth, and limited growth alternatives for the Monterey area. While it clearly chose the contimued growth option, its opinion nowhere explained why that option was preferred. Rather, the opinion seems to have assumed that growth ought to continue. Thus, growth which was identified as an adverse effect of the project seems also to have been the justification for approving the project in spite of the adverse effects. Some additional explanation would seem to have been in order. See 14 CAL. ADMIN. CoDE $\$ 15089$ (May 10, 1980), quoted at note 139 supra.

159. Cal. Pub. Res. Code $\$ 21081$ (b) (West 1977).

160. PUC Decision: Cal-Am. Water Co., supra note 62, Finding 5, at 11.

161. 14 Cal. AdmiN. Code $\$ 15088$ (c) (May 10, 1980).

162. See CAL. PUB. UTIL. Code $\$ 762$ (West 1975) (PUC shall order additions to facihities which "ought reasonably to be made") (emphasis added). But see CAL. PUB. UTIL. CODE $\$ \S 8201-$ 8202 (West 1965 \& Supp. 1980) (requiring the PUC to ensure that any water company having a franchise to use city streets adequately serve the inhabitants of the city).

163. Furthermore, the PUC had jurisdiction to impose any system of water allocation that might have been required to impleinent such a slow growth alternative. See id. $\S 2708$ (West 1975).

164. In addition, the threat of procedural remands may encourage agencies to study alternatives and more carefuly consider their decisions, mcreasing the likelihood of environmentally sound outcomes.

165. See text accompanying notes 136-37 supra. 
However, because procedural remands only encourage the agency to correct its substantive errors, they are not the ideal technique for enforcing the statutory policy. ${ }^{166}$

\section{B. Quasi-Substantive Review}

While botll of the above-mentioned procedural remands may be used by courts interested only in procedural integrity, they also may be used selectively, i.e., quasi-substantively, by courts interested in enforcing the statutory objectives. In a quasi-substantive remand the court decides to reinand, at least in part, because the agency's approval is substantively dubious, but uses accompanying procedural errors as the basis for its opinion. ${ }^{167}$ In its opinion, lowever, the court may suggest what it believes to be the proper substantive result. ${ }^{168}$

If the courts can require agencies to study numerous alternatives or explain their decisions thoroughly, then courts should generally be able to find some procedural error. ${ }^{169}$ Even if the courts set relatively high standards for "procedural" coinpliance, they might ignore procedural errors where the substantive decision seeins acceptable. Then, they would reinand only where the procedural lapse is itself quite serious or where the agency seems to have reaclied the wrong decision. ${ }^{170}$ Because the resulting delay liurts, as previously discussed, such "procedural" reinands can produce substantive results. ${ }^{171}$

Because procedural remands burden projects with additional costs and delay, even courts sympathetic to environmental concerns may want to use these remands only quasi-substantively, that is, when they have reason to believe the agency has reached an incorrect decision. ${ }^{172}$ For example, a court may not want to remand for study of offsite alter-

166. See text accompanying notes 60-63 supra.

167. The most extreme form of quasi-substantive review occurs when courts "up the procedural ante" by continually inventing new, stricter procedural requirements with which agencies must comply. A court is not so likely to invent these as to borrow them from some other law and impose them on the agency as a matter of statutory construction. A less extreme form of quasisubstantive review is for the courts to apply procedural requirements strictly in cascs where they disagree with the agency's decision; more loosely, when they agree.

168. This ability to suggest where the agency has made substantive erors and what would be the better solution lies at the heart of the quasi-substantive approach. See text accompanying note 164 supra. For example, when a court indicates what alternatives an agency has improperly failed to consider, it may thereby suggest which alternatives it thinks the agency should have preferrcd. Consider whether County of Inyo v. City of Los Angeles, 71 Cal. App. 3d 185, 139 Cal. Rptr. 396 (3d Dist. 1977) attempted to do just that.

169. See Residents Ad Hoc Stadium Com. v. Board of Trustees, 89 Cal. App. 3d 274, 285, 152 Cal. Rptr. 585, 592 (3d Dist. 1979) (it is doubtful that any agency could produce a perfect EIR).

170. The more substantively erroneous a decision appears to be, the harder it will be to explain the decision. Therefore, courts could inore easily find the supporting explanation inadequate.

171. See text accoinpanying notes 136-38 supra.

172. Even so, courts are likely to remand when a procedural requirement imposed by the Act 
natives unless the evidence suggests the existence of an alternative site so far superior that it warrants the added costs. Thus, although these remands may appear to estabhish uniform procedural rules for all cases, courts may view them as tactical weapons.

If these procedural tools are employed selectively, under a quasisubstantive approach, they should not generate excessive paperwork, require consideration of a seemingly limitless number of alternatives, or result in wholesale frustration of development. ${ }^{173}$ For example, under a quasi-substantive approach, agencies would only be required to study those alternatives likely to solve serious problems. ${ }^{174}$ Quasisubstantive review aims the relief where there are substantive problems.

Courts, however, may be reluctant to use these remand techniques quasi-substantively. They may see precedent as limiting how far courts can go in requiring agencies to explain their decisions thoroughly and as limiting the number of alternatives courts can require an agency to consider. Administrative findings have been said to be adequate if "/ijn the absence of a statutory requirement . . . they are sufficient to apprise . . . the courts of the bases for the administrative action." 175 Similarly, responses to comments on a draft EIR lave been held sufficient, even though they were "not exhaustive," because they evinced "good faith and reasoned analysis." "176 Thus, courts may be reluctant to reverse for inadequate explanation unless the agency entirely fails to make the findings specifically required by section 21081 of $\mathrm{CEQA}^{177}$ and sections 15088 and 15089 of the Guidelines, ${ }^{178}$ or unless the agency fails to explain why it rejected "specific comments and suggestions" as required by section 15146 of the Guidelines. ${ }^{179}$ Furthermore, the court of appeal

or the Guidelines has clearly been violated, e.g., where the agency has completely failed to explain its decision. See text accompanymg notes 177-79 infra.

173. Cf. Jordan, Alternatives Under NEPA: Toward an Accommodation, 3 EcoLoGY L.Q. 705, $737-40$ (1973) (discussing increase in paperwork without increase in environmental protection caused by requiring the agency to consider a plethora of alternatives).

174. Even if the courts only review these agency decisions for purely procedural comphance, the number of alternative sites that ought to be studied is limited. See note 132 and accompanying text supra.

175. San Francisco Ecology Center v. City and County of San Francisco, 48 Cal. App. 3d 584, 596, 122 Cal. Rptr. 100, 108 (1st Dist. 1975) (einphasis added); accord, Bakman v. State Dep't of Transp., 99 Cal. App. 3d 665, 688, 160 Cal. Rptr. 583, 595 (3d Dist. 1979).

176. San Francisco Ecology Center v. City and County of San Francisco, 48 Cal. App. 3d 584, 596, 122 Cal. Rptr. 100, 108 (1st Dist. 1975).

177. CAL. PUb. Res. Code $\$ 21081$ (West 1977), quoted at note 34 supra.

178. 14 CAL. AdMIN. CODE $\$ 15088$ (May 10, 1980), quoted at note 143 supra, id. $\$ 15089$, quoted at note 139 supra.

179. Id. $\S 15146($ b) (May 10, 1980), quoted at note 141 supra.

Cf. People v. County of Kern, 62 Cal. App. 3d 761, 133 Cal. Rptr. 389 (5th Dist. 1976) (finding the agency's responses to comments inadequate under $\S 15146(\mathrm{~b})$ ). Even though the county did commeut on the water supply problem, the court found the county's response inadequate 
has said that "[t]he discussion of alternatives need not be exhaustive ... the requirement as to the discussion of alternatives is subject to a construction of reasonableness." 180 Thus, courts may be reluctant to order agencies to study additional alternatives if they have studied the obvious alternatives. ${ }^{181}$ These holdings, of course, do not set a definite limit on how far courts may go in requiring a detailed explanation or the study of additional alternatives. The limits they set depend on what particular courts find to be "reasonable" or "in good faith."182 Nevertheless, courts that are unwilling to review agency approvals quasi-substantively are likely to cite these holdings to support their decisions upholding agency approvals.

Courts may be reluctant to employ quasi-substantive review, either because they believe that courts should not review the "wisdom" of agency decisions ${ }^{183}$ or because they feel that it is illegitimate to vary procedural requirements depending on whether or not a substantive error has been committed. If courts can only require a simgle level of procedural comphance for all cases, they may choose to keep that level low in order not to routimely overturn agency approvals of reasonable developments. However, requiring only a low level of comphance may

because the agency had not "squarely faced" the problem in deciding whether to approve the project. Id. at 773, 133 Cal. Rptr. at 397 . The court found that the county's response to comments was not a "good faith, reasoned analysis." Id. at 770, 133 Cal. Rptr. at 395, quoting People v. County of Kern, 39 Cal. App. 3d 830, 842, 115 Cal. Rptr. 67, 75 (5th Dist. 1974), quoting Silva v. Lynn, 482 F.2d 1282, 1285 (1st Cir. 1973).

180. Residents Ad Hoc Stadium Comm. v. Board of Trustees, 89 Cal. App. 3d 274, 286, 152 Cal. Rptr. 585, 593 (3d Dist. 1979).

181. "[When there is a good-faith effort to produce information sufficient to permit a rcasonable choice of alternatives] an EIR does not become vulnerable because it fails to consider in detail each and every conceivable variation of the alternatives stated." Id. at 287-88, 152 Cal. Rptr. at 594. However, County of Inyo v. City of Los Angeles, 71 Cal. App. 3d 185, 203, 139 Cal. Rptr. 396, 408 (3d Dist. 1977) overturncd an agency ElR, noting that "it is doubtful whether an EIR can fulfill CEQA's demands without proposing so obvious an alternative."

Furthermore, 14 CAL. Admin. CODE $\$ 15143$ (d) (May 10, 1980) requires the ElR to "[d]escribe all reasonable alternatives to the project, or to the location of the project, which could feasibly attain the basic objectives of the project" (emphasis added).

Cf. Big Rock Mesas Property Owners Ass'n v. Board of Supervisors, 73 Cal. App. 3d 218, 226-27, 139 Cal. Rptr. 445, 449-50 (2d Dist. 1977) (EIR need only describe alternatives to the project as a whole; alternatives only to the most environmentally damaging aspect of the project need not be considered).

Jordan, supra note 173 , at 739 , notes that courts are unlikely to order consideration of numerous alternatives. Environmentalists instead try to get the court to order the agency to consider one more.

182. See note 179 supra.

183. Courts may view the substantial evidence test as intended to prevent courts from reviewing the "wisdom" of agency decisions. However, this Comment concludes that the substantial evidence test should not be construed to prevent courts from reviewing agency findings of infeasibility as a matter of law, and should not be construed to prevent courts from overruling the agency's decision as to what makes a project "successful." See text accompanying notes 188-95, 232-35 infra. 
inhibit effective review of agency decisions. Quasi-substantive review, on the other hand, avoids routine reversals while helping to secure substantive compliance. Since CEQA imposes both procedural and substantive requirements on agency decisionmaking, it is arguably not improper for the courts thus to coinbine their procedural and substantive responsibilities and review agency decisions quasi-substantively. ${ }^{184}$

Quasi-substantive review, however, has its limits. An agency may respond to a quasi-substantive remand, not by changing its decision, but by changing only its explanation. ${ }^{185}$ If courts are only willing to exercise their substantive responsibilities quasi-substantively, the realization that agencies may stand by their original decisions may discourage courts from atteinpting quasi-substantive remands. ${ }^{186}$ Courts inay be especially reluctant to delay a project further and increase its costs by ordering a second "procedural" reinand when the agency did not reach the decision the court wanted it to after a first remand. ${ }^{187}$

\section{Review of Infeasibility as a Matter of Law}

Effective and genuinely substantive enforceinent of the 1976 amendments to CEQA would be possible if the courts were to review the feasibility of modified or alternative projects as a "inatter of law." The substantial evidence test applies to "questions of fact." "Questions of law," however, are for the court. A finding of "infeasibility" involves the application of a rule of law to the facts, and thus presents a mixed question of law and fact. The court could, theoretically, either defer to the agency by employing the substantial evidence test or instead decide the legal issues in this mixed question by reviewing thein as a matter of law. ${ }^{188}$ Matter of law review is appropriate because a

184. Procedural and substantive requirements overlap to some extent. See note 170 supra.

185. Compare text accompanying notes 60-63 supra (procedural remands require only improved explanation) with text accompanying notes 136-38 supra (but delay hurts).

186. If a court were willing to remand on exphcitly substantive grounds, it might do so either initially or after a first, quasi-substantive remand had failed to achieve its purpose. Courts, however, may be unwilling to engage in explicitly substantive review, precisely because it exphcitly asserts the court's authority to review the agency's judgment. Quasi-substantive review at least purports to confine the courts to reviewing agency compliance with procedural requirements, a traditional area of judicial expertise. Quasi-substantive review inight also seem preferable to a court that was unsure of its substantive power under the 1976 amendments.

187. Compare Scenic Hudson Preservation Conference v. Federal Power Comm'n, 453 F.2d 463 (2d Cir. I971) (court declines to remand to agency a second time), cert. denied, 407 U.S. 926 (1972) with County of Inyo v. City of Los Angeles, 71 Cal. App. 3d 185, 139 Cal. Rptr. 396 (3d Dist. 1977) (court rejects EIR written in response to its 1973 writ of mandate) and People v. County of Kern, 62 Cal. App. 3d 761, 133 Cal. Rptr. 389 (5th Dist. 1976) (court remands to agency for a second time).

188. See Sive, Some Thoughts of an Environmental Lawyer in the Wilderness of Administrative Law, 70 Colum. L. REv. 612 (1970). Sive stresses the desirability of having mixed law and fact determinations reviewed as a matter of law when environmentalists are challenging an agency decision. Robie, Recognition of Substantive Rights Under NEPA, 7 NAT. RESOURCES LAW. 387, 
key factor in deciding whether or not an alternative is feasible is the weight to be given to conflicting values, which is not a factual determination. ${ }^{189}$ While the legislature no doubt intended to give agencies some discretion in balancing values, this Comment argues that a grant of unlimited discretion was not intended.

If the substantial evidence test were to require the court to defer to whatever goals the agency has selected, then substantive review of the agency decision might be nearly impossible. If the agency could find an alternative infeasible if it did not ineet 100 percent of every public and private goal set for a project, then it could find almost any change in a project infeasible, by setting up numerous, narrow goals for the project to fulfill. Yet CEQA declares that, "[e]ach public agency shall mitigate or avoid the significant effects on the environment of projects it approves . . . whenever it is feasible to do so." 190 Thus, CEQA imposes a mandatory substantive duty to disapprove projects when environinentally superior alternatives or mitigation measures are feasible. ${ }^{191}$ In order to prevent this section of CEQA from becoming meaningless, ${ }^{192}$ the courts should develop rules of law limiting the agency's choice of goals; they should review agency findings of infeasibility as a matter of law. ${ }^{193}$

$423,425-26$ (1974), also discusses the possibility of courts deciding issues normally.considered to be "factual" as "inatter[s] of law."

189. See notes 54-56 and accoinpanying text supra.

190. Cal. Pub. Res. Code $\S 21002.1$ (b) (West Supp. 1980) (emphasis added).

191. By imposing this substantive duty on the agency and by providing for judicial review of the agency decision, the legislature has authorized substantive review of the agency decision. This Comment argues that review of agency findings of infeasiblity as a inatter of law is essential to make this substantive review a reality.

192. "Courts slould construe all provisions of a statute together, significance being given-if possible- to every word, phrase, sentence, and part of an act in pursuance of the legislative purpose. Turuer v. Bd. of Trustees, $16 \mathrm{Cal}$. 3d 818, 826-27, 548 P.2d 1115, 1120, 129 Cal. Rptr. 443, 448 (1976).

193. A matter of law approach is not barred by the judicial review sections of CEQA, even though they provide for substantial evidence review. Quasi-legislative decisions may be ovcrturned for abuse of discretion "if the agency has not proceeded in a nnanner required by law or if the determination or decision is not supported by substantial evidence." CAL. PUB. RES. CODE $\S 21168.5$ (West 1977) (einplasis added). CaL. Pub. Res. CODE $\$ 21168$, governing review of quasi-judicial decisions, mcorporates by reference $\S 1094.5$ of the Code of Civil Procedure. Section 1094.5 also provides that "[a]buse of discretion is established if the respondent has not proceeded in the manner provided by law. ..." CAL. CIv. Proc. Code $\S 1094.5(b)$ (West 1980). The substantial evidence test applies only "[w]here it is claimed that the findings are not supported by the evidence. . . ."Id. $\S 1094.5(\mathrm{c})$.

Even though \& 1094.5(c) sometimes allows the courts to exercise their independent judgment in reviewing claims that findings are not supported by the evidence, $\$ 21168$ of the $C_{A L}$. PUB. REs. CODE provides that im all cases "the court shall not exercise its independent judgment on the evidence" (emplasis added). Thus, $\S 21168$ 's prohibition on the use of independent judgment applies only to factual findings. Since a finding of infeasibibty presents the court with a inixed question, see text accompanying note 54 supra, the courts shoud remain free to decide the legal questions. 
This Comment discusses several matter of law approaches that courts could use to limit the agency's ability to find alternatives infeasible. The first two would establish general rules of law preventing an agency from insisting that a modified project quantitatively achieve 100 percent of each of the proposed project's goals. ${ }^{194}$ Although CEQA does not detail the rules of law to be applied by the courts in enforcing its mandate, the judiciary should formulate rules of law in order to give effect to the substantive provisions of the Act. In Friends of Mammoth v. Board of Supervisors, the California Supreme Court ruled that CEQA is "to be interpreted in such manner as to afford the fullest possible protection to the environment . . ." 195 Rather than formulating general rules of law, the courts might implement Mammoth's directive by reviewing agency findings of infeasibility on a case-by-case basis as a inatter of law. Under this third approach courts would review, as a question of law, the balance struck by the agency between environmental values and coinpeting economic or social goals. This approach might go so far as to allow a court to find an alternative feasible even though a particular goal was coinpletely unmet.

\section{The Profitability Standard}

Under the first proposed rule of law approach, the judiciary would limit the extent to which agencies can find projects infeasible because of their failure to meet private goals. Courts could limit claims of private infeasibility ${ }^{196}$ by imposing a profitability standard. There are at least two possible formulations of a profitability standard. Under one, modified or alternative projects would not be considered privately infeasible if they were capable of yielding a profit sufficient to induce an

194. Once the courts have enunciated these general rules, agencies would be expected to apply them in deciding whether or not an alternative is feasible. Insofar as these rules set out definite standards, courts could fairly easily review agency decisions for compliance. Thus, the substantial evidence test might be sufficient for reviewing an agency's finding that an alternative did not meet the proposed profitability standard. See note 222 infra.

195. 8 Cal. 3d 247, 259, 502 P.2d 1049, 1056, 104 Cal. Rptr. 761, 768 (1972).

[T] he Legislature intended [C]EQA to be interpreted in such manner as to afford the fullest possible protection to the environment within the reasonable scope of the statutory language. ... Once a particular legislative intent has been ascertained, it must be given effect "even though it inay not be consistent with the strict lettcr of the statute."

Id. (citation omitted). Friends of Mammoth interpreted CEQA's statutory language very hiberally. See note 28 and accompanying text supra.

196. Developers would most hkely raise such claims in the first place. Since the approval of projects under CEQA is discretionary with the agency, Cal. PuB. RES. CoDE $\$ \$ 21002.1$ (c), 21080(a) (West Supp. 1980), the Act does not require the agency to approve a project when the promoter claims unprofitability. See note 262 infra. However, if the agency chooses to approve a project because denial would impair the profitabihty of the project, the courts will have to review such claims. 
investor to invest his funds in the project. ${ }^{197}$ Under the other, a project would not be considered privately infeasible if the landowner were left with some profitable use for his land. ${ }^{198}$

Even apart from any claim of "private infeasibility," a private project may be infeasible because it is incapable of being carried out. A private project is probably "[in]capable of being accomplished . . . taking imto account economic . . . factors" 199 if it is so unprofitable that no developer is likely to undertake it. ${ }^{200}$ Where a totally offsite alternative is proposed, that alternative may be profitable for a reasonable investor even if the owner of the originally proposed site is left with no profitable use for his land. But where at least part of the alternative consists of building a project on the original site, if the modified project is unprofitable for the original developer, there may well be a loss of public benefits, as the onsite portion of the project is unlikely to be constructed. Thus, an allegation of unprofitability might be used to sup-

197. This would require determination of an appropriate rate of return. This might be calculated by reference to typical rates of return on developments involving a similar degree of risk.

198. Although different, these two formulations overlap when the developer owns the land. One formulation measures the developer's profit, the other, the landowner's. However, the two formulations differ in that the one assumes further development of the land, while the other requires consideration of profitable uses not involving further development.

199. CAL. Pub. Res. Code § 21061.1 (West 1977) (defining "feasible").

200. See Foundation for San Francisco's Architectural Heritage v. City and County of San Francisco (City of Paris), 106 Cal. App. 3d 893, 911-12, 165 Cal. Rptr. 401, 411-12 (1st Dist. 1980), hg. denied, Aug. 21, 1980. Cf. note 130 supra (an alternative is infeasible if it is incapable of being accomplished in a successful manner-the Act makes no mention of the likelihood of its being accomplished). The idea that an unprofitable private development is infeasible because no developer is likely to undertake it perhaps explains some comments made by the court in Burger v. County of Mendoeino, 45 Cal. App. 3d 322, 326, 119 Cal. Rptr. 568, 570 (1st Dist. 1975). In Burger a developer who proposed to build a motel claimed that the environmentally superior alternative "was not feasible economically." Id. The court ignored that claim because there was "no evidence that reduction of the inotel from 80 to 64 units, or relocation of some units, would make the project unprofitable." $I d$. Thus the court seems to have equated economic feasiblity with profitability. The plaintiffs in Laurel Hills also seem to have equated infeasibility with unprofitability. See note 122 supra. These two sources suggest that a profitability standard could be used to limit claims of "private infeasibility."

The Michigan Court of Appeals in Wayne County Dep't of Health v. Olsonite Corp., 79 Mich. App. 668, 703-04, 263 N.W. 2d 778, 796 (1977), apphed an industry-wide standard of economic feasibility to requireınents imposed on industries under the Michigan Environmental Protection Act. Mich. Comp. Laws Ann. $\$ \S 691.1101-.1207$ (Supp. 1980). "[Requirements] may be economically feasible even though froin the standpoint of employers, they are financially burdensome and affect profit inargins adversely. . . . [Economically feasible requirements may result in] the economic demise of an einployer who has lagged behind the rest of the industry . . . and is consequently financially unable to coinply with new [requireınents] as quickly as other employers." Id., quoting Industrial Union Dep't, AFL-CIO v. Hodgson, 499 F.2d 467, 477-78 (D.C. Cir. 1974). Sucl an industry-wide standard may be more readily applicable to pollution control requirements imposed on all manufacturers (as in Olsonite) than to the highly individualized alternatives that might be required of a particular land developer. Nevertheless, by testing whether or not an alternative project is sufficiently profitable to attract investment funds, the standard discussed in this Comment does refer to a customary mdustry-wide rate of return rather than to the profit needs of particular developers. 
port claims of either private or public infeasibility. ${ }^{201}$ The proposed profitability standard could be used to judge both. ${ }^{202}$

A profitability standard would limit the kinds of private infeasibility that an agency could recognize, as well as the amount of profit considered necessary to make a project feasible. In the absence of such limits, developers or agencies might contend that the developer's inability to get everything he wants out of the alternative project makes that alternative unsuccessful and therefore infeasible. If an agency could find a modified private project infeasible simply because it failed to provide the developer with as much profit as he would have made on the original project or because the inodified project failed to embody the "development concept" of the original plan, then almost any change could be found infeasible. ${ }^{203}$ Only the most minimal changes or those that could be made with almost no cost could be required by a court. For exainple, a court would be unable to prefer an alternative to a residential subdivision plan that grouped the houses more closely together if the developer's mtention was to provide "spacious, gracious country livmg." If the courts were unable to scrutinize findings of imfeasibility in such cases, the statutory duty to prefer environmentally superior, feasible alternatives would be nearly unenforceable. A profitability standard would permit the courts to scrutinize these findings and substantively enforce the statutory duty.

A profitability standard limits but does not ignore claims of pri-

20I. This Comment will contend that even where a proposed alternative falls far short of fulfilling the goals set for a project so that the alternative seems publicly or privately infeasible, the alternative may nevertheless be feasible. When the environmental harm that would be caused by a project outweighs the benefits that would be produced by the project, an alternative that avoids that harm is successful, and therefore "feasible," even though it falls short of the original project goals. See text accompanying notes $232-41$ infra.

202. A profitability standard may not be appropriate for reviewing the feasibility of certain kinds of private projects. For example, a profitability standard is not likely to be helpful in judging the feasibility of projects constructed for charitable orgamizations or for an owncr's personal use. The standards sketched out above also may not be helpful in a case where the developer of the origmally proposed project does not own the site and an entirely offsite alternative is the preferrcd alternative. Even if the owner of the original site is left with soine profitable use for his land, the developer may have expended considerable sums in preparing plans that cannot now be used. In that case it is not clear whether or how the developer's profit expectatious should be protected. Cf. note 216 infra (discussing the problem of how inuch weight should be given to the price paid for land in computing the profitability of onsite alternatives). This Comment does not attempt to develop standards to deal with these particular situations.

203. See Foundation for San Francisco's Architectural Heritage v. City and County of San Francisco (City of Paris), 106 Cal. App. 3d 893, 165 Cal. Rptr. 401 (1st Dist. 1980), hg. denied, Aug. 21, 1980. In City of Paris, the agency found an alternative infeasible because it would "not meet the developer's marketing requirements" and would entail "substantially greater construction costs than the proposed project." Id. at 904, 165 Cal. Rptr. at 407 . The agency noted that these increased costs would be incurred whether the alternative was constructed by the project proponent or by a developer who preferred to construct the alternative. Id. The court generally approved the agency's findings. Id at 912-13, $165 \mathrm{Cal}$. Rptr. at 412 . 
vate infeasibility. The standard assumes that from the owner's or developer's perspective the factor that really makes a private development successful, and thus "feasible," is its ability to make money for him. And it provides an objective standard for determining how much of a profit makes a project successful. It would require the agency to impose a reasonable and limited increment of costs on a developer, when necessary, im order to protect the public's interest in the environment. 204

Where an agency rehies on private infeasibility to support its approval of a project, because it is unable to establish the public infeasibility of an environmentally superior alternative, ${ }^{205}$ the profitability standard may make substantive enforcement of the feasible alternative requirement possible. ${ }^{206}$ Consider the development of a housing tract whose developer proposes to channelize a stream that runs through the tract. The channelization would adversely affect a downstream wildlife area. Comments on the draft EIR suggest that the developer place the houses farther away from the stream and floodproof them, but the local agency approves the channehization notwithstanding this recommendation. Under a profitability standard, a court could order the local agency to disapprove the proposed development unless the suggested changes were incorporated, so long as the modified project would still be sufficiently profitable for the developer. ${ }^{207}$

It may be inuch easier for courts to overturn project approvals for failure to incorporate "mitigation ineasures," as in the example above, than for failure to require more substantial changes. ${ }^{208}$ Mitigation measures are likely to be less costly. Furthermore, where the recommended changes are relatively mimor, as in the channelization example above, there may not be any loss of public benefits. ${ }^{209}$ In that case there could be no claim of public infeasibility. Thus, courts generally

204. Because the profitability standard would be a legal rule applicable to all cases, it could be imposed by the courts as a matter of law. This would avoid $\$ 21168$ 's prohibition against the courts exercising their independent judgment "on the evidence." See note 193 supra.

205. For a discussion of standards for judging claims of public infeasibility, see text accompanying notes 223-31 infra.

206. An agency might also claim that an alternative was incapable of being carried out because it was so unprofitable that no one would undertake it. The profitability standard would also limit such claims.

207. This factual situation and the likelihood of a court's enforcing CEQA substantively under these circumstances were suggested by Marc Mihaly of the California Attorney General's office, March 1979.

208. Because there is no sliarp line between mitigation measures and inore substantial project changes, this Comment generally includes projects as modified by initigation measures within the term "alternatives." Nevertheless, it is sometimes lielpful to refer to the relatively more mimor changes as "mitigation measures." See notes 20,79 , and text following note 85 supra.

209. The greater the clianges, the more likely there is to be some loss of public benefits that could result in a claim of infeasibility. 
should be able to reverse agencies that approve projects without requiring mitigation measures, if those measures are economically and technically feasible, so long as the measures substantially reduce significant environmental impacts. ${ }^{210}$ With the profitability standard as a measure of economic feasibility, courts could substantively enforce the Act, at least where the proposed changes neither significantly alter the project nor inflate its cost to the poimt where it becomes unprofitable. ${ }^{211}$

A byproduct of applying the profitability standard is that it answers the objections of those who argue that a landowner has a legitimate economic expectation of being able to develop his property. CEQA does not require the courts to consider this expectation. An argument might be made, however, on grounds of economic fairness, that a landowner has reason to expect that a court will not reverse an agency's approval of his plan to develop in accordance with the existing zoning merely because some other site is better suited for that use. Of course, the agency might disapprove the proposal, and in any case, the owner has no vested right in the existing zoning. ${ }^{212}$ The owner might consider it especially burdensome, though, to be obliged to prove that environmentally superior offsite alternatives to a project are infeasible, where the owner's site is already zoned for the proposed use. ${ }^{213}$ If the court recognizes the owner's claim that he should be allowed to develop in accordance with the existing zoning, the court might be severely limited in requiring even relatively minor changes in the development, since zonimg ordinances typically set only a maximum density. ${ }^{214}$ For example, a court might be unable to eliminate from a subdivision a few

210. See text accompanying note 78 supra.

Cf. Memorandum to Claire T. Dedrick froin Norman E. Hill regarding Amendments to A.B. 2679 , at 2 (April 29, 1976) ("It]he bill would probably lead to more mitigation measures being adopted") (obtained froin the files of the California Resources Agency) (on file with the California Law Review).

211. Cf. Note, The Least Adverse Alternative, supra note 6, at 752 (agencies should be required to approve environmentally preferable alternatives that impose no additional costs, either monetarily or in ternis of lost benefits).

212. HFH, Ltd. v. Superior Court, 15 Cal. 3d 508, 512 n.2, 542 P.2d 237, 240 n.2, 125 Cal. Rptr. 365, $368 \mathrm{n} .2$ (1975) ("our courts have . . . . clearly and frequently rejected the position that landowners enjoyed a vested right in a zoning classification").

213. See text accompanying note 130 supra (discussing partially and totally offsite alternatives).

It might be argued that the burden is especially unfair because the agency with zoning authority is not attempting to rezone the property. However, that agency is also under a duty to avoid unnecessary environmental harm. CEQA requires local agencies to implement state-inandated environmental policies.

214. Zoning ordinances also frequently authorize a number of different uses for a given site, e.g., a shopping center or an apartment complex. The nost profitable use might be the shopping center, but it might also cause more environmental harm. If the court must validate an agency decision permitting a slopping center, it cannot insist upon a feasible alternative use. The profitability standard, by contrast, would allow the court to reverse the agency for not imposing an environmentally better, but somewhat less profitable, alternative. 
lots lying within a flood plain. Rather than allowing development to the inaximuin density allowed by the zoning, courts might refuse to "impose" 215 alternatives that do not permit a land use generally like that contemplated by the zoning ordinance. But that would prevent the courts from insisting that a different, environmentally superior site be developed first, even where at least part of the owner's parcel was evidently unsuited to the use for which it had been zoned. However, if the courts used a profitability standard to limit claims of infeasibility, they could "impose" soine additional costs on the developer to protect the environment, while still respecting his fairness claims to a profitable use of his land. The profitability standard would, for example, prevent courts from entirely prohibiting the developinent of an urban parcel merely because there are superior alternative sites for the proposed development.

The profltability standard, then, is a compromise. It does not ignore the economic expectations of the landowner; it ensures that the courts will leave him soine profitable use for his land. However, it does not recognize the claim that he should be allowed to develop in accordance with the existing zoning, no matter how environmentally mappropriate the zoning. It permits the courts to protect the environment, but not to the point of disregarding the landowner's expectations entirely. ${ }^{216}$

There are at least two structural problems with the profitabihty standard. First, the court's ability to impose environmental protection

215. Neither the court nor the agency actually "impose" an alternative on the project proponent. Rather, the proposed project is denied because of the existence of a feasihle alternative; the developer is free to proceed with the alternative or abandon the project. Nevertheless, this paper, as a kind of shorthand, occasionally speaks of courts or agencies "imposing" alternatives on developers.

216. One problem with the profitability standard is whether or how it should take account of the price paid for land. Consider the situation where a high, speculative price has been paid for rural land in anticipation of obtaining a zoning change. Suppose that the zoning change is granted, but then cliallenged in court. If the court includes the purcliase price of the land in figuring what uses of the land would be profitable, the court might well conclude that continued agricultural use would not. But then the court might be unable to prevent premature development in a rural area where agriculture is generally profitable. If, on the other liand, the price of land is never included in the computation, even the most mimimal use of expensive land in developed areas could be found to be a feasible and "profitable" alternative, so long as an investor would be willing to spend whatever additional sums were necessary to generate a profit.

It would not be an unconstitutional "taking" to ignore the purchase price and only allow a minimal use of the property. See Agins v. City of Tiburon, 24 Cal. 3d 266, 277, 598 P.2d 25, 31, 156 Cal. Rptr. 372, 378 (1979) ("taking" occurs only if the owner is deprived of "substantially all reasonable use of his property"), affd on other grounds, $100 \mathrm{~S}$. Ct. 2138, 2141 (1980) ("taking" occurs if regulation "denies an owner economically viable use of his land") (dictum).

Similar problems might arise where property las been down-zoned after purchase and the developer insists that he be permitted the maximum density allowed by the present zoning in order to recoup his investment. However, the courts' ability to enforce CEQA should probably not depend on the vagaries of a parcel's zoning history. 
measures would depend on the profitability of the project. A court would be able to require very hittle of a project that was only marginally profitable to begm with. There seems to be little reason why a margmally profitable developinent ought to be allowed to cause more environmental harm than a more profitable one. ${ }^{217}$ Second, the profitability standard does not consider whether the environmental benefits obtamed by impleinenting the modifications are worth the additional cost. And the most readily available tool for making this determmation, a cost-benefit ratio, is not well suited for the task. ${ }^{218}$ It may be very difficult to place a dollar value on the environmental benefits that would be destroyed by a proposed project. $^{219}$ Consider the stream channelization proposed as part of the housing development discussed above. The monetary value of the foregone benefits would be difficult to compute both because of uncertainty as to just how much damage would be done and because of the essentially non-monetary nature of the benefits a wildlife area provides. Furthermore, economic analyses discount long term losses of environmental benefits to present value even though the harm done may be irreversible or very costly to repair. Fimally, even if the damage to the wildlife area could be assigned a dollar value, that dollar value would represent harm done to the public, while the cost of avoiding that harm is a cost that would be borne by the developer and those who buy his houses. Thus, if the developer were able to avoid impleinenting the suggested changes because of an "unfavorable" cost-benefit ratio, he would benefit froin increased profits while the public would be forced to bear the "cost" of the damage to the wildlife area. ${ }^{220}$ In sum, claims that the benefits of altermg a project are not worth the cost will have to be reviewed by soine technique other than a cost-benefit ratio. The cost of inaking alterations in the project will need to be weighed against the seriousness of the environmental harm threatened. However, this Comment will argue that courts ought to review the agency's balance of costs and benefits qualitatively, without attempting to reduce all costs and benefits to monetary

217. Cf. Zucker, Environmental Right of Action-A Suggested Statute and Commentary, 7 HARv. C.R.-C.L. L. REv. 520, 546 n.114 (1972) (court-imposed environmental protection measures impose "prohibitive costs" if they raise a producer's costs above market price).

218. A cost-benefit ratio attempts to compare the dollar value of all the costs of a project with the dollar value of all the benefits derived from the project. In comparing alternatives, the additional benefits of an alternative should be compared with its additional costs. See Note, The Least Adverse Alternative, supra note 6, at 752-53.

219. See id., at 743-44, 753 (noting the difficulty of quantifying environmental harms); Note, supra note 62, at 201-06 (noting the difficulty of measuring environmental harms and putting a dollar value on them).

220. See Note, The Least Adverse Alternative, supra note 6, at 752 n.97 (imcome redistribution may be effected by the most cost-effective proposal). 
figures. ${ }^{221}$

Despite the difficulties involved in applying the profitability standard, it still represents a credible approach to setting reasonable limits on claims of private infeasibility. ${ }^{222}$ Although the courts have not yet formulated a standard for limiting claims of private infeasibility, these claims must be restricted in order for CEQA to be given adequate substantive effect.

\section{The Reasonable Percentage of Additional Public Costs Rule}

While the profitability standard would set a limit on claims of private infeasibility, that standard is generally irrelevant in reviewing claims of public infeasibility, ${ }^{223}$ because the latter are based on a failure to meet public goals rather than a failure, e.g., to inake a profit. ${ }^{224}$ It has been suggested that an increinental cost-benefit analysis might indicate which alternatives are publicly feasible. ${ }^{225}$ This approach would compare the value of avoiding environmental harms with the value of other public benefits lost in altering the project. This balancing of values would determine if the alterations are feasible. However, as indicated above, ${ }^{226}$ such a cost-benefit rule may not be very reliable or very informative so long as the analysis inust reduce disparate values to a single monetary measure.

Another rule has therefore been suggested: an alternative is not imfeasible if it only requires a "reasonable" percentage of additional public costs. ${ }^{227} \mathrm{~A}$ reduction in public benefits is an additional public cost that could be evaluated under this rule. ${ }^{228}$ Thus, for exanple, a court could reverse an agency that based its finding of infeasibility on the fact that the alternative would reduce the number of lousing units to be constrncted by only four percent. The court would hold that as a matter of law such a small reduction in public benefits does not render an alternative infeasible.

221. See text accompanying notes $232-41,274-96$ infra.

222. Courts might apply the substantial evidence test to review agency findings of unprofitability. The combination of a non-deferential rule of law (the profitability standard) with a deferential standard of review should at least result in reversal im cases where the agency's balancing is extremely difficult to justify.

223. In the case of a publicly constructed project, a claim of public infeasibility might be based on an increase in construction costs. A profitability standard would be no more helpful in reviewing that claim than in reviewing a loss of public benefits claim.

224. Where a private project is imtended to fulfill a public goal, an alternative project may be incapable of achieving that goal if the alternative is so unprofitable that no developer is likely to undertake it. See notes 199-200 and accompanying text supra. In that case the profitability standard is relevant to a claim of public infeasibility.

225. Note, The Least Adverse Allernative, supra note 6, at $752-53$ \& n.98.

226. See notes 218-21 and accompanying text supra.

227. See Note, The Least Adverse Aliernative, supra note 6, at 753-54.

228. See id. at 751,754 . 
However, in order to apply this rule, the courts would have to fix the percentage of increase in public costs that would render a project infeasible. Some courts might be reluctant to apply this rule as a matter of law. ${ }^{229}$ Courts might consider any fixed percentage to be an arbitrary figure. In contrast, the profitability standard is related to the prevailing rate of return earned by actual investors. Yet without an objective standard to apply as a inatter of law, courts would review claims of public infeasibility under the substantial evidence test. Under that test, if an agency decided that a diminution in public benefits rendered a unodified project unsuccessful, a court might generally have to sustain the agency decision as not unreasonable, even though the court believed that a higher cost would be a reasonable price for environmental improveinents in the project. ${ }^{230}$ However, even under the substantial evidence test a court could reverse as unreasonable an agency decision that a very sinall shortfall in fully achieving some public goal rendered a modified project infeasible. ${ }^{231}$

\section{Review of the Reasonableness of the Balance Struck by the Agency}

The two "inatter of law" techniques discussed above would prevent an agency from insisting that a modified project must completely fulfill each of the proposed project's quantitative goals. These techniques, however, would not prevent an agency from approving a project that would cause serious environmental damage in order to meet some relatively unimportant social or economic goal. Matter of law techniques for reviewing the agency's balancing of environmental against social and economic factors are considered next.

CEQA provides that agency decisions can be set aside for abuse of

229. For a discussion of why courts employing the matter of law approach may prefer rules that look like "rules of law," see note 293 infra. Rather than applymg a rule of law, it might be easier for courts to employ an independent judgment standard to determine, on a case-by-case basis, how much of a loss of public benefits renders an alteruative infeasible. See notes 289-93 and accompanying text infra.

Difficulties might occasionally arise in applying a rule that an alternative is feasible so long as the resultimg shortfall in pnblic benefits does not exceed " $Y$ " percent. For example, where the agency has already reduced the scope of the project, the shortfall might be computed either by comparing the alternative with the project originally proposed or by comparmg it with the project as approved by the agency.

230. See note 56 and accompanying text supra.

231. The reasonableness of the agency decision might also depend upon the severity of environmental harin threatened.

Much greater changes in the scope of projects might be tolerated under a profitability standard. Therefore, plaintiffs seeking major alterations in projects might prefer to litigate the issue of private infeasibility. Compare Laurel Hills v. City Council (discussed in note 122 supra) with Burger v. County of Mendocino, 45 Cal. App. 3d 322, 119 Cal. Rptr. 568 (1st Dist. 1975) (discussed im note 200 supra), cases in which plamtifis claimed that alternatives were not unprofitable. 
discretion; e.g., for failure to act as required by law. ${ }^{232}$ Although CEQA allows environmentally damaging projects to be approved when there are countervailing economic or social considerations, ${ }^{233}$ that cannot mean that any economic or social consideration is sufficient to outweigh every environmental harm. If it could, the duty to approve feasibIe, environmentally superior alternatives or mitigation measures could be so easily avoided that it would be virtually meaningless. Therefore, CEQA must, as a matter of law, prohibit agencies from balancing these considerations im an unreasonable manner. CEQA indicates that feasibility is to be determined by taking into account environmental as well as economic, social and technological factors. ${ }^{234}$ Thus courts could find, as a inatter of law, that projects causing unreasonable environmental harm are infeasible, i.e., unsuccessful. Consequently, an agency that imvents a goal for the purpose of proving modified projects infeasible should be reversed for abusing its discretion. More importantly, when an agency approves a project causing serious environmental harm in order to achieve a comparatively unimportant economic or social goal, the courts should reverse for abuse of discretion.

Consider the case of an agency that has approved a sprawling hillside subdivision imstead of an alternative because that alternative would provide housing that is shightly less fashionable. An agency can justify approving a project imstead of an environinentally superior alternative only on the basis of those goals that would be met by the approved project but not by the alternative. ${ }^{235}$ The only goal not inet by the alternative would be the goal of being highly fashionable. Therefore, the agency could not attempt to justify approving the proposed project, instead of the alternative, on the basis of the need for housing. If the proposed project threatened serious environinental harm, while the alternative did not, the goal of being fashionable might well be so unimportant in comparison to the harm that a court could overturn the agency's approval as an abuse of discretion. By a similar process of analysis, courts might overturn other agency findings of infeasibility based on excessively narrow goals.

232. See CAL. PUB. Res. CODE $\$ \S 21168,21168.5$ (West 1977) (the former incorporating by reference CAL. Civ. Proc. CODE $\$ 1094.5(b)$ (West 1980)).

233. See Cal. Pub. Res. Code $\S \S 21002,21002.1$ (West 1977 \& Supp. 1980) quoted at note 32 supra.

234. Id. \& 21061.1 (West 1977).

235. In other words, when comparing the costs and benefits of two alternative projects, the marginal costs should be compared with the inarginal benefits. See Note, The Least Adverse Alternative, supra note 6, at 752-53. Although it may be inappropriate to atteinpt to compare costs and benefits by reducing them to a single monetary scale, they can still be compared in an inpressionistic way. 
Overly localized goals may be particularly vulnerable to attack as unreasonable. In Associated Home Builders v. City of Livermore, the California Supreme Court noted that "an ordmance, superficially reasonable fron the limited viewpoint of the municipality, may be disclosed as unreasonable when viewed from a larger perspective."236 Because the inunicipality's police power is derived from the state's power to advance the public welfare, according to the court an ordinance that significantly affects the welfare of people residing outside of the municipality must bear a reasonable relationship to the regional welfare. ${ }^{237}$ The California Supreme Court laid down this rule to guide trial court review of zoning ordinances that limit development. The Supreme Court of Washington, however, has apphed this "duty to serve the regional welfare" to local agency approvals of development projects. ${ }^{238}$ Quoting extensively froin Associated Home Builders, the court in Save a Valuable Environment v. City of Bothell overturned the city's approval of a major shopping center because the city had failed to mitigate or avoid potentially serious adverse environmental effects on areas outside of the city. The court held that a duty to consider and serve the regional welfare should be enforced when local agencies, im order to obtam local benefits, approve projects that have serious regional impacts. ${ }^{239}$ Thus, a municipahty that approved a sprawling development pattern in order to preserve the "character of the community" could be required to mitigate the serious air pollution that such a pattern of developinent would impose on surrounding communities. ${ }^{240}$ Similarly, a municipality that approved the destruction of a unique natural habitat in order to increase local tax revenues could be reversed for failure to reasonably balance regional and local interests. ${ }^{241}$

236. Associated Home Builders, Inc. v. City of Livermore, 18 Cal. 3d 582, 607, 557 P.2d 473, 487, 135 Cal. Rptr. 41, 55 (1976).

237. Id. at $607-09,557$ P.2d at 487-89, 135 Cal. Rptr. at 55-57. Associated Home Builders defines the relevant region as "the region significantly affected by the ordinance." Id. at 607 \& n.24, 557 P.2d at $487-88$ \& n.24, 135 Cal. Rptr. at 55 \& n.24.

238. Save a Valuable Environment (SAVE) v. City of Bothell, 89 Wash. 2d 862, 871, 576 P.2d 401, 406 (1978).

239. Id. at 871-72, 576 P.2d at $406-07$.

240. See text accompanying notes 145-50 supra for a discussion of Livermore's failure to adopt certain mitigation measures proposed to deal with the air pollution resulting from a sprawling developinent pattern.

241. See text following note 112 supra for a discussion of the natural habitat-tax revenue conflict.

Associated Home Builders clearly contemplated reversal of agency decisions for unreasonable balancing. "[The court inust] determine whether the ordinance, in hight of its probable impact, represents a reasonable accommodation of the competing imterests." $18 \mathrm{Cal} .3 \mathrm{~d}$ at $609,557 \mathrm{P.2d}$ at 488, $135 \mathrm{Cal}$. Rptr. at 56. However, it is not clear jnst what affirmative duties Associated Home Builders imposes on municipalities. The court cited as an example of a reasonable accommodation a case in which the competing interests balanced by the local agency were both regional in 
While it is possible for courts to set aside, as a matter of law, an agency's approval of a project because the balance struck by the agency is unreasonable, courts ordinarily will be reluctant to reverse on that ground. As discussed above, courts tend to review mixed questions of law and fact, such as findings of infeasibility, by the deferential substantial evidence standard. ${ }^{242}$ When the federal courts have applied the similarly deferential "arbitrary and capricious" standard ${ }^{243}$ in substantively reviewing environmental trade-offs under the National Environmental Policy Act, ${ }^{244}$ they have upheld agency decisions. ${ }^{245}$ At least

nature. $I d$ at n.26. This example suggests that the municipality is required to serve regional goals in some positive way. This conclusion is further supported by the court's approval of the following language from South Burlington County N.A.A.C.P. v. Township of Mt. Laurel, 67 N.J. 151, 177, 336 A.2d 713, 726 (1975): "the welfare of the state's citizens beyond the borders of the particular municipality cannot be disregarded and must be recognized and served." Quoted at 18 Cal. 3d 608, 557 P.2d 488, 135 Cal. Rptr. 56 (emphasis added by this author). However, the most frequently repeated version of the requirement imposed by Associated Home Builders is much less informative: the act of the local goverment must "reasonably relate" to the regional welfare. See I8 Cal. 3d at 607, 609-10, 557 P.2d at 488-89, 135 Cal. Rptr. at 56-57. SAVE v. City of Bothell more clearly establishes the affirmative duty to serve the regional welfare by mitigating adverse regional effects. 89 Wash. 2 d at $871-72,576$ P.2d at 406-07.

242. See note 193 and text accompanying notes 54-55, 188, supra. For example, the court in Foundation for San Francisco's Architectural Heritage v. San Francisco (City of Paris), 106 Cal. App. 3d 893, 165 Cal. Rptr. 401 (Ist Dist. 1980), hg. denied, Aug. 21, 1980, reviewed agency findings of infeasibility solely under the substantial evidence test.

An agency's lack of environmental expertise ought to encourage the court to review the agency's determmation of environmental issues as a matter of law, when that is possible, rather than under the more deferential substantial evidence test. See Sive, supra note 188, at 626-31. $C$. notes 285, 358-60 and açcompanying text infra (agencies' general lack of environmental expertise argues in favor of amending CEQA to substitute independent judgment standard of review for substantial evidence standard).

243. See S. Breyer \& R. Stewart, Administrative Law \& Regulatory Policy 288-90 (1979) (courts have been "extremely reluctant" to overturn agency decisions under the arbitrary and capricious standard).

244. National Enviommental Pohcy Act of 1969 [NEPA], 42 U.S.C. $\$ \S 4321-4369$ (1976 \& Supp. II 1978).

CEQA was modeled on NEPA. Comment, Aftermammoth, supra note 15, at 352; see Friends of Mammoth v. Board of Supervisors, 8 Cal. 3d 247, 260-61, 502 P.2d 1049, 1057-58, 104 Cal. Rptr. 761, 769-70 (1972). The 1976 amendments, however, were not derived from NEPA. NEPA does not explicitly mandate that agencies disapprove projects when there are feasible, environmentally superior alternatives. See Note, CEQA's Substantive Mandate Clouded, supra note 15, at 10208.

245. See Note, The Least Adverse Alternative, supra note 6, at 746; see, e.g., Jackson County v. Jones, 57I F.2d 1004, 1015 (8th Cir. 1978) (court upheld agency's decision even though the court seemed convinced that the agency had approved a project whose detriments outweighed its benefits); Environmental Defense Fund, Inc. v. Corps of Engineers, 470 F.2d 289 (8th Cir. 1972), cert. denied, 412 U.S. 931 (1973).

The standard for substantive review of agency decisions under NEPA was set out in Calver Cliffs Coordinating Comm., Inc. v. United States Atomic Energy Comm'n, 449 F.2d 1109, 1115 (D.C. Cir. 1971): "The reviewing courts probably cannot reverse a substantive decision on its nerits . . . unless it be shown that the actual balance of costs and benefits that was struck was arbitrary or clearly gave insufficient weight to environmental values."

In Strycker's Bay Neighborhood Council, Inc. v. Karlen, 444 U.S. 223, 227 (1980) (rev'g, per 
one California court has affirmed an agency decision, noting that although CEQA "requires decision makers to assign greater priorities to environmental values than to economic needs . . . [t]hat is not to say that the courts will substitute their judgment for that of the responsible agency."246 Associated Home Builders also suggests that the California courts will apply a fairly deferential standard in reviewing local accommodation of regional imterests. ${ }^{247}$

curiam, Karlen v. Harris, 590 F.2d 39 (2d Cir. 1978)), the Supreme Court, quoting from Vermont Yankee Nuclear Power Corp. v. NRDC, 435 U.S. 519, 558 (1978), reiterated that "NEPA, while establishing 'significant substantive goals for the Nation,' imposes upon agencies duties that are 'essentially procedural.'" Strycker's Bay therefore allowed the agency to proceed with the proposed project. A footnote left open the possibihty of substantive review of agency decisions under the arbitrary and capricious standard. But the Court noted that NEPA provides no support for "a reordering of priorities by a reviewing court." 444 U.S. at 228 n.2.

Strycker's Bay overturned the Second Circuit's ruling that "delay [resulting from building an alternative project instead of the project originally proposed] is not to be regarded as an overriding factor and that environmental factors . . . should be given determmative weight." Karlen v. Harris, 590 F.2d at 44. Strycker's Bay apparently seeks to limit the lower courts' ability to employ the matter of law approach as a means of substantively reviewing agency decisions under NEPA, much as Vermont Yankee sought to limit quasi-substantive review.

Vermont Yankee limited the courts' ability to impose procedural requirements stricter than those exphicitly mandated by statute. The Supreme Court disapproved using such requirements to encourage agencies to decide substantive issues the way the courts would like to see them decided. Sirycker's Bay similarly prohibits the courts from imposing substantive NEPA requireinents stricter than those explicitly mandated by statute.

Unlike NEPA, CEQA exphcitly imposes a substantive duty on agencies to disapprove projects when there is a feasible, environmentally superior alternative. Therefore, California courts should not be opposed to construmg the statute to include more particularized substantive requirements than those explicitly spelled out in the statute. Cf. Citizens to Preserve Overton Park, Inc. v. Volpe, 401 U.S. 402, 41 1-13 (1971), where the Court construed an explicitly substantive duty quite strictly. In Overton Park, the Court held that a statute prohibiting construction of lighways through parks "unless there is no feasible and prudent alternative" (Section 4(f) of the Department of Transportation Act of 1966, as amended, 49 U.S.C. $\$ 1653(\mathrm{f})(1976)$ ) prevented the approval of parkland routes unless "alteruative routes present unique problens." 401 U.S. at 413. On the other land, if the California courts were to adopt the approach taken by the Supreme Court in Strycker's Bay, they would effectively limit substantive review to application of the deferential substantial evidence test by precluding use of the more intrusive matter of law techniques.

246. San Francisco Ecology Center v. City and County of San Francisco, 48 Cal. App. 3d 584, 591,122 Cal. Rptr. 100, 104 (1975) (emphasis added) (decided prior to passage of the amendments discussed in this Comment).

However, at some point the court must substitute its judgment for that of the agency, im deciding whether particular economic needs are important encugh to warrant serious environmental degradation. Otherwise the decisionmaker's CEQA duty would be unenforceable and illusory. See text accompanying notes 232-34 supra. See also text accompanying notes 60-63 supra.

247. See, e.g., $18 \mathrm{Cal}$. 3d at 603, 606, $557 \mathrm{P} .2 \mathrm{~d}$ at $485,486-87,135 \mathrm{Cal}$. Rptr. at 53, 54-55. The court noted that a zoning ordmance normally, although not always, will be upheld where it is " 'fairly debatable' that the ordinance reasonably related to the regional welfare." Id. at 609,557 P.2d at 488-89, 135 Cal. Rptr. at 56-57 (citation omitted). Associated Home Builders also approves a number of apparently less deferential standards:

We do not hold that a court in inquiring whether an ordmance reasonably relates to the regional welfare, cannot defer to the judgment of the municipahty's legislative body. But judicial deference is not judicial abdication. The ordmance must have a real and substan- 


\section{Judicial Reluctance to Review Findings of Infeasibility as a Matter of Law}

Courts generally may be reluctant to review findings of infeasibility as a matter of law. CEQA does not specify any standards by which to judge the agency's decision that an alternative is infeasible. ${ }^{248}$ In order for the CEQA amendments to be given their proper substantive effect, the courts must craft standards ${ }^{249}$ or decide issues as a matter of law on a case-by-case basis. ${ }^{250}$

Lack of standards might be particularly troublesome if the courts were to review the reasonableness of the balance struck by the agency as a matter of law. A rule requiring reasonable balancing by the agency does not tell a court how to decide any particular case. In contrast, both the profitability standard and the reasonable percentage of additional costs rule, if endorsed by the appellate courts, would give trial courts objective, readily applicable standards for deciding numerous cases. In order to fashion a generalizable rule of law, then, courts are likely to reduce "reasonableness" to a formula. The formula selected, such as "arbitrary and capricious," is likely to require a minimal standard of reasonableness. ${ }^{251}$ It is probably impossible to articulate a formula that is more stringent than reversal only for total unreasonableness. ${ }^{252}$ If the courts use the arbitrary and capricious formula to

tial relation to the public welfare. There must be a reasonable basis in fact, not in fancy to support the legislative determination.

Id. at 609,557 P.2d at 488-89, 135 Cal. Rptr. at 56-57 (citations and footnote omitted).

Associated Home Builders challenged the local ordmance on constitutional grounds. A CEQA challenge is based on statutory grounds. Because statutes are more easily amended than the constitution, courts may not be so reluctant to overturn local decisions in CEQA cases.

248. See text accoinpanying notes 38-44 supra. For the statutory definition of "feasible," see CAL. Pub. Res. CODE $\$ 21061.1$ (West 1977) and text accompanying note 38 supra.

249. See text accompanying notes 196-231 supra for the standards which this Comment has suggested are appropriate for the courts to adopt.

250. If courts were to review the reasonableness of agency decisions as a matter of law, they could examine all the circumstances of each case. Such a "totality of the circumstances" approach would result in case-by-case review.

251. "Arbitrary and capricious" is a formula applied to judicial review of administrative agencies under the federal Administrative Procedure Act, 5 U.S.C. $\$ 706(2)(A)$ (1977). This standard can be employed to test whether agency actions or conclusions of law are "according to law." Id. In practice, courts reverse under this standard only if there is "no rational basis whatsoever" for the agency's decision. Accordingly, few administrative actions have been reversed as arbitrary and capricious. S. BREYER \& R. STEWART, supra note 243 at $289 \&$ nn. $86,87$.

252. So long as the validity of the agency's reasoning is debatable, it is difficult to set down a rule of law that will clearly separate valid from invalid reasoning. On the other hand, courts seem to think that once doubts are dispelled a clear rule appears. Questions that would ordinarily be considered questions of fact suddenly are treated as questions of law when the court beheves that "reasonable minds could not differ."

Since it is the courts' task to define the law, when the courts asserted the power to decide questions on which "reasonable minds could not differ," these issues were labeled as questions of law. The courts assumed this power in order to control juries, to prevent them from going com- 
judge reasonableness as a matter of law, then the result will be essentially the same as applying the substantial evidence test. ${ }^{253}$ Hence, courts are unlikely to embark on wide-ranging, case-by-case mquiry into the reasonableness of an agency's balancing under the inatter of law approach, ${ }^{254}$ and in fact may contmue to defer to agency judgment.

Perhaps courts would be more willing to decide issues as a matter of law on a case-by-case basis or craft standards, such as a profitability standard, if the language of CEQA were inore emphatic. When the 1976 amendinents were first being considered it was proposed that an alternative could be found infeasible only because of "compelling economic, social, or other conditions."255 If that language had been adopted, courts might be less reluctant to overturn dubious agency decisions, such as an approval based on the need to imcrease consumer purchasing power in an already affuent neighborhood. ${ }^{256}$ On the other

pletely astray. However, a rule allocating power between judges and juries is not necessarily relevant to the allocation of power between courts and agencies. The law that juries apply in the cases before them is designed to control the litigants, not the jurors. In contrast, CEQA is intended to control agencies that are applying the law to their own actions, i.e., their approval of projects. It seems inappropriate to take a rule that expands the power of courts, by allowing judges rather than juries to decide questions about which reasonable minds could not differ, and convert it into a limit on the courts' power to tell agencies whlat the law is. This arguinent would also suggest that the substantial evidence test should not be construed as a limit on the courts' power to decide issues as a matter of law. Cf. discussion of Strycker's Bay, note 245 supra (arbitrary and capricious test is the limit of the courts' power to say what the agency's duty is under NEPA).

253. See K. DAvis, supra note 55, at 536-37 (3d ed. 1972); note 243 supra. See also note 245 and accompanying text supra (deferential apphication of arbitrary and capricious standard under NEPA).

As has been discussed above, the substantial evidence standard is highly deferential when a court is reviewing an agency's balancing of competing values. See uotes 54-56, 97-102 supra. Prior to balancing values, the agency considers factual inatters which indicate to what degree particular values are at stake. Thus, if the agency has failed to consider an essential factor, a reinand for reconsideration is likely even under the substantial evidence standard. However, such a reinand, like a procedural remand, geuerally leaves the agency free to arrive at the same result after consideration of the proper factors.

254. See note 293 infra.

255. See Meinorandum to Claire T. Dedrick from Norman E. Hill of the California Resources Agcncy regarding April I9, 1976 Assembly Amendments to A.B. 2679, at 2 (April 29, 1976) (on file with the California Law Review).

CAL. Pub. Res. Code $\$ 21001$ (d) (West Supp. 1980) does establish a state pohicy of ensuring "that the long-term protection of the environment, consistent with the provision of a decent hoine and suitable living environment for every Californian, shall be the guiding criterion in public decisions." The "the guiding criterion" language was part of CEQA when the court in San Francisco Ecology Center v. City and County of San Francisco, 48 Cal. App. 3d 584, 122 Cal. Rptr. 100 (1975), adopted a deferential stance in reviewing the city's balancing of competing considerations. See text accompanying note 26 supra. Thus, it is not clear how inuch more carefully the courts would be scrutinizing agency decisions if the "compelling conditions" language had been enacted.

256. Cf. discussion of the Laurel Hills case at text accompanying note 107 supra (goal of increasing "local consumer purchasing power by nearly $\$ 3$ million per year" in upper income area in the Santa Morica Mountains).

Cf. text of the statute as enacted: An alternative is infeasible if it is "[in]capable of being 
hand, such language might inerely have resulted in judicial deference to agency determinations of what is a compelling consideration. ${ }^{257}$

Courts that are reluctant to decide issues as a inatter of law may prefer to decide questions under the substantial evidence test. ${ }^{258}$ Courts may avoid deciding issues as a matter of law and prefer the substantial evidence test because they beheve that courts ought to defer to the policy judgments of politically responsive expert agencies. ${ }^{259}$ However, this Comment will argue that agencies making determinations of infeasibility under CEQA are not expert in the field of environmental protection and, especially in the case of local agencies, may not be responsive to the statewide pro-environmental policies of CEQA. ${ }^{260}$ Nevertheless, courts may still adhere to this tradition of deference.

Even if the courts do apply the matter of law approach, they may apply it im a deferential manner. The substantial evidence test requires a considerable degree of deference to the agency. And while the matter of law approach permits a greater degree of scrutiny than the substantial evidence test, it neither requires nor prohibits deferential review. Tlus, for example, even if the appellate courts were to proinulgate the profitability standard as a rule of law, trial courts inight review agency findings that a particular project was indeed unprofitable with a great deal of deference. ${ }^{261}$ Therefore, it may be necessary to amend the Act

accomplished in a successful manner within a reasonable period of time, taking into account econoinic, environmental, social and technological factors." CAL. PUB. Res. CODE $§ 21061.1$ (West 1977).

257. Judicial reluctance to craft standards or decide issues on a case-by-case basis might be overcoune by annending CEQA to provide for imdependent judgment review of agency decisions. The independent judgment approach would invite the courts to evolve standards or engage in case-by-case determinations, an invitation not extended explicitly by the statute as it now reads. See notes 262-64 and accoinpanying text infra.

258. As noted above, the agency's finding of infeasibility presents the court with a mixed question, and courts tend to decide inixed questions under the deferential substantial evidence test. See notes 49-56 supra and accounpanying text.

259. See K. DAvis, supra note 55 , at 553.

260. Davis notes that the degree of judicial deference accorded agencies may also depend on the courts' confidence in the agency's decisionmaking ability and the nature of the decision beimg made by the agency. K. DAvis, supra note 55, at 552-53. Zoning and land use decisions have traditionally been accorded deference in California. See Associated Homebuilders v. City of Livermore, 18 Cal. 3d at 604-05, 557 P.2d at 485-86, 135 Cal. Rptr. at 53-54. However, this deferential attitude does not take account of the limitations that CEQA places on agencies. Furtherinore, local agencies unay be insensitive to environmental impacts, particularly where most of the adverse effects are felt outside of their jurisdiction. Similarly, special-purpose state agencies may be biased by their development-oriented missions. Thus, courts may have reason to distrust the ability of agencies to properly consider environmental factors.

261. See notes 194, 222 supra. Cf. notes 54-56 supra and accompanying text (courts may apply the substantial evidence test to agency findings of infeasibility). Cf. Foundation for San Francisco's Architectural Heritage v. San Francisco (City of Paris), 106 Cal. App. 3d 893, 904, 917, 165 Cal. Rptr. 401, 407, 415 (1st Dist. 1980), hg. denied, Aug. 21, 1980 (court construed agency findings that an alternative would be substantially more costly and fail to meet the developer's 
in order to discourage overly deferential review and ensure adequate substantive enforcement of CEQA.

IV

\section{The INDEPENDENT Judgment Standard OF Review: A Proposed AMENDMENT AND ITS AdVANTAGES OF FLEXIBILITY AND CANDOR}

This Comment proposes amending CEQA to instruct the courts to use their independent judgment, as opposed to the substantial evidence test, in reviewing agency findings of infeasibility. This proposal would not extend the imdependent judgment standard of review to other agency findings made under CEQA. Where an agency disapproves a project because there is a feasible alternative, the agency's action should not be reviewed under the independent judgment standard. ${ }^{262}$

The proposed ainendinent would allow courts to substantively review agency decisions more readily than under the existing law. The agency's definition of a project's goals would not bind the courts. An

marketing requirements to mean that "the economics of [the alternative] precluded any reasonable, economic use of the property by the owner").

Just as courts may apply the profitability standard in a deferential manner, they might set a very low percentage under the additional public costs rule, establisling a relatively easy standard for findings of infeasibihty.

See also the discussion of the deferential application of the reasonableness as a matter of law approach, notes $242-54$ and accompanymg text supra.

262. CEQA applies to projects whose approval is discretionary with the agency (CAL. PuB. RES. CODE $\S \S 21002.1$ (c), 21080(a) (West Supp. 1980)). Even if the alternative were in fact infeasible, the agency would still lrave the discretionary power to disapprove the project for other reasons.

Nor does this Comment propose to extend the independent judgment standard of review to findings as to the environmental consequences of projects and alternatives. However, retention of the substantial evidence standard of review for agency findings of fact might encourage agencies to slant EIR's and make them less objective documents. Agencies might be tempted to describe substantial impacts as insignificant, or to make the proposed project appear environmentally superior. Cf. Hildreth, Environmental Impact Reports under the California Environment Quality Act: The New Legal Framework, 17 S. Clara L. Rev. 805, 819 (1977) (the effect of the 1976 amendments may be to tempt those responsible for the preparation of the EIR's to label as insignificant many impacts formerly designated as significant). This already lrappens to some degree. In the Laurel Hills case, for example, the city found that grading 1.6 million cubic yards of eartl on steep hillsides would have no significant adverse effect. See Laurel Hills Homeowners Ass'n v. City Council, No. C 193823 at 6, 11 (Super. Ct., Los Angeles County, Nov. 3, 1977), aff'd on other grounds, 83 Cal. App. 3d 5I5, 527, I47 Cal. Rptr. 842, 849 (Aug. I978). When Hayward rezoned the Soda property, one of the claimed advantages of the project was the dedication of thirty acres of permanent open space. This was supposed to make the project environmentally attractive, even though the whole of the site was in open space and under study for permanent preservation, although only guaranteed to remaim im open space for another ten years. See STATEMENT of OverRIDING CONSIDERATIONS, attached to Notice of Determination, regarding City of Hayward Agricultural Preserve No. 1 (filed by City of Hayward witl Alameda County Clerk Jan. 19, 1979); Statement of OVERriding Considerations, attached to Hayward Zone Cliange Notice of Determination, supra note 151; Lewis \& DeBonis, supra note 151, at 2; text accompanymg notes 151 52 supra.) 
independent judgment standard of review would invite the courts to review the substance of agency decisions by independently judging the feasibility of the alternatives. Existing law unfortunately may encourage courts to defer totally to an agency's selection and balancing of goals. ${ }^{263}$ Yet the agency's decision that the failure to achieve particular goals makes alternatives infeasible may be the crucial factor that underlies the agency's final decision to approve a project. ${ }^{264}$ The independent judgment standard of review would enable courts to review these choices. The independent judginent standard offers soine promise of effective enforcement of the substantive duty imposed on agencies by the 1976 amendinents to disapprove projects when a feasible, environmentally superior alternative exists.

As detailed above, under existing law courts might review agency findings of infeasibility by applying the substantial evidence test, ${ }^{265}$ or by reviewing these findings procedurally, ${ }^{266}$ quasi-substantively, ${ }^{267}$ or as a matter of law. ${ }^{268}$ However, these approaches may not result in much effective enforcement of the substantive duty announced by the 1976 CEQA amendments. The substantial evidence approach is likely to be inadequate because it is too deferential. ${ }^{269}$ Procedural review encourages but does not require the agency to make the right decision; ${ }^{270}$ unsympathetic agencies may disregard this encouragement. Moreover, a genuinely procedural approach may result in reinands where there is no underlying substantive problem. ${ }^{271}$ And, for reasons discussed below, ${ }^{272}$ courts inay be reluctant to use procedural remands quasi-substantively. The matter of law approach, as suggested above, ${ }^{273}$ is likely to be applied, if at all, in a highly deferential manner. In contrast, the independent judgment standard imvites the court to actually review the substance of the agency's decision.

Under existing law, the agency, in determining whether or not an alternative is feasible, should consider the seriousness of the environmental harm avoided by the alternative, as well as the costs of avoiding that harm, i.e., additional economic costs or lost benefits. ${ }^{274}$ Under the

263. See text accompanying notes 49-57 supra.

264. See text accompanying notes $45-46$ supra.

265. See text accompanying notes 49-57 supra.

266. See text accompanying notes 126-66 supra.

267. See text accoinpanying notes 167-87 supra.

268. See text accompanying notes 188-261 supra.

269. See text accompanying notes 49-57, 97-102 supra.

270. See text accompanying notes 60-63, 164-66 supra:

271. See text accompanying notes 284-85 infra.

272. See text accompanying notes 281-85 infra.

273. See text accompanying notes 242-61 supra.

274. " 'Feasible' means . . . successful . . . taking into account economic, environmental, social and technological factors." CAL. PUB. REs. CODE $\$ 21061.1$ (West 1977). 
independent judgment standard, the courts would have the power to weigh the seriousness of the environmental harm avoided by an alternative in reviewing an agency's finding that an alternative is infeasible. ${ }^{275}$ The independent judgment approach, then, is more flexible than existing law because it allows the court to weigh the facts of each case. A court employing the independent judgment standard could, for exainple, discount overly particularized goals in the face of serious environmental harm. ${ }^{276}$ Similarly, a court employing the independent judgment standard might find the agency's chosen goals comparatively unimportant, considering the environmental threat. 277 Thus, the independent judgment standard should reach substantive problems that are difficult to approach by other review techniques. In contrast, procedural review, quasi-substantive review, and the matter of law approach may require a court to establish standards that ostensibly apply to all cases. Courts employing the independent judgment approach, on the other hand, sliould reverse if and only if the threatened harm is more serious tlian the added costs.

The independent judgment standard, however, would not abrogate the procedural requirements set out in the Act and the Guidelines, nor those judicially recognized procedural requirements that are necessarily miplied by the Act. The statutory procedural requirements encourage agency consideration of all the relevant factors; findings requirements also inandate disclosure of agency reasoning to public scrutiny. ${ }^{278}$ Because the imdependent judgenent approach provides for explicitly substantive review of agency decisions, ${ }^{279}$ courts would employ procedural review only for procedural purposes. The independent judgment standard would make quasi-substantive review unnecessary. Courts would not have to invent ever-stricter procedural requirements in order to reverse substantively imcorrect decisions. ${ }^{280}$

275. An alternative that avoids more environmental harm may be "feasible" since it is more "successful" than one that causes more harm. See id.

276. Thus, if serious harm were threatened, a court einploying the independent judgment standard might find that a residential subdivision was feasible so long as it provided housing, regardless of whether it fulfilled a "demand" for spacious, gracious, sprawling hillside homes. Similarly, an activist court might discount a goal of providing housing locally when the need for housing could be met elsewhere in the region. $C$. note 112 and accompanying text supra (proper to discount local goals).

277. For example, a court might find that maintaining the character of a commumity (its suburban aura) did not justify the increase in air pollution that it would cause.

278. See notes $21-22,37,126$ and accompanying text supra.

279. The Act already imposes a substantive duty on the agencies. However, the present standard of review may deter substantive enforcement of that duty. Therefore, replacing the present standard of review with a more probing standard should allow for greater substantive enforcement of the statutory mandate.

280. This form of quasi-substantive review was disapproved of in Vermont Yankee Nuclear Power Corp. v. NRDC, 435 U.S. 519 (1978). 


\section{A. The Independent Judgment Standard and Quasi-Substantive Review Compared}

While quasi-substantive review ${ }^{281}$ implicitly considers the particular circumstances of the case, it does not explicitly address the factors that are actually motivatimg the court to remand. Thus, the procedural rule laid down to effect the remand typically does not refer to the seriousness of the environmental larm threatened, the likelihood that the agency will make sigmificant clianges in the project on remand, or the costs of altering and delaying the project. ${ }^{282}$ Instead, the court pronounces a rule, which on its face, apphes to all cases regardless of the seriousness of the environmental harm. ${ }^{283}$ Thus, a court might be wary of laying down a procedural rule in order to correct a substantive error. Even though the court is convinced that the environmental harm threatened by the project under review is serious enough to warrant a remand, it might be fearful that other courts will woodenly apply the procedural rule to projects not threatening such serious harm or to decisions that are not substantively erroneous, though procedurally improper. ${ }^{284} \mathrm{~A}$ similar dilemma is faced by a court that is asked to apply a procedural rule that has a quasi-substantive origim to a case involving much less serious environmental harm than the case in which the rule originated. The court must either ignore a rule that ostensibly applies to the case, or else order a remand that it feels is not justified on the facts. Unfortunately, a court that chooses to ignore such a requirement because it would produce an inappropriate result im a particular case may write an opinion apparently indicating that the rule need never be

281. See notes 167-87 and accoinpanying text supra.

282. Some of this cost may result from further delay in constructing the project due to the remand. High interest rates have greatly increased the econounic costs of delay. Pcrhaps courts ought to ignore the cost of remand-induced delays, however, because these delays are the result of the agency's failure to make the proper decision in the first place. See notes 297-98 and accompanying text supra.

283. Of course, the environmental impact report and the agency's findings generally need not deal with "insignificant" effects. Thus, a rule requiring a procedural remand typically would not apply to projects threatening only trivial impacts. Nevertheless, once the minimal, threshold level of "significance" is passed, procedural rules do not take account of how serious an environmental threat a project poses, nor of the costs of remanding.

284. $C f$. the discussion of how thorough an explanation of an agency's decision the courts are hikely to require at text accompanying notes $139-66,175-82$ supra. The less reasonable a decision seems, the more explanation a court is likely to want. Nevertheless, it may hesitate to set down a rule requiring an exceptionally thorough explanation if the rule is likely to be applied to less egregious cases as well. A rule requiring especially thorough explanations across the board might result in either unnecessary paperwork or im the reversal of numerous agency decisions, including some that were substantively pernissible.

Because the quasi-substantive approach explicitly refers only to procedural requirements that are then enforced selectively, agencies may be unclear as to just what is required of them. Agencies that attempt to follow case law to the letter might, for example, study more alternatives than is really necessary or helpful. Other agencies might be tempted to totally ignore these requirements. 
comphed with. ${ }^{285}$

In contrast, the independent judgment standard would allow a court to address explicitly, on a case-by-case basis, the factors that actually motivate quasi-substantive decisions. Courts using the imdependent judgment standard would not purport to be setting down rules that apply to cases with dissimilar substantive facts. Thus, courts authorized to use their independent judgment should not have to worry about other courts repudiating rules in cases with unsympathetic facts or applymg rules in inappropriate cases, two dangers inherent in quasisubstantive review. ${ }^{286}$

Because the imdependent judgment standard encourages the court to consider exphcitly the factors actually underlying a quasi-substantive decision, it has the further advantage of being a inore candid and straightforward approach than quasi-substantive review. In addition, the independent judgment approach has the advantage of exphicitly informing the agency of what it did wrong. ${ }^{287}$ Perhaps most importantly, because it is explicitly substantive, the independent judgment approach has the advantage of preventing the agency from proceeding with the project until it alleviates the environmental harm threatened by the project. $^{288}$

\section{B. The Independent Judgment Standard and Matter of Law Approach Compared}

The independent judgment approach is also more flexible than a

285. This problem is especially serious where the procedural requirement is imposed by CEQA or the Guidelines, rather than merely by case law. See text accompanying notes 278-79 supra.

Cf. Big Rock Mesas Property Owners Ass'n v. Board of Supervisors, 73 Cal. App. 3d 218, 226-27, 139 Cal. Rptr. 445, 449-50 (1977), construmg 14 CAL. AdMIN. CodE § 15143(d) (May 10, 1980), which requires EIR's to “[d]escribe all reasonable alternatives to the project, or to the location of the project, which could feasibly attain the basic objectives of the project." The court construed the Guidelines to require only consideration of alternatives to the project as a whole and not consideration of alternatives to the most environmentally damaging aspects of the project-even though $\S 15143$ (d) requires "[t]he discussion of alternatives . . . capable of substantially reducing or eliminating any significant environmental effects." The court seems to have found that the EIR adequately discussed measures for mitigating the most environmentally damaging aspects of the project. Therefore, a holding that the particular ElR was adequate would have been inore appropriate. Instead, the court imphed that alternatives to less than all of a project never need be discussed. Such a general rule would not ensure adequate consideration of ineans of avoiding serious environmental impacts where relocation of a portion of the project could significantly reduce those impacts, and other mitigation measures could not.

286. Froin a substantive point of view any procedural rule is likely to be over- or underinclusive, regardless of whether it is applied quasi-substantively or for purely procedural reasons.

287. Cf. text accompanying note 164 supra; note 168 and accompanying text supra (procedural review and quasi-substantive review may implicitly inform the agency of its substantive errors).

288. See text accompanying notes 13-16, 63 supra. 
matter of law approach. While matter of law approaches can be explicitly substantive, they typically depend on generally applicable, objective, a priori rules. The profitability standard and the additional percentage of public costs rule, for example, are objective but relatively rigid matter of law approaches that disregard the balancing of factors underlying agency findings of infeasibility. ${ }^{289}$ The independent judginent approach, on the other hand, recognizes that a finding of infeasibility is a determination that protecting the environment is not worth the economic and social costs of providing that protection. ${ }^{290}$ It also recognizes the difficulty of crafting precise rules before considering the complex, interacting factors involved in reaching a particular decision.

The cost-benefit ratio, another matter of law approach, would balance the underlying values, but would do so in a rigid way. ${ }^{291}$ It would atteinpt to draw a clear line between permissible and impermissible balances. The independent judginent standard, unlike a cost-benefit ratio, allows the court to consider values that are difficult to reduce to monetary terms and to consider the fact that certain costs are not borne

289. The additional percentage of public costs rule, in particular, allows a relatively arbitrary amount of additional costs to be imposed on a project before it can be considered unsuccessful. Not only might it be difficult to set a percentage figure, but it inight also be difficult to decidc which project or alternative the additional costs can fairly be inposed on. If an agency has already imposed the fixed percentage of additional costs on a proposed project, should a court then impose additional costs on the modified project? and so on ad infinitum? On the other hand, if the additional percentage of costs can only be imposed on the project origimally proposed, won't project proponents present projects larger in scope than what they expect the agency will approve or what they really want? Thus, a subdivider might propose a fifty-unit subdivision, knowing that the local agency would only approve a forty-unit subdivision for the tract. So long as the agency reduces the scope of the project by the requisite percentage in order to protect the environment, thus reducing the public benefits provided, this rule might prohibit the court froin reducing the project further. In this way a project's proponent might gain approval of the project he originally intended to construct, while shielding the agency's approval froin court reversal. $C$. note 80 supra (similar tactic is encouraged by the Laurel Hills decision). The independent judgment standard would avoid both these difficulties by balancing the amount of harm to the environinent agamst the costs of avoiding that harm. See also Note, The Least Adverse Alternative, supra note 6, at 752-53.

Of course, a profitability standard could be one factor considered by an "independent judginent" court in determining the feasibility of alternatives. See text accompanying notes 298, 307 infra.

290. See notes 48, 274 supra.

Cf. Jordan, supra note 173 , at 718 (the agency's ultimate decision is whether the benefits of the project outweigh its disadvantages).

291. A cost-benefit rule looks like a rule of law. See note 293 infra.

In any case, CEQA does not require agencies to prepare cost-benefit analyses. See San Francisco Ecology Center v. City and County of San Francisco, 48 Cal. App. 3d 584, 595, 122 Cal. Rptr. 100, 107 (1st Dist. 1975); see also 14 CAL. ADMIN. Code § 15012(b) (May 10, 1980) ("[elconomic information may be mcluded in an EIR or may be presented in whatever forn the agency desires"); EIR content guidelines at 14 CAL. ADMIN. CODE §§ 15140-15151 (May 10, 1980). 
by those who benefit from the project. ${ }^{292}$ Thus, the independent judgment standard would allow the courts to balance the multitude of factors properly underlying an agency's finding of infeasibility. ${ }^{293}$ The independent judginent standard inevitably gives the court a great deal of discretion. ${ }^{294}$ However, this is necessary to secure substantive enforcement of the Act in a way that appropriately deals with varying factual circumstances. ${ }^{295}$ In the absence of independent judgment power, the court inust either apply nore rigid rules to secure substantive enforcement, or limit itself to reversing only the most outrageously unreasonable decisions. ${ }^{296}$

\section{Advantages and Disadvantages of the Independent Judgment Standard}

There is a danger that trial courts might exercise the discretion granted them under the imdependent judgment standard by refusing to

292. See notes 219-20 and accompanying text supra.

293. The flexibility available under the independent judgment approach is potentially available to courts reviewing the reasonableness of agency decisions as a matter of law. These courts could judge the reasonableness of the agency decision considering the totality of the circumstances of each particular case. However, this flexibility would not be reahized if courts only required the agency decisions to be minimally reasonable. See text accompanying notes 251-53 supra. One reason why courts may only be willing to impose the more deferential reasonableness requirement is that a flexible reasonableness standard may not look like a rule of law. In contrast, the costbeneflt ratio, profitability standard, and additional percentage of public costs rule do look like rules of law. A rule of law is expected to be a general rule for objectively deciding cases. A flexible reasonableness standard, on the other hand, does not tell the court how to decide cases so much as that it ought to review the agency decision. Therefore, courts may be reluctant to apply such a standard as a matter of law. See K. DAvis, supra note $55, \S 30.06$, at 555 (review as a matter of law is "more likely, where the court is asked to enunciate a general proposition than where the only question is an appraisal of unique circumstances or an application of a general proposition or standard to particular facts"). Cf. note 252 supra (rule might be to reverse only what is totally unreasonable). See generally, text accompanying notes 248-54, 261.

294. The imdependent judgment standard tells the court to use its own judgment and prohibits unquestioning reliance on the agency's reasoning. See West Mich. Envt'l Action Council, Inc. v. Natural Resources Comm'n, 405 Mich. 741, 763-64, 275 N.W.2d 538, 541 (1979). Thus, it is unlike the substantial evidence test, which tends to dictate results by telling the court to be highly deferential. The imdependent judgment standard dictates inquiry, but not results. This lack of guidance may make appellate court control over trial court decisioninaking more difficult, especially if the clearly erroneous standard applies to appellate court review of trial court decisions. Thus, the imdependent judgment standard may in effect permit the trial court to defer to the agency's determimation by agreeing with its reasoning. The practical effect of applying the independent judgment standard may be more to remove a limit on the power of the courts than to require a different degree of deference.

295. Thus, the imdependent judgment standard meets the criticism that strict enforcement of environmental statutes will result in the delay or abandoninent of important projects for trivial reasons. However, those who find virtually all environmental harn trivial in comparison with economic beneflts will, of course, not be placated. Furthermore, the old criticism is likely to be replaced by a new criticism, that the imdependent judgment standard gives too much power to the courts. See Part VI infra for a reply to that criticism.

296. See note 252 and accompanying text supra. 
protect the environment. For example, courts might too readily find alternatives infeasible due to the delay that would be caused by reversing the agency's decision. Project proponents might argue that the costs of altering projects, especially after design work has been completed, justify proceeding with environmentally damagmg projects. ${ }^{297}$ Appellate courts inight disallow this argument and control the trial courts' exercise of discretion by ruling, as a matter of law, that a court cannot consider the cost of delay occasioned by the agency's failure to make a correct decision in the first instance. ${ }^{298}$ The mdependent judgment approach does not preclude the use of rules of law. However, the suggested rule still suffers froin the mflexibility of the matter of law approach. It might, for example, prevent a court from affirming an agency's good-faith project approval where relatively minor environinental improvements do not merit costly delays. The problem with the inatter of law approach is the difficulty of enunciating rules that clearly distinguish cases where a remand would be worthwhile from those where it would not be. ${ }^{299}$

Under the independent judgment approach courts might also perinit agencies to give too inuch weight to the costs imposed on private parties, since the profitability standard would no longer by itself determine the amount of such costs that could be imposed. Consider, however, that costs imposed on a developer may ultimately be paid by consumers. The profitability standard does not take account of that fact, ${ }^{300}$ but only asks if the developer can recover enough of his added costs to make a profit. The independent judgment approach trusts the court to properly weigh the detriment suffered by both consumers and investors as a result of added costs. Even if that trust is occasionally

297. Agencies might even knowingly approve a project instead of a feasible, environmentally superior alternative, hoping that if the project were later challenged, courts would be reluctant to reverse due to the costs of delay. The independent judgment standard should encourage courts to see through such a ploy.

298. Cf. Karlen v. Harris, 590 F.2d 39, 44 (1978) ("delay is not to be regarded as an overriding factor and . . . environmental factors . . . should be given determinative weight"), rev'd sub nom. Strycker's Bay Neighborhood Council, Inc. v. Karlen, 444 U.S. 223 (1980) (per curiam). The Supreme Court said that this was not a correct imterpretation of NEPA, which is a primarily procedural law. See note 245 supra. This Comment argues that CEQA, unlike NEPA, is a substantive law. Since CEQA defines feasible as "capable of being accomphished in a successful manner within a reasonable period of time," CAL. PUB. Res. CODE \$ 21061.1 (West 1977) (emphasis added), delay per se cannot be an impermissible consideration. Nevertheless, courts could conclude that delay occasioned only by the agency's failure to do things properly in the first placc is indeed an impermissible consideration.

299. See text accompanying note 366 infra for a discussion of the difficulty of drafting enforceable rules. Both courts and legislatures face these diffieulties.

300. The higher prices charged by the developer, however, might still be considered as a public cost, if that were appropriate. 
misplaced, the mdependent judgment standard is likely to yield a greater degree of environmental protection than the existing law.

The independent judgment standard of review should be more environmentally protective, because under existimg law substantive decisions are likely to be left exclusively to the agency. Simce the courts have not shown an inclination to make much use of the matter of law approach under existing law, there may be hittle real judicial review of substance. In contrast, the independent judgment standard invites the court to scrutinize the agency's findings of infeasibility. Amending the Act would allow citizens to invoke such judicial review if they beheve that the agency has not acted to protect the environment when it should have.

The proposed ainendment would not subject an agency's finding that an alternative is feasible to independent judgment review. The independent judgment standard should not be used to force agencies to approve projects, because the CEQA review process applies to projects whose approval is discretionary with the agency. ${ }^{301}$ Therefore, whenever a court used its independent judgment power and reversed an agency, the court would be acting to protect the environment in a way that is not likely under existing law. Furthermore, because the independent judgment standard invites the courts to review each case on its facts, cases in which the court refuses to overturn the agency are not likely to result in broadly antienvironmental holdings. ${ }^{302}$ Rather, such cases are likely to hold simply that on these facts the environment has been protected adequately. Thus, the independent judgment standard should provide a second chance for environmentally aware decisioninaking where the agency has neglected its duty to protect the environunent by failing to prefer feasible alternatives to proposed projects.

\section{$\mathrm{V}$ \\ THE INDEPENDENT JUdGMENT STANDARd APPLIEd UNDER MEPA: A FORECAST FOR CEQA}

This Comment now turns to examine experience with the independent judgment standard under the Michigan Environmental Protection $\mathrm{Act}^{303}$ (MEPA) in order to predict how Califorma courts might behave if they were einpowered to exercise their independent judginent

301. See note 262 supra.

302. Cf. Laurel Hills Homeowners Ass'n v. City Council, 83 Cal. App. 3d 515, 147 Cal. Rptr. 842 (1978) and Big Rock Mesas Property Owners Ass'n v. Board of Supervisors, 73 Cal. App. 3d 218, 139 Cal. Rptr. 445 (1977) (discussed at note 285 supra). In each of these cases, the court's ruling lowered the standards for agency findings in general, as opposed to sinply choosing to defer to the particular agency decision in question.

303. Мich. Comp. Laws ANN. $\$ \S 691.1201-.1207$ (West Supp. 1980-1981). 
in reviewing agency findings of infeasibility. The MEPA experience suggests that "independent judgment" courts may still be reluctant to overturn agency findings of infeasibility and to decide certain kimds of policy issues. Nevertheless, the MEPA cases suggest that courts are somewhat more likely to require the agency to reject a project for the reason that there is an environmentally superior alternative when they are empowered to apply their independent judgment, rather than a inore deferential standard of review.

MEPA requires courts to use their independent judgment to decide if an environmentally damaging project should be allowed to proceed. $^{304}$ Under MEPA, courts substantively review, im a de novo trial, the environmental merits of challenged public and private projects that have received agency approval. ${ }^{305}$ MEPA provides that if the plamtiff can prove that a project "is likely to pollute, impair or destroy . . . natural resources," the defendant may show, "by way of an affirmative defense, that there is no feasible and prudent alternative" to the project

304. Id. $\$ 691.1204(1)$. West Mich. Envt'l Action Council, Inc. v. Natural Resources Comm'n, 405 Mich. 741, 752-54, 275 N.W.2d 538, 541-42 (1979) (majority opinion) ("[w]hile we can understand a judge's reluctance to substitute his judgment for that of an agency with experience and expertise, the Michigan environmental protection act requires independent, de novo determinations by the courts"). Id. at $763,275 \mathrm{~N}$.W.2d at 546-47 (minority opinion) (concurring on this point). See MICH. CoMP. LAws ANN. $\$ \$ 691.1203(1), 691.1204(2)-(4), 691.1205$ (West Supp. 1980-1981).

Under MEPA, the independent judgment standard applies to factual deterininations as well. Superior Pub. Rights, Inc. v. Department of Natural Resources, 6 ENVT'L L. REP. 20435, 20437 (No. 73-15852-CE, Mich. Cir. Ct., Ingham County, Mar. 2, 1976), aff'd in relevant part, rev'd on other grounds, 80 Mich. App. 72, 263 N.W.2d 290 (1977). This Cominent has not proposed extending the independent judgment standard to review of the purely factual findings that underlie the agency's determination that an alternative is infeasible. This distinction, however, should not reduce the predictive value of the MEPA cases. This Cominent is primarily concerned with review of the agency's choice of goals, not with review of its factual findings. But see note 262 supra.

305. MEPA also provides for judicial review of private activities not requiring agency approval. See note 306 infra.

Note that the substantial evidence test apphed under CEQA requires an agency record on each question reviewed by the court. An inadequate record may result in a reinand, followed perhaps by a renewed court challenge. MEPA, on the other hand, provides for an independent judgment standard of review and a de novo scope of review. See West Micli. Env''1 Action Council, Inc. v. Natural Resources Comm'n, 405 Mich. 741, 752-54, 275 N.W.2d 538, $541-42$ (1979); Mich. Comp. LAwS ANN. $\$ \S 691.1203(1), 691.1204(2)-(4), 691.1205$ (West Supp. 1980-1981). MEPA courts may take additional evidence or remit the partics to administrative proceedings. See id. § 691.1204(2)-(3).

Thus, MEPA allows courts to consider alternatives and rule on their feasibility even when those measures have never been before an agency. CEQA, even amended to allow for an independent judgment standard, would confine the courts to reviewing what was presented to the agency. But this may be appropriate under California's legislative scheme: CEQA applies only to discretionary projects. CAL. PUB. RES. CODE $\$ \S 21002.1(\mathrm{c}), 21080(\mathrm{a})$ (West Supp. 1980). Under CEQA the agency may disapprove a project even though a court would find that all alternatives are infeasible. Thus it would be anomolous for a court to consider new alternatives, find them infeasible, and therefore approve the project, without giving the agency the opportunity to consider the new evidence. 
and that the project "is consistent with the promotion of the public health, safety and welfare in light of the state's paramount concern for the protection of its natural resources." 306 When this defense is asserted, then, MEPA actions pose basically the same question as is posed by the 1976 ainendments to CEQA: Is there an environmentally superior, feasible alternative to the project? ${ }^{307}$ The court must use its own

306. Мich. Comp. Laws ANn. \& 691.1203 (Sec. 3(1)) (West Supp. 1980-1981).

A MEPA action can be brought directly against a party who is polluting, impairing, or destroying natural resources as well as against a government agency for having granted a permit which allows such activity. Thus MEPA provides for an affirmative defense that there is no feasible and prudent alternative to the activity, rather than for court review of an agency finding that there is no such alternative. Because the comparable CEQA action is always an appeal from an agency decision, CEQA does not provide such an affirmative defense, but rather allows court review of agency findings of infeasibility.

307. While MEPA does not define the term "feasible and prudent," the Michigan Court of Appeals has construed the term. Wayne County Dept. of Health v. Olsonite Corp., 79 Mich. App. 668, 702-06, 263 N.W.2d 778, 796-97 (1977). Alternatives may be " "economically feasible even though . . . they are financially burdensome and affcet profit margins adversely. Nor does the concept of economic feasibility necessarily guarantee the continued existence of individual [companies]." " An alternative may be feasible even though a particular company that has lagged behind the rest of the industry is financially unable to carry it out. Id. at 703, 263 N.W.2d at 796-97 (quoting Industrial Union Dep't, AFL-CIO v. Hodgson, 499 F.2d 467, $477-78$ (D.C. Cir. 1974)).

In further construing the tern "feasible and prudent," the court rehed on Citizens to Preserve Overton Park, Inc. v. Volpe, 401 U.S. 402, 411-13 (1971). The Olsonite court held that in order for an alternative to be infeasible and imprudent under MEPA there must be "truly unusual factors" or costs of an "extraordinary magnitude." 79 Mich. App. at 704-06, 263 N.W.2d at 797, quoting 401 U.S. at 413. The court apparently rehed on the "paramount" importance of environmental considerations under MEPA. Compare Mich. CoMP. LAws ANN. \$691.1203(1) (West Supp. 1980-1981) ("the state's paramount concern for the protection of its natural resources") (emphasis added) with the language of Overton Park, 401 U.S. at 411 (the protection of parkland of paramount importance under the statute there in question) (emphasis added by the Olsonite court).

Insofar as MEPA requires "truly unusual factors" or "costs of extraordinary magnitude," it may require a greater degree of environmental protection than is inandated by CEQA. The $O I-$ sonite court supported its construction by noting that the Michigan Legislature had rejected an amendinent that would have required the determination of feasibility and prudence to be made " 'considering all relevant surrounding circunstances and factors." 79 Mich. App. at 705, 263 N.W.2d at 797. CEQA, however, defines feasible as "taking into account economic, cnvironmental, social, and technological factors." CAL. PUB. REs. CODE \& 21061.1 (West 1977).

On the other hand, CEQA, like MEPA, places a high value on environmental factors; e.g., "the long-term protection of the environment, consistent with the provision of a decent home and suitable living environment for every Californian, shall be the guiding criterion in public decisions." Id. $\$ 21001$ (d) (West Supp. 1980) (emphasis addcd) (the language requiring consistency with the provision of a decent home, etc., was added by Act of Sept. 22, 1979, ch. 947, § 5, 1979 Cal. Legis. Serv. 3597 (West)). Although this declaration is not contained in the sections addcd by the 1976 amendinents, those amendments did not change it, even though the legislature considered amending $\$ 21001$ (d) to require only that the environment be "given major consideration." A.B. 2679 as introduced, 1975-76 Reg. Sess. (Jan. 12, 1976).

Thus, the Olsonite court's definition of "feasible and prudent" probably restricts a Michigan agency's balancing of economic and social considerations against cnvironmental factors only to a somewhat greater degree than CEQA's definition restricts a California agency. In any event, the MEPA cases upon which this Comment rehes, in arguing that the independent judgment standard will in fact yield a greater degree of environmental protection, were almost all decided before Olsonite. 
independent judgment in deciding this substantive issue, even if the project has been granted whatever governmental permits it may require. ${ }^{308}$ Thus, under MEPA the court would not seem to be bound by an agency's determination of the goals an alternative must achieve in order to be feasible. ${ }^{309}$

However, despite this apparently greater freedom to enjoin projects because a superior alternative exists, MEPA cases ${ }^{310}$ suggest that "independent judgment" courts may be reluctant to require project proponents to make major changes in their projects. However, MEPA's approach is probably more likely than the approaches presently available under CEQA to impose additional costs on projects or require the use of alternatives that basically respect the project's major goals. MEPA is unabashedly substantive and requires the court to use its independent judgment. Furthermore, courts more activist than Michigan's might take even greater advantage of independent judgment power to reject a project because of the existence of an environmentally superior alternative.

The Michigan courts have been willing to impose public and private costs beyond those required by the agency, especially in order to prevent pollution. In Lakeland Property Owners v. Township of Northfield, ${ }^{311}$ for example, the court required a publicly owned sewage treatment plant to meet higher treatment standards than had been imposed by the State Water Resources Commission. In Irish v. Green ${ }^{312}$ the court required the developer of a subdivision that had already received local and state approval (1) to provide for central sewage and water facilities in order to prevent pollution from septic tanks, (2) to build an additional access road in order to preserve a scenic roadway, and (3) to install onsite erosion control neeasures. And in Eyde v. State ${ }^{313}$ the

308. See note 304 supra.

309. Under MEPA a court may decide that even though alternatives will not achieve the project's goals, the project should still be enjoined because it is not "cousistent with the promotion of the public health, safety, and welfare in light of the state's paramount concern for the protection of its natural resources." Mich. CoMp. LAws ANN. § 691.1203(1) (West Supp. 1980-1981). Thus, a MEPA court may independently examine the merits of a project; the court is not himited to using its independent judgment to decide what a project's goals really are (im order to determine whether or not an alternative is "successful").

310. Many of the MEPA cases are unreported trial court decisions. The author has relicd on a series of law review articles reporting ou MEPA litigation: Sax \& Conner, Michigan's Environmental Protection Act of 1970: A Progress Report, 70 Mich. L. Rev. 1003 (1972); Sax \& DiMento, Environmental Citizen Suits: Three Ycars' Experience Under the Michigan Environmental Protection Act, 4 Ecology L.Q. 1 (1974); Haynes, Michigan's Environmental Protection Act in its Sixth Year: Substantive Environmental Law from Citizen Suits, 53 J. URB. L. 589 (1976) (reprinted in revised form in 6 ENVT'L L. REP. 50067 (1976)).

311. 3 Envir. ReP.-Cases 1893 (No. 1453, Mich. Cir. Ct., Livingston County, Feb. 29, 1972).

312. 4 Envir. Rep.-CAses 1403 (No. 162-3, Mich. Cir. Ct., Emmet County, July 15, 1972).

313. 82 Mich. App. 531, 267 N.W.2d 442 (1978). 
court required the defendants to spend an additional $\$ 67,000$ for reforestation and restoration of a sewer right-of-way.

Cases decided under MERA, the Minnesota Environmental Rights Act, ${ }^{314}$ which was modelled after MEPA," ${ }^{15}$ suggest that "independent judgment" courts may go so far as to enjoin agency-approved projects because there is a superior offsite alternative. ${ }^{316}$ In Minnesota Public Interest Research Group v. White Bear Rod and Gun $C l u b,,^{317}$ the court enjomed the operation of a gun club, which had secured a permit from the local government. The court found that the club made excessive noise in a quiet neighborhood and that the lead shot falling into a nearby marsh threatened to poison waterfowl. ${ }^{318}$ The evidence suggested that the approved site was the worst possible location for a trapshootmg facility. ${ }^{319}$ An abandoned gravel pit, for instance, would have been a superior location, as it would contain both the noise and the spent shot. ${ }^{320}$

314. MinN. STat. ANN. $\$ \S 116$ B.01-.13 (West 1977).

315. People for Envt'l Enlightenment and Responsibility (PEER), Inc. v. Minnesota Envt'l Qual. Council, 266 N.W.2d 858, 866 n.6 (Minn. 1978) (MERA based on MEPA).

316. MERA, like MEPA, defines the term "feasible" somewhat differently than does CEQA. In County of Freeborn v. Bryson, 309 Minn. 178, 186-87, 243 N.W.2d 316, 320-21 (1976), the Minnesota Supreme Court adopted the Overton Park definition of "feasible and prudent." In Overton Park, the U.S. Supreme Court construed a statute prohibiting the construction of highways through parks unless there is no feasible and prudent alternative. The Court held that alternatives were not infeasible and imprudent unless there were "truly unusual factors" or costs of "extraordinary magnitude." See Citizens to Preserve Overton Park v. Volpe, 401 U.S. 402, 411-13 (1971). MEPA has also been construed to embody the Overton Park definition of feasible and prudent. See note 307 supra.

317. 257 N.W.2d 762 (Minn. 1977).

318. Although the club had secured a permit, according to the local government's attorney the permit had become void because the noise level violated the permit conditions. 257 N.W.2d at 765-66, 765 n.2. Thus the Gun Club case did not actually overturn an agency's approval. However, the court refused to remand the case to the local government because MERA denies the local government the authority to permit pollution. Id. at 783 . This suggests that the court would still have enjomed the gun club even if the local government had issued a permit authorizing the noise and the firmg of lead shot into the waterfowl marsh. (The local government apparently had not even considered the lead shot issue. See text accompanying note 323 infra.)

319. 257 N.W.2d at 778.

320. Id. at 766 n.3.

See also People for Envt'l Enlightenment and Responsibility (PEER), Inc. v. Minnesota Envt'l Qual. Council, 266 N.W.2d 858 (1978), in which the court ordered the Council to rescind its approval of an "environmentally damaging" powerline route because of the existence of a feasible route paralleling an existing powerline. Id. at 862,864 .

However, $P E E R$ is of minimal predictive value for a variety of reasons. First, the court found a strong preference for routing power lines along existing rights of way im the Power Plant Siting Act. Id. at 868. See MinN. STAT. ANN. \$\$ 116C.51-69 (West 1977 \& Supp. 1980). However, the court also found this pohcy of nonproliferation embodied in the feasible and prudent alternative requirement of MERA, id. $\S 116 \mathrm{~B} .04$. 266 N.W.2d at 868, 874. Thus one cannot tell whether the PEER court was enforcing a legislative commitunent to the primciple of nonproliferation or exercising its independent judgunent under MERA. Second, the utility had origimally proposed to follow the route the court ultimately preferred. See id. at 862 . Finally, the court apparently relied on a provision of MERA, not found in either MEPA or CEQA, that provides 
The above cases indicate a willingness to prefer environmentally superior alternatives and override agency decisions. But they do not demonstrate how "independent judgment" courts would respond if agencies or project proponents seriously attempted to prove that alternatives were infeasible. In the Gun Club case and in Irish the defendants did not attempt to estabhish the affirmative defense that there was no feasible and prndent alternative. ${ }^{321}$ Although the defendants im Lakeland did assert such an affirmative defense, the court found that the defendants had not introduced a sufficient quantum of specific evidence that the alternative proposed by the court was infeasible. ${ }^{322}$

Furthermore, in the Gun Club case the local agency apparently did not even consider alternatives designed to avoid waterfowl poisoning, since the impact of the project was not examined until after the permit had been granted. ${ }^{323}$ Thus, the agency presumably had made no decision that alternatives were infeasible. ${ }^{324}$ In contrast, CEQA's EIR procedure ensures agency consideration of impacts and alternatives prior to a decision to approve a project. And before approving a project a Califormia agency must exphicitly find that specific factors make superior alternatives infeasible. ${ }^{325}$ Unlike the courts in these MEPA and MERA cases, a Califorma court reviewing an agency approval under CEQA would be presented with specific arguinents as to why alternatives previously studied by the agency are infeasible. This fact might tend to imcrease judicial deference for the agency decision in California. The EIR may well convince a court that the agency has considered

that "[e]conomic considerations alone shall not constitute a defense" to a cause of action under MERA. Minn. STAT. ANN. $\$ 116$ B.04 (West 1977). The Council chose the route it did in order to avoid the condemnation of a number of homes, 266 N.W.2d at 869 , even though that route impacted on a lake and a woods. Id. at 867 . The court found that so long as the homeowners could be fully compensated for the loss of their homes (the loss thus being purely economic) there was no legally cognizable reason for allowing any damage to the lake and woods. See id. at $863,864,869$, 870, 874. Since CEQA permits agencies to consider economic values, PEER does not necessarily help to predict how California courts would decide a similar case if they were authorized to use their independent judgment.

321. See note 306 and accompanying text supra.

322. 3 ENVIR. REP.-CASES at 1902 . The court also noted that the defendants had failed to consider factors the court thought relevant to the decision they were making. Note that this omission would result in a remand to the agency under CEQA.

See also People for Envt'1 Enlightenment and Responsibility (PEER), Inc. v. Minnesota Envt'l Qual. Council, 266 N.W.2d 858 (Minn. 1978), in which the court felt it could not consider the only factor supporting infeasibility (home condemnation) because of the controlling statute. See note 320 supra.

323. See 257 N.W.2d at 765 n.3.

324. If it had better understood the project's impact, the local government might not have granted the gun club a permit. Early consideration of impacts is one of the advantages of the EIR procedure.

325. See Cal. Pub. Res. Code $\$ 21081$ (West 1977) (quoted at note 34 supra). 
the relevant factors and therefore has reached a correct result. ${ }^{326}$ On the other hand, since the EIR clearly sets out a number of alternatives, the presence of an EIR might encourage the court to find that there are indeed feasible alternatives to the proposed project.

Only a few reported MEPA cases have involved agencies that have atteinpted to prove alternatives infeasible. One of those, Superior Public Rights, Inc. v. Department of Natural Resources, ${ }^{327}$ suggests that courts may be reluctant to reverse agency determinations that there is no feasible and prudent alternative to a proposed project. In Superior Public Rights the plaintiff challenged a Department of Natural Resources permit for a power plant's cooling water intake, discharge pipes, and coal dock. The court applied the independent judgment standard, ${ }^{328}$ but it agreed with the agency that there was "no feasible and prudent alternative to the proposed pipe construction." 329 This is in contrast to the cases discussed above that were won by environmentalists when defendants made no serious efforts to show that the proposed alternatives were infeasible. Indeed, in this case, the court even adopted part of the agency's findings. ${ }^{330}$

One reason why courts may be reluctant to reverse an agency's determination of infeasibility is that requiring the agency to prefer a previously rejected alternative inay totally frustrate one of the agency's goals. Under CEQA California courts would always have agency findings of infeasibility to review. These findings will have articulated the agency's goals. Thus California courts might be reluetant to enjoin proposed projects if CEQA were amended to provide for an independent judginent standard of review. Nevertheless, if authorized to exercise their independent judginent, California courts should still be willing to overturn an agency finding of infeasibility where serious er-

326. Cf. Jordan, supra note 173 , at 747 (discussing the "hard look doctrine" under which courts show greater deference to agency decisions reached after more careful consideration).

327. 6 Envt'L L. Rep. 20435 (No. 73-15852-CE, Mich. Cir. Ct., Ingham County, Mar. 2, 1976), aff' in relevant part, rev'd on other grounds, 80 Mich. App. 72, 263 N.W.2d 290 (1977).

328. This case was first to hold that courts must exercise their independent judgment when reviewing agency decisions claimed to violate MEPA. The court held that MEPA requires courts to exercise their independent judgment even when the decision of an "expert" agency is at issue.

See 6 ENVT'L L. REP. at 20437.

329. Id. at 20438.

330. Id.

A reluctance to enjoin such a major project as the power plant expansion may have been another factor that made the Superior Public Rights court more willing to defer to the agency decision. Haynes, supra note 310 , at 618 n.110, describes an unreported portion of the opinion noting the importance of balancing economic with environmental considerations. On the other hand, the court stated that "the record does not justify the sweeping conclusion that granting an injunction would create inassive adverse economic impacts." 6 ENVT'L L. REP. at 20437.

Cf. Sax \& DiMento, supra note 310, at 5-6, n.18 (for the most part MEPA cases have not been brought against the wajor Michigan economic interests). 
rors of judgment in the agency's balancing of costs and benefits underlie that finding.

Irish v. Green ${ }^{331}$ further suggests that courts may be reluctant to redefine a project's goals. While the court in Irish imposed measures to prevent water pollution and the destruction of a scenic roadway, it was unwilling even to consider whether the defendant should have been required to construct a "cluster" type development rather than the traditional subdivision it had proposed. The court dismissed a count of the coinplaint that sought to require a clustered alternative, statimg that "[t]he defendant developer's project either violates the act or does not. Plaintiffs have no right to invade property rights to the extent of dictating alternative developinents which may or may not have market appeal."332 However, this statement does not appear to be a correct interpretation of MEPA. MEPA requires the defendant to prove the infeasibility of alternatives once the plamtiff has shown that natural resources are likely to be impaired or destroyed. ${ }^{333}$ Because "trees per se are natural resources," 334 so long as the clustered development would have resulted in the destruction of significantly fewer trees, the burden of proving the infeasibility of the clustered alternative should have been on the developer. The court's reluctance to consider the possible superiority of the clustered alternative thus was grounded, not upon the Act, but upon the notion that courts simply do not decide such issues as whether a developer should proceed with a different kind of developinent. The court was unwilling to consider the environmental desirability of a project that did not fulfill the goals of the approved project. It was unwilling to decide issues of planning policy. ${ }^{335}$

Thus, the limiting factor on a court's willingness to frustrate an agency-defined goal niay be its conception of what kinds of issues courts decide. ${ }^{336}$ Even courts authorized to use their independent judg-

331. 4 Envir. ReP.-Cases 1403 (No. 162-3, Mich. Cir. Ct., Emmet County, July 15, 1972). See text accompanying note 312 supra.

332. 4 ENVIR. REP.-CASES at 1403.

333. See Mich. Comp. LAws ANN. §691.1203 (Sec. 3(1)) (West Supp. 1980-1981); text accompanymg note 306 supra.

334. 4 ENVIR. REP.-CASES at 1405.

335. Interestingly, the Irish court avoided deciding the same issue that the Laurel Hills court avoided deciding - whether a developer should be forced to construct a clustered development rather than a single-family subdivision. In this respect the result under the independent judgment standard was the same as the result under the present California Act.

336. Courts are used to deciding nuisance cases and are familiar with traditional forms of air and water pollution. Therefore they might more readily intervene in cases where offsite pollution would be caused directly by the project than in cases where the alleged harn would be caused more indirectly or would involve a more generalized form of environmental degradation, such as loss of open-space or wildlife habitat. See text accompanying notes 311-12 and 331-32 supra. Irish v. Green, 4 Envir. Rep.-Cases 1403 (No. 162-3, Mich. Cir. Ct., Emmet County, July 15, 1972), refused to consider an alternative that would have reduced the general environmental im- 
ment may be unwilling to decide whether preserving a marshland is more important than increasing local tax revenues, whether preserving open space is more important than fulfilling a demand for hillside hoines, ${ }^{337}$ or whether breathing cleaner air is more important than maintaining the character of the community. ${ }^{338}$

Courts are likely to view basic questions about the kind of society and environment we are going to hive in as best left to the legislature in the absence of a constitutional requirement, and as best left to local governments and other "politically responsible" agencies in the absence of a clear directive from the legislature. ${ }^{339}$ Where policy goals conflict, courts may be reluctant to intrude in the absence of exphicit guidance from the legislature as to which pohicy to prefer. However, some courts might use their independent judgment power in a more activist fashion. They might be willing to decide, on the basis of the general directives contained in an act like MEPA, the issue of planning policy avoided by the Irish court. They might be willing to reject a highly particularized goal, e.g., building condominiums im a certain neighborhood, so long as the basic purposes of the project were achieved, e.g., providing middle-income housing in a region. ${ }^{340}$ However, there are policy questions that are probably too fundamentally political for courts to be willing to decide. Even a relatively activist court would be very unlikely to decide that a whole region should stabilize its population, unless the growth in population would exceed some legislatively set limit or cause some other legislatively determined standard to be violated. ${ }^{341}$ Thus, faced directly witl a question such as

pact of the project, while it imposed requirements designed to prevent onsite and offsite water pollution and to protect a specific scenic resource.

Because courts are experienced in deciding questions of motivation and intent, under the independent judgment standard they might be willing to reject agency goals which they suspected were advanced merely for the purpose of proving an alternative infeasible and not because they represented genuinely important goals of the agency. Thus a court might be willing to ignore a goal of providing increased consumer purchasing power in an already affuent area. $C f$. note 256 and acconipanying text supra (this goal not a compelling consideration), and text accoinpanying note 107 supra (this apparently was a goal of the Laurel Hills developinent). See text accompanying notes 232-34 supra (under existing law, courts should find an abuse of discretion where agencies adopt sham goals and should disregard sham goals).

337. Cf. discussion of Hayward's rezoning of the Soda property in text accoinpanying notes 151-53 supra.

338. Cf. discussion of Livermore's Master ElR in text accompanying notes 145-49 supra.

339. See Comment, The Role of the Judiciary in the Confrontation with the Problems of Environmental Quality, 17 U.C.L.A. L. REV. 1070, 1074 (1970) (disinclination of judges to make substantive determinations requiring a "partial change of life style").

Cf. discussion of PEER, 266 N.W.2d 858 (1978), at note 320 supra (court unanaged to find a specific legislative directive).

340. See note 276 and text accompanying notes 113-15 supra.

341. And courts are unlikely to attempt to put a halt to population growth just because that would cause air pollution standards, for example, to be violated. 
whether the Monterey area should continue to grow, courts will almost certainly defer to local governments or other government agencies that have the power to limit growth. Courts are unlikely to act unless the state sets definite limits to the area's growth by means of a specific statute such as the Coastal Act. ${ }^{342}$ The more pohtical the pohicy issue involved, the more likely it is that the courts will want to rely on legislative or constitutional guidance. ${ }^{343}$

Thus, there are likely to be limits on the kinds of decisions courts are willing to inake, regardless of whether they are operating under the substantial evidence or independent judgment standard. Still, the MEPA cases indicate that courts authorized to use their independent judgment at least will be more willing to impose additional environmental protection costs on projects than is likely to be the case under the present California Act. In the cases examined, courts imposed additional financial costs on public and private projects. Courts should, however, also be willing to protect the environment by reducing the scope of projects, thus imposing costs in the form of foregone benefits. Although they might tend to defer to agency findings of infeasibility, California courts authorized to use their independent judgment should still reverse agencies if those findings are based on serious or obvious errors of judgment in balancing costs and benefits. And Califorma's courts may be more "activist" in protecting the environment than Michigan's. In suin, if CEQA were amended to provide for an independent judgment standard, effective review of substantive agency decisions should be inore frequent than it is at present. Independent judginent review should provide a second chance for environmentally sensitive decisionmaking.

\section{VI}

\section{The Legitimacy OF INDEPENDENT Judgment Review}

This Comment has outlined a proposal to expand substantive judicial enforceinent of CEQA by adopting an independent judgment standard of review for agency findings of infeasibility. Experience with MEPA and MERA, which provide for de novo trial court consideration of projects that are challenged as environmentally unsound, justifies a guarded optimism about the efficacy of independent judgment review.

342. Cf. discussion of the PUC's approval of an expanded water supply for the Monterey Peninsula in text accompanying notes 154-63 supra.

343. Appellate courts might be inore willing than trial courts to decide policy issues. However, under the imdependent judgment standard the outcome of a case is likely to depend on its particular facts, as that standard encourages case-by-case balancing. Thus, it might be difficult for the appellate courts to guide trial courts by laying down broadly applicable rules of law that would tell trial courts which policy they should generally prefer. See also text accompanying notc 366 infra. 
The independent judgment approach should yield a greater degree of environmental protection than substantial evidence, procedural, or inatter of law review. It is also a more flexible and candid approach than the others. But, it might be objected that the broader mandate would give the courts too much power over matters of planning policy. The judiciary is not "politically responsible" as the executive, legislature, and, indeed, local governments are. Moreover, judges are not "expert" in the fields of regional planning or environmental protection. Yet CEQA has imposed environmental responsibilities, procedural and substantive, upon all local and statewide agencies. Who will ensure that these agencies fulfill their responsibilities, if not the courts?

As an alternative to judicial review of administrative findings of infeasibility, review powers might be vested in an expert, politically responsible statewide agency, such as the Resources Agency or the Office of Planning and Research (OPR). ${ }^{344}$ Presently, no state agency routinely looks at findings of infeasibility or at decisions to approve projects made by other state and local agencies at the conclusion of the EIR procedure. ${ }^{345}$ Expert state agency involveinent is limited to coinmenting on draft EIR's. Agency decisions which are thought to violate CEQA inust be detected by private citizens and generally inust be challenged by private lawsuits. ${ }^{346}$ Instead, the Resources Agency or OPR might routinely review agency decisions to approve projects due to the infeasibility of alternatives. Then OPR or the Resources Agency might challenge environmentally unjustifiable decisions in one of two ways. The first possibility would be for the Resources Agency to reweigh the evidence and overturn findings of infeasibility it found unjustified. The overruled agency would have a right of appeal to the courts, but the Resources Agency determination would be reviewed under the deferential substantial evidence test. The other possibility would be to grant the Resources Agency the power to seek judicial review of agency findings of infeasibility, with the court enploying the independent judginent standard of review when such a suit was brought by the Resources Agency. The latter might actually be possible under present law.

Government Code sections 12600-12612 authorize the state Attorney General to initiate a MEPA-type court action alleging impairment,

344. See Robie, supra note 188, at 434 (proposal that federal Council on Environmental Quality review agency decisions for compliance with policies of NEPA so that burden of enforcing compliance will not fall solely on private citizens).

Because the Resources Agency supervises a number of operating departments, it might be put in the position of laving to review its own findings of infeasibility. OPR would not share this debility: it functions as a planning and coordinating agency only.

345. Interview with Nornıan Hill, California Resources Agency, March 9, 1979.

346. Id 
destruction, or pollution of natural resources. These sections provide for an affirmative defense that there is no more feasible and prudent alternative to the conduct complamed of. ${ }^{347}$ Thus, the state might use these sections to challenge what it believed to be unjustified findings of infeasibility. The state would allege that the approved project threatened natural resources and the agency would have to defend on the grounds that there was no feasible alternative. These code sections should be construed to authorize an imdependent judgment standard of review. The statute is modelled on MEPA: ${ }^{348}$ It specifies that the court shall not approve any conduct which will impair, pollute, or destroy natural resources unless the conduct is consistent with the protection of the public health, safety, or welfare. ${ }^{349}$ Furthermore, the statute allows the courts to consider evidence not before the agency. ${ }^{350}$ These factors indicate that the independent judgment standard of review was imtended for actions brought under these Government Code provisions. ${ }^{351}$

However, these Government Code sections have rarely been used for any purpose. ${ }^{352}$ This indicates a major weakness with relying on a "politically responsible" agency to challenge findings of infeasibility made by other agencies. If the politicians im charge of setting policy for the reviewing agency are not staunch supporters of environmental pro-

347. CAL. Gov'T CODE $\S \S 12600-12612$ (West Supp. 1979) (see especially $\S \S 12607,12608$ ).

348. DiMento, Citizen Environmental Legislation in the States: An Overview, 53 J. URB. L. 413,415 n.6 (1976).

349. CAL. Gov'T CODE $\S \S 12612$ (b), 12607, 12608 (West Supp. 1979).

350. Id. $\S 12612$ (c). The substantial eyidence test requires the court to review the record before the agency to see if there was substantial evidence to support the ageucy's decision. Thus the substantial evidence test cannot be applied to evidence that was not before the agency. The independent judgment standard, on the other hand, can be used in scrutinizing evidence that was not before the agency. See note 305 supra (MEPA allows the courts to review evidence not before the agency).

351. It might be objected that section 12611, unlike MEPA, requires that the challenged conduct be reviewed by any agency having authority to determine its legality, before the court decides the case. CAl. Gov't CODE § 12611(a) (West Supp. 1979). Cf. Mich. Comp. Laws AnN. § 691.1204 (Sec. 4(2)) (West Supp. 1980-1981) ("the court may remit the parties to such [administrative] proceedings" (einphasis added)). This provision for agency review might be thought to invoke the substantial evidence standard, particularly since CEQA, the arguably more specific statute, provides for the use of the substantial evidence test. However, CEQA provides for that standard only in actions based on noncompliance with CEQA. CAL. PUB. REs. CODE $\$ \S 21168$, 21168.5 (West 1977) (discussed in text accompanying notes 49-53 supra). But an action brought under the Government Code sections, challenging an agency's approval of a project based on the infeasibility of alternatives, would not be based on noucompliance with CEQA; rather, it would be based on a claim that the agency's conduct would pollute, impair, or destroy natural resources im violation of the policies of the Government Code sections. Thus, on balance, the Government Code sections do seem to provide for an independeut judgineut standard of review.

352. DiMento, supra note 348 , at $434-35$. 
tection few, if any, such actions would be brought. ${ }^{353}$ Moreover, a public agency with a limited staff and budget cannot oversee planning decisions as thoroughly as interested local citizens can. Therefore, some other way im which agency findings of infeasibility might successfully be challenged is needed, if the decision as to how much environmental protection we ought to enjoy is not to be left exclusively to state and local agencies that often pursue antienvironmental goals. ${ }^{354}$

Even if a statewide expert agency is unlikely to review planning decisions adequately, it might be argued that the local agencies themselves are inore "politically responsible" than the judiciary and deserve the deference afforded, e.g., by the substantial evidence test. ${ }^{355}$ If citizens are unhappy with the quality of environmental decisions made by government officials, they are expected to express their displeasure via the ballot box. ${ }^{356}$ Election campaigns, however, seldom turn on environmental issues. Furthermore, insofar as CEQA attempts to enforce statewide environmental policies on local agencies, the fact that local officials are responsible only to their own constituents argues in favor of an mcreased role for the courts, not against it. As discussed above, local agencies often pursue local goals with insufficient regard for environmental protection or regional planning policies. ${ }^{357}$ Even statewide agencies may be expected to show more concern for the particular missions they were created to accomphish than for legislatively set environmental planning policies. It is doubtful, then, that agencies are so politically responsible regarding CEQA that they should be left to occupy the field alone.

Another reason advanced for employing a deferential standard of review is that it leaves the decision to an "expert" agency. ${ }^{358}$ But the decisionmakers implementing CEQA are generally not expert in the field of environmental protection. ${ }^{359}$ Rather, they are often indifferent

353. Id.

For example, the staff of the California Attorney General's Office has charged that Attorney General Deukmejian has abdicated his duties "as legal protector of California's natural resources." San Francisco Chronicle, Dec. 11, 1979, at 18, col. 1. Deputy Attorney General Alexander T. Henson resigned, noting that "[n]० new proposal to appear in [environmental] litigation has [been] approved since last May. ..." Id, col. 6 .

354. See note 62 and text acconpanying notes 113-15 supra.

355. Cf. Comment, supra note 339, at 1074-77 (courts should not make substantive policy choices best made by representative bodies of government).

356. See People v. County of Kern, 39 Cal. App. 3d 830, 842, 115 Cal. Rptr. 67, 75 (1974); Bill Analysis of A.B. 2679, supra note 15, at 5 (findings requirenient improves public accountability by requiring decisionmaking body to take definite stand on environmental issues).

357. See note 62 and text accompanying notes 112-15 supra.

358. Courts traditionally have deferred to the expertise of specialized agencies in the application of law to fact. See, e.g., K. Davis, supra note $55, \S 30.03$.

359. Cf. Jordan, supra note 173 , at 744 (the federal agencies that prepare environmental impact statements are not environmentally expert). 
or opposed to the environmental protection purposes of CEQA. ${ }^{360}$ Courts are unlikely to share a consistently antienvironmental bias, and so are better able to ensure that agencies comply with the legislature's environmental policies, as expressed in CEQA. ${ }^{361}$ The independent judginent standard would ensure review by a second, and generally neutral, decisionmaker. ${ }^{362}$ This should result in greater environmental protection overall.

A final point about the legitimacy of judicial supervision of more "politically responsible" bodies is that the legislature has authorized the courts to review environmental decisions by enacting CEQA and these Government Code sections. The legislature, by approving the independent judgment proposal, again would be expressly authorizing judicial review. Furthermore, the substantive duties of CEQA have also been enacted by the legislature. Thus, even under an independent judgment approach, courts would be atteinpting to implement legislatively established policy, rather than simply substituting their own views for the agencies'. ${ }^{363}$

The MEPA experience suggests that courts nnay be relatively restrained in their response to pleas for intervention in planning decisions. But if they become overly intrusive the legislature remains free to amend the Act. The legislature might control the courts in one of several ways. It might pass legislation overriding specific court decisions, it might except certain kinds of projects from CEQA's substantive requirements or from independent judgment review, or it might set more specific guidelines to govern the application of CEQA to particular kinds of situations.

The legislature no doubt spoke as clearly as it could when it enacted CEQA. ${ }^{364}$ It had to speak in general terms, both because CEQA is a general statute intended to cover multifarious situations and because CEQA is a product of legislative compromise. The legislature, however, inay be able to draft more specific guidelines to cover particu-

360. Cf. Note, Substantive Review Under the National Environmental Policy Act: EDF v. Corps of Engineers, 3 ECOLOGY L.Q. 173, 186-87 (1973) (federal agencies' lack of environmental expertise and bias in favor of their own policies argues for less judicial deference to their decisions on environmental issues; therefore, substantive review ought to be available under NEPA).

361. See DiMento, supra note 348, at 420-21; Bryden, Environmental Rights in Theory and Practice, 62 MinN. L. Rev. 163, 170-73 (1978). Cf. id. at 217 n.378 (state court judges often make anti-environmental decisions).

362. Cf. Jordan, supra note 173, at 757 (environmentalists would prefer court decisions to agency decisions).

363. See Sax \& Conner, supra note 310, at 1065 (for the courts to implement legislatively set policy against the agency is not to usurp legislative prerogatives, but to enforce the legislative prograin in particular instances).

364. Cf. Ray v. Mason County Drain Comm'r, 393 Micl. 294, 306-07, 224 N.W.2d 883, 888 (1975) ("the Legislature spoke as precisely as the subject matter permit[ted]" when it enacted MEPA). 
lar kinds of problems. Indeed, as suggested above, courts may be reluctant to enjoin environmentally damaging projects $\mathrm{m}$ the absence of more specific statutory directives. ${ }^{365}$ However, im many cases it may be difficult for the legislature to draft precise, enforceable rules to govern agency conduct. It is easy to say, for example, that environmental losses are often permanent, while economic gams are frequently transitory-but how does one draft an enforceable rule to require agencies to take account of that fact as they weigh the benefits and harms of a proposed project? ${ }^{366}$ Thus, the legislature may be unable to, or prefer not to, draft more particularized guidelines. The legislature may legitimately prefer to state its overall pohicy goals and let the courts apply thein in case-by-case adjudication.

If the legislature were to routinely overrule court decisions or were to exempt whole classes of projects from CEQA's requirements or imdependent judgment review, the whole purpose of amending the Act to provide independent judgment review would be undermined. However, such an extensive backlash is unlikely so long as courts are reluctant to seriously frustrate major agency goals in the absence of more specific standards. ${ }^{367}$

The legislature cannot fully secure comphance with CEQA in dayto-day agency decisionmaking because of its mability to craft suffciently specific standards. Nor can statewide expert agencies be relied upon to oversee agency compliance with CEQA. Authority for the Attorney General to bring environmental actions at the behest of mdividuals or of a state agency now exists, but it has not been exercised frequently, nor is it likely to be employed with sufficient frequency to fulfill CEQA's policies. Thus, enforcement of the statewide, legislatively determined policies of CEQA can best be secured by allowing citizens to seek independent judgment court review of agency determinations of infeasibility. And the courts, controlled or directed as necessary by new legislation, can legitimately enforce the legislative mandate on a case-by-case basis.

365. See note 320 and text accompanying note 341 supra.

366. Even without very specific standards, however, courts may be more willing to enforce vague legislation strictly where the statute governs a narrower range of agency decisions. See, e.g., section 4(f) of the Department of Transportation Act of 1966, as amended, 49 U.S.C. \& 1653(f) (1976) (the Secretary of Transportation shall not approve a project requiring use of park land unless "there is no feasible and prudent alternative to the use of such land"), enforced in Citizens to Preserve Overton Park, Inc. v. Volpe, 401 U.S. 402, $411-13$ (1971). The Overton Park case is discussed in note 316 supra. Note, however, that under MEPA and MERA, courts have applied the strict Overton Park standard of feasibility to review of the broad range of activities covered by those statutes. See notes 307 and 316 supra.

367. See generally Sax \& DiMento, supra note 310, at 5-6, n.19 (If MEPA cases had been won against inajor economic interests, einasculating legislation might have resulted). The threat of emasculating legislation may discourage the courts froun frustrating major agency goals. 


\section{CONCLUSION}

CEQA announces a policy of environmental protection that, at present, may be too easily ignored or undermined, largely because courts review agency decisions deferentially. The judiciary might use procedural remands or rules of law to review more searchingly agency findings that environmentally superior alternatives are infeasible. But these techniques present disadvantages, including a lack of flexibility where there is a need to take account of highly individualized circumstances. Nevertheless, courts could develop a number of procedural rules and rules of law that would afford greater environmental protection than the substantial evidence test is ever likely to.

Allowing private citizens to invoke the independent judgment standard of review in suits challenging agency findings of infeasibility would be a better means of providing a greater degree of environmental protection. Courts authorized to use their independent judgment could be expected to provide a second opportunity for environmentally sensitive decisionmaking. The courts could use their independent judgunent power to short-circuit agency atteinpts to manipulate the definition of a project's goals so as to make alternatives seem infeasible. Courts could also impose an additional increment of environmental protection costs (in the form of increased public or private expenditures or in the form of decreased public benefits) where they found that an agency had not required reasonable environmental protection measures to be taken. The example of MEPA and MERA litigation suggests that courts would rarely use their power to frustrate an important agency goal or to decide inajor policy questions. In cases where they did use their power in that way, the legislature would be free to overturn court decisions it felt went too far. On the other hand, because of the courts' reluctance to decide inajor environmental pohcy questions in the absence of specific statutory guidance, challenges to agency findings of infeasibility under the general provisions of CEQA should not be expected to make a vast improvenent in environmental quality. In solne areas, more specific legislation, setting explicit standards for particular agency actions, could be expected to force agencies to pursue more environmentally sound goals. As a general rule, however, the courts will best serve the legislative policy of promoting less harmful project alternatives if they are instructed to exercise their independent judgment in evaluating the alternatives.

Joel T. Perlstein*

* B.A. 1976, University of Chicago; J.D. 1980, Boalt Hall School of Law, University of California, Berkeley. 